\title{
Grieving prison death
}

Ti Lamusse

A thesis submitted in fulfilment of the requirements for the degree of Master of Arts in Sociology, the University of Auckland, 2017. 


\begin{abstract}
The prison is a repressive apparatus that underpins settler-colonial capitalism in Aotearoa, a site for the collection and containment of bodies abjected from the social formation. When a person dies in prison, their death can expose some of the worst excesses of the current mode of production and immiseration. This thesis grapples with what it means to grieve the death of the prisoner. Interrogating 108 coroners' findings into deaths in New Zealand prisons, it outlines the material conditions of confinement leading to people's deaths, as well as the state's attempt to come to terms with these deaths. Framed within the work of Judith Butler, the Department of Corrections enacts routine practices upon the bodies of the deceased that constitute dehumanising norms. Alongside the vilification and abjection of the prisoner, these norms establish that the prisoner is not recognisable as fully human. As a result of a security context that exacerbates the vulnerability of prisoners for the benefit of those worthy of protection, prisoners are placed in positions of extreme precarity. The material practices that reinforce the inhumanity of prisoners and increase their level of precarity establish, before the prisoner's death, that the prisoner's life is not a life worthy of living. Grieving the death of the prisoner requires the recognition of prisoners as fully human, which is not possible within a normative context that necessitates their dehumanisation. Thus, to grieve the death of the prisoner, there must be a material transformation of these dehumanising practices, and the normative social conditions in which they are necessitated. As those normative practices, and the prison itself, are so entrenched in settler-colonial capitalism, mourning the death of the prisoner requires much more than the coroners can conceive.
\end{abstract}




\section{Acknowledgements}

As with all work, this work is not mine alone. Although I typed these pages, my ability to do so is due to countless others. Jean and Bernard Lamusse, my parents, without your love and support this would not have been finished. To my friends and comrades in NPIP/PAPA, including Aaliyah, Alex, Dani, Emma, Emmy, Kate, Kī, Max, Sophie B, Sophie M, Sophie W, and many others, this thesis comes out of your hard work fighting for a more just world. Rhian Hartmann, you have shown time after time the importance of friendship and your feedback was vital. I have been honoured to have had several current and former prisoners come into my life, as both advocates and friends. Ashley, Laken, Hone, Mark, and Josh, you have taught me so much about New Zealand prisons and your strength continues to inspire me. I feel truly lucky to have had support from some incredible scholars at the University of Auckland Sociology Department and elsewhere. Campbell Jones, your academic rigour astounds me and I will always be thankful to you for your ruthless commitment to improving my writing and scholarship. Alice Mills, thank you so much for sitting down with me in the early days of the project, and for helping me to orient my thought. Elizabeth Stanley, from Victoria University in Wellington, you introduced me to a formidable group of abolitionist scholars and I am truly grateful for that. Phil Scraton, from Queen's University Belfast, I am astounded by your generosity and I feel fortunate to have met with you on your two most recent trips to Aotearoa. Your guidance at the beginning of this project was invaluable and your persistence in the face of injustice is remarkable. Tracey McIntosh, your consistent willingness to help me both academically and with prisoner organising has meant so much to me. You continue to show us all what it means to be a critical public intellectual in Aotearoa. Finally, I could not have hoped for a better supervisor than Carisa Showden. You necessarily challenged me but also gave me the support I needed to complete this. I hope you know how much myself and all your students appreciate all the extra emotional support you give us. Thank you for all this and much more. 


\section{Contents}

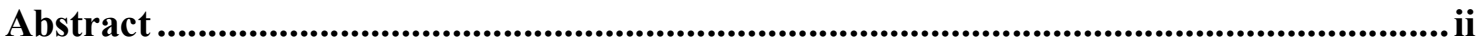

Acknowledgements................................................................................................................. iii

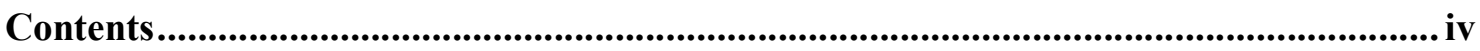

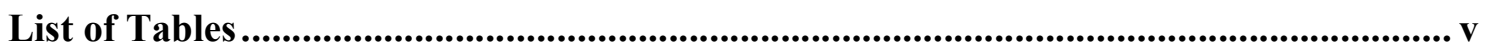

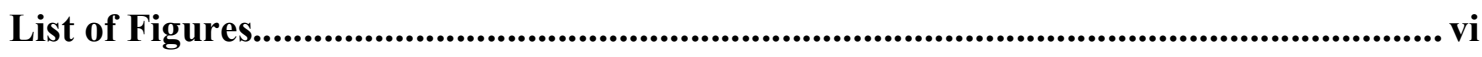

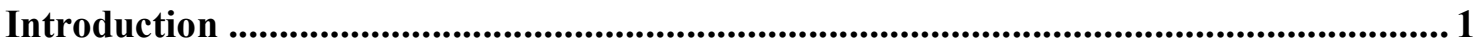

1. Framing the Death of the Prisoner ........................................................................9

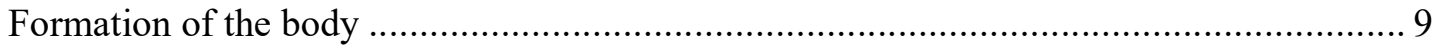

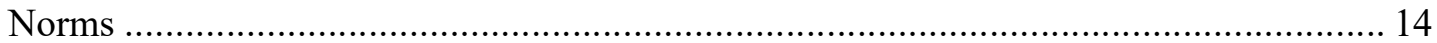

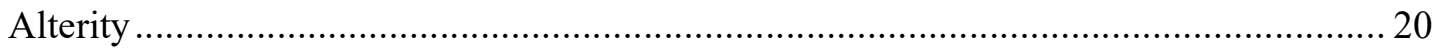

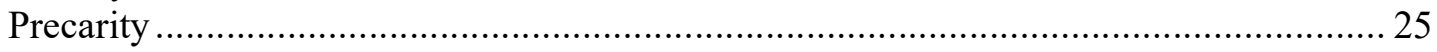

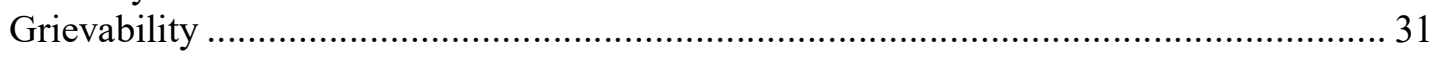

2. Conflict and Methods ..................................................................................... 35

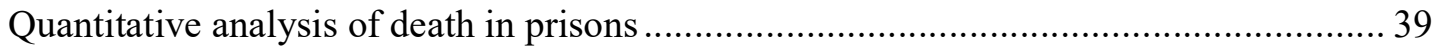

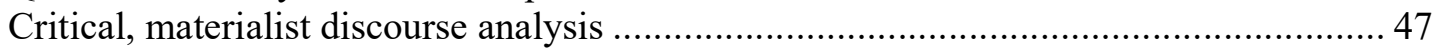

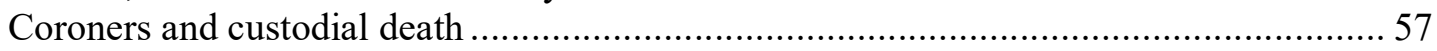

3. Counting the Death of the Prisoner ....................................................................6 61

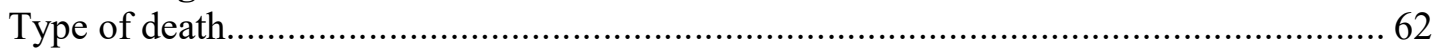

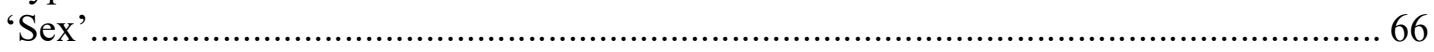

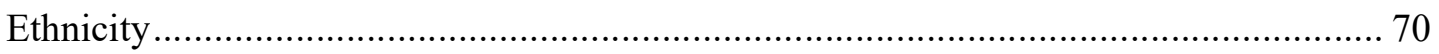

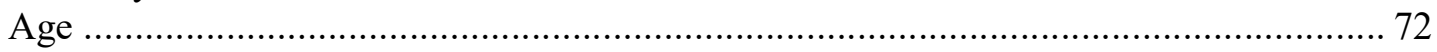

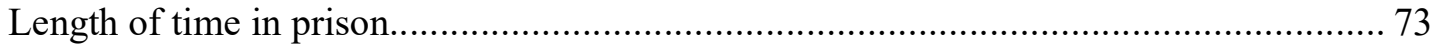

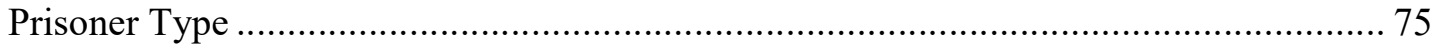

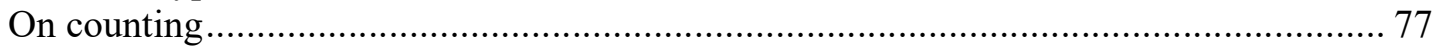

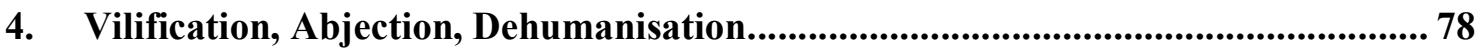

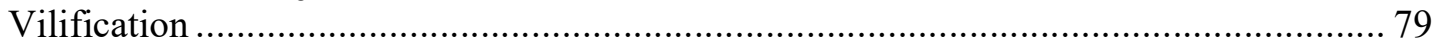

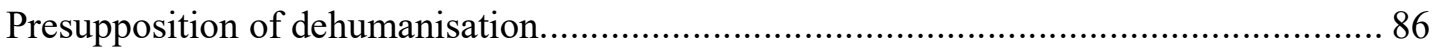

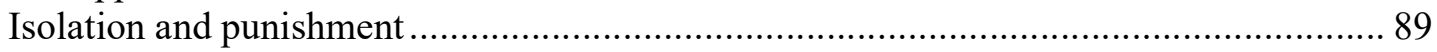

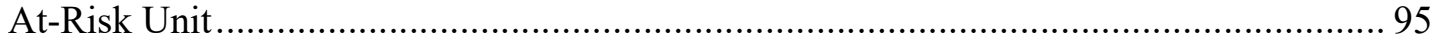

5. Vulnerability and the Distribution of Precarity ................................................... 105

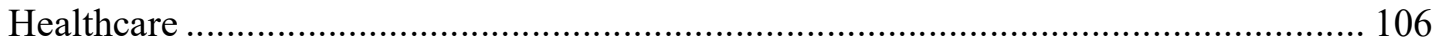

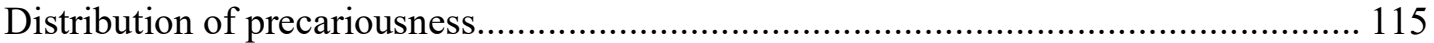

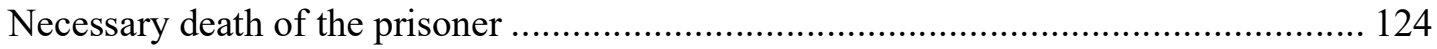

6. Grieving the Death of the Prisoner .......................................................................... 128

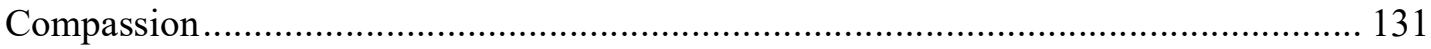

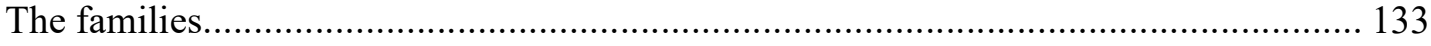

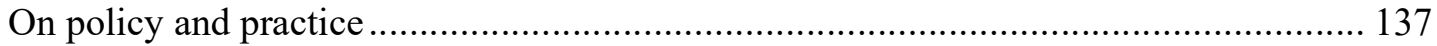

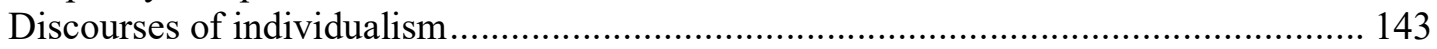

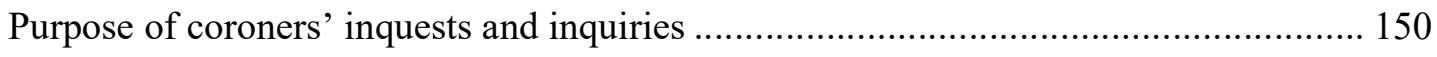

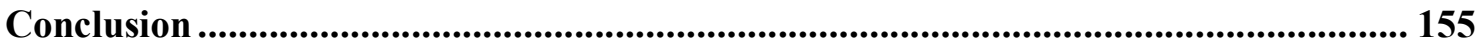

Appendix 1: List of Coroners' Findings .................................................................. 159

Reference List........................................................................................................................ 165 


\section{List of Tables}

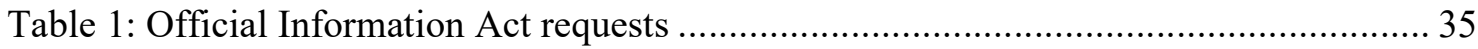

Table 2: Methods of quantitative analysis of coroners' findings (analysed) ........................ 42

Table 3: Methods of quantitative analysis of coroners' findings (not analysed).................. 43

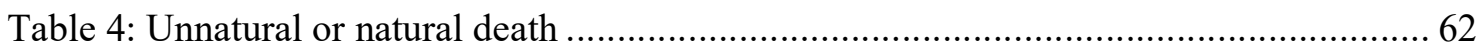

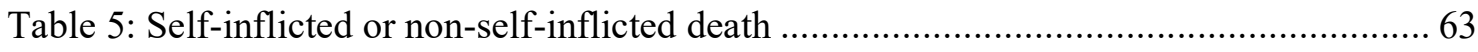

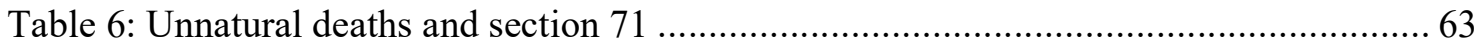

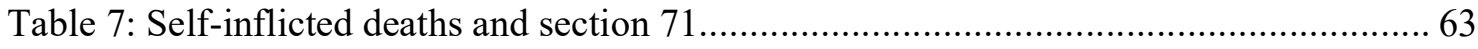

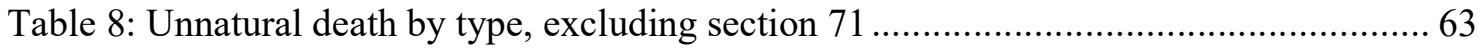

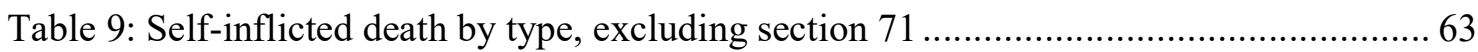

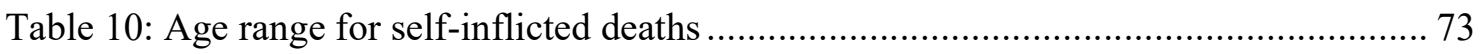

Table 11: Number of days in prison prior to death (all) ............................................ 74

Table 12: Number of days in prison prior to death (natural death) ................................. 74

Table 13: Number of days in prison prior to death (self-inflicted death) ........................... 74

Table 14: Occupation of deceased according to coroners' certificate of findings ................. 87

Table 15: Mean word count of coroners' findings into deaths in prison .......................... 135

Table 16: Mean word counts for findings based on family counsel and Howard League

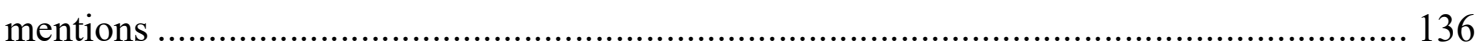




\section{List of Figures}

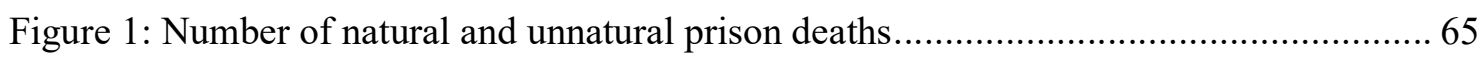

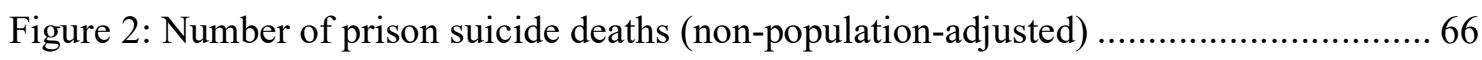

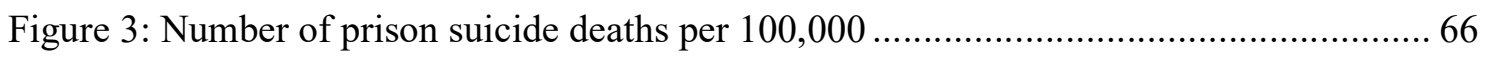

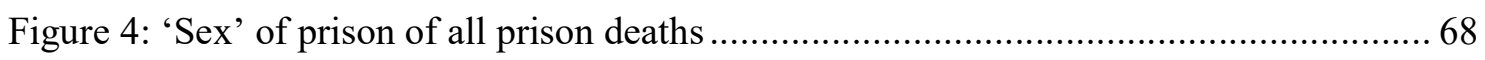

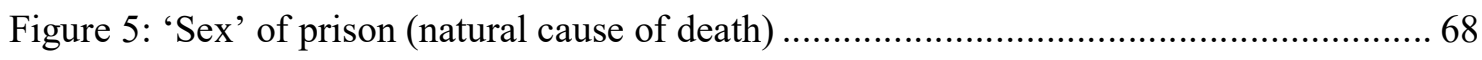

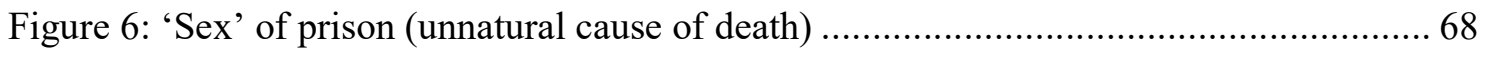

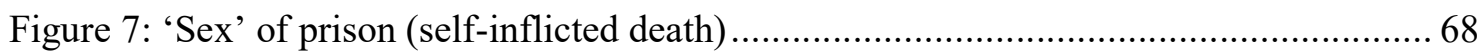

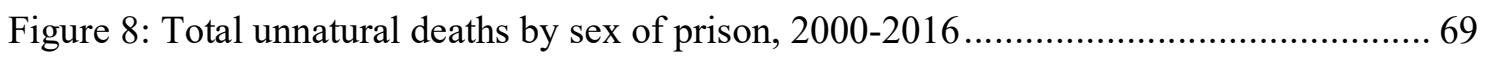

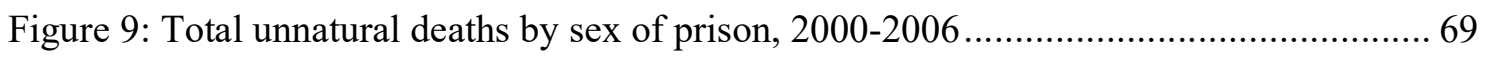

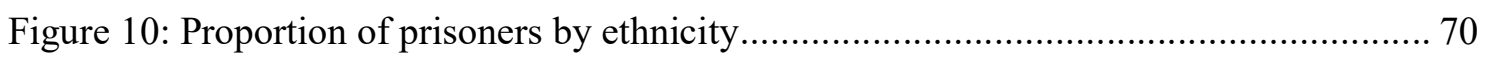

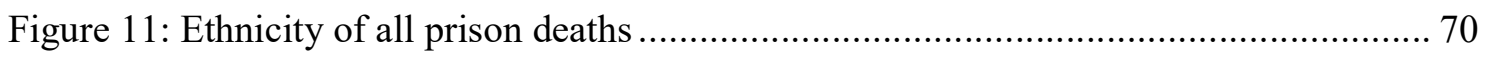

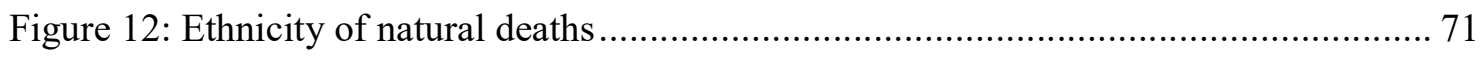

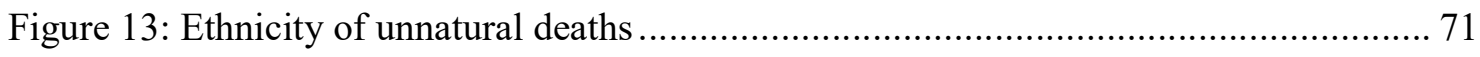

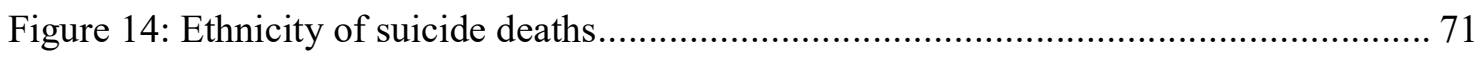

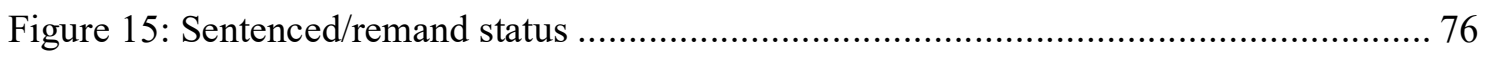

Figure 16: Sentenced/remand status of all deaths in prison ...................................... 76

Figure 17: Sentenced/remand status of death in prison (natural) ................................... 76

Figure 18: Sentenced/remand status of death in prison (self-inflicted) ........................... 76

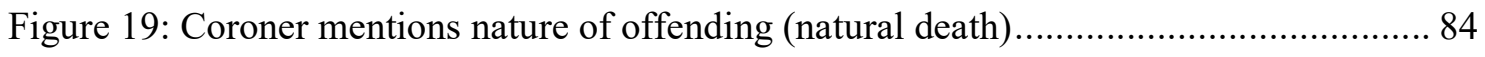

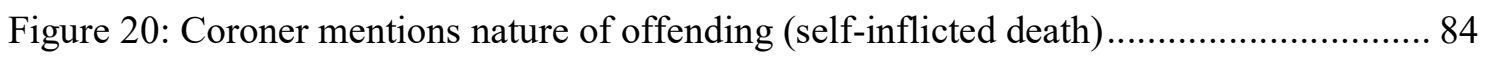




\section{Introduction}

The death of the prisoner occurs in a specific context. That context, in part, determines whether the life that was lost is a life worth grieving. The context exceeds the site of the prison. The prison itself is not an island, completely isolated and bearing no relation to the world around it. It exists as a result of historical processes and in a particular political economy. Prisons in Aotearoa, and the death of the prisoner, can only be understood in relation to the context of ongoing settler-colonisation and a capitalist mode of production.

The colonisation of Aotearoa, while the culmination of multiple complex and contradictory forces, in part occurred as a result of the need to accommodate a restless surplus labour supply in Britain and the continual drive for the expansion of capital (Steven 1989; Poata-Smith 2001). Evan Te Ahu Poata-Smith (2001) describes the economic formation of Aotearoa prior to colonisation as 'pre-capitalist'. Whereas a capitalist mode of production is defined by the ownership of the means of production being separated from the producers of commodities, there was communal ownership of the means of production (land) in pre-colonial Aotearoa (Poata-Smith 2001). Thus, 'Settler colonialism brought the Māori pre-capitalist mode of production into conflict with capitalist relations of production over access to land as a means of production' (Poata-Smith 2001, 68).

This conflict, while certainly bloody and hard-fought, resulted in the transformation of the mode of production into a capitalist mode of production. As Marx outlines, 'capitalist production presupposes the availability of considerable masses of capital and labour-power in the hands of commodity producers' (1976a, 873). For capitalist production to occur, first there 
must be an initial accumulation of capital, as well as the creation of a mass of people who need to sell their labour-power in exchange for payment. The production of the necessary preconditions for capitalism

is a process which operates two transformations, whereby the social means of subsistence and production are turned into capital, and the immediate producers are turned into wage-labourers. So-called primitive accumulation, therefore is nothing else than the historical process of divorcing the producer from the means of production. (Marx 1976a, 874-75)

In other words, capitalism requires the transformation of land and means of production owned in common into capital, a commodity privately owned. It also requires the separation of the producers, the labourers, from their ability to subsist on commonly owned land, requiring them to sell their labour-power to the owners of the means of production.

In Aotearoa, the history of 'primitive accumulation' is, like its European precursor, 'written in the annals of mankind [sic] in letters of blood and fire' (Marx 1976a, 875). The accumulation of land through the dispossession of Māori has taken multiple forms over nearly 200 years. This has included the large-scale 'sale' of land to the Crown, the claiming of land through military conquest, the confiscation of land through Acts of parliament, ${ }^{1}$ the requisition of land for public works, and the individualisation of title through the Native Land Courts (Steven 1989; Poata-Smith 1997, 2001; Walker 2004; Kawharu 2005; Mikaere 2011; Belich 2015). These processes, some of which continue today, have led to the widespread alienation of Māori

\footnotetext{
${ }^{1}$ Including the Suppression of Rebellion Act 1863, the New Zealand Settlement Act 1863, the Native Reserves Act 1864, and more recently the Foreshore and Seabed Act 2004.
} 
from the land. 'By the late 1930s, Māori retained less than one-sixth of the land. The fact that most of the remaining land was unsuitable for development, mean that iwi no longer possessed the acreage to feed themselves' (Poata-Smith 2001, 82).

The inability of most Māori to subsist on commonly-owned land meant they were largely forced to sell their labour-power commodity. During the 'long boom' following the Second World War, the alienation of Māori from the land led to their rapid urbanisation and proletarianisation. In this time, Māori largely worked in secondary and tertiary industries. The collapse and neoliberal restructuring of the New Zealand economy from the 1970s disproportionately affected the Māori working class, who have since experienced high levels of entrenched unemployment and poverty (Poata-Smith 1997, 2001, 2008, 2013). 'The brutal destruction of the traditional Maori economy, and the creation of a property-less class of Maori wage labourers with no direct access to the means of making a livelihood, are the key factors in placing the majority of Maori whanau in the working class, therefore affecting their levels of income, occupational distribution, educational attainment, health, unemployment, and housing' (Poata-Smith 1997, 178).

This brief contextualisation of settler-colonial capitalism in Aotearoa is crucial for understanding deaths in prisons for two reasons. First, the people who are most disenfranchised by the mode of production are those most likely to find themselves in prison. Incarcerated people in New Zealand are disproportionately likely to have lived in poverty prior to their imprisonment (National Health Committee 2010; Johnston 2016). According to an Official Information Act response to my request, in 2016 " 87 percent of prisoners did not pay any form of income tax in the month before entering prison. This indicates that 87 percent were 
unemployed, working for income but not paying tax, receiving a benefit, or being financially supported by another person" (Arbuckle 2017b, 2). In other words, up to $87 \%$ of prisoners were either unemployed or receiving such a low level of pay that they were not paying any income tax before their imprisonment.

As Māori are disproportionately likely to be living in poverty (Poata-Smith 2013; Simpson et al. 2016), they are similarly disproportionately represented in prisons. As of December 2016, Māori make up approximately $15.4 \%$ of the general New Zealand population (MacPherson 2017) and approximately $50.8 \%$ of the prison population (Department of Corrections 2017a). ${ }^{2}$ The overrepresentation of Māori in New Zealand prisons thus is a form of structural racism.

Second, the prison did not exist prior to colonisation (Lamusse, Morgan, and Rākete 2016; Kopeke-Te Aho et al. 2017; Rākete et al. 2017). Prior to colonisation, various whānau, hapū, and iwi adopted tikanga as a legal and values system guiding normative behaviour (Erueti 2004; Walker 2004; Mikaere 2005, 2011). 'Far from acknowledging tikanga as the first law of Aotearoa, the Crown proceeded on the racist assumption that Māori had no "real" law before the British arrived here to provide it' (Mikaere 2005, 334). The colonisers, bringing with them a political economic system incompatible with the colonised's, needed to impose a legal system that protected private property and the interests of the ruling classes of colonisers. Thus, when the British imposed their system of laws on various whānau, hapū, and iwi, the colonisers necessarily granted supremacy to these laws over the multiple different tikanga.

\footnotetext{
${ }^{2}$ At the time of publication, the December 2016 data is the most recently published data from Statistics New Zealand and the Department of Corrections, where the population snapshot dates overlap.
} 
This system of laws, of course, includes a criminal law which establishes codes of unacceptable behaviour. When a person is determined by the state to have broken this code, they are potentially liable for a penalty, including imprisonment. Sherene Razack $(2011,2015)$ argues that, in settler colonies, the purpose of the criminal law is to ensure the continued disappearance of indigenous people. 'Indigenous people stand in the way of settler colonialism, contesting settler entitlement to the land and throwing into question settler legitimacy as the original and rightful owners' (Razack 2015, 7). Rākete contends that the prison system has been used by colonisers to crush revolutionary decolonial movements in Aotearoa. 'The point is to destroy our ability to organise politically, to tear apart our communities so that they cannot resist the imposition of colonialism' (Rākete et al. 2017, 145).

Of course, imprisonment and prison deaths are not singularly Māori issues. Tracey McIntosh and Stan Coster note that if prison were 'simply a Māori issue, then we would expect to see Māori prisoners coming from all socio-economic categories and reflecting the broader Māori population. Yet the Māori prison population overwhelmingly comes from communities that live under conditions of scarcity and deprivation' $(2017,73)$. In this way, imprisonment does not affect all Māori in the same way, as it does not affect all tauiwi in the same way. It is not only the most impoverished Māori, but also others abjected from settler-colonial capitalism who find themselves in prison. However, this relationship between settler-colonial capitalism, impoverishment, and imprisonment is not the result of an innocent set of circumstances. 
Angela Davis argues that 'The process through which imprisonment developed into the primary mode of state inflicted punishment was very much related to the rise of capitalism and to the appearance of a new set of ideological conditions' $(2003,43)$. The ideological purpose of incarceration under capitalism is to imprison the poor in order to reproduce the social system. Jeffrey Reiman (2004) argues that the prison is, from the ruling class' perspective, a successful failure. Although it fails to meaningfully reduce social harm and crime, it succeeds 'by legitimating the present social order with its disparities of wealth and privilege and by diverting public discontent and opposition away from the rich and powerful and to the poor and powerless' (Reiman 2004, 5). The ideological effect of imprisonment, the reassurance that the state will protect the public from the threatening poor, justifies its repressive operation. In this way, capital can repress the threat to it from a mass of organised poor people (Parenti 2002), as well as ideologically reproduce the necessity of ruling class hegemony (Reiman 2004).

Therefore, as Kopeke Te-Aho et al. contend, 'Colonialism, capitalism, and mass incarceration are all part of the same tukutuku [grid, lattice-work] of oppression' (2017,31). As I demonstrate throughout this thesis, deaths in New Zealand prisons expose the excesses of this interwoven pattern of imprisonment and settler-colonial capitalism. The state's investigations and reports into these deaths, although undeniably limited, detail some of the dehumanising practices inflicted on bodies cast out into prisons. After each death in official custody, coroners are required to open an inquest or inquiry into the circumstances of the death. ${ }^{3}$ Following the inquest or inquiry, coroners produce a 'finding', in which they account for the death of the prisoner. The Coronial Office, on my request, provided me with every completed finding into a prison death in New Zealand, as far back as its records permitted. These findings provide rich

\footnotetext{
${ }^{3}$ Under section 60 of the Coroners Act 2006.
} 
insight into the experiences of the deceased in the lead up to their deaths, as well as how the state attempts to make sense of the death of people in its custody.

While this project is certainly underpinned by a Marxist analysis of settler-colonial capitalism and imprisonment in Aotearoa, the bulk of its theoretical framework is based on the work of Judith Butler. Although Butler is most often cited for her interventions into feminist and queer theory, my engagement with Butler's work draws on her analysis of language, norms, sociality, vulnerability, precarity and grievability across her oeuvre. I use Butler's theoretical framework here to aid my understanding of prison deaths. Her analysis facilitates a critique of the normative conditions of settler-colonial capitalism, demonstrating how norms that dehumanise the prisoner both exceed and encapsulate the prison.

It is, however, Butler's conceptualisation of grieving and grievability that can provide the richest insight for sociologically and politically understanding the death of the prisoner. Not only do these concepts help to explain the state's responses to the deaths, and the conditions of confinement preceding the deaths, but they crucially also provide the space for intervention. In this way, my purpose is not to merely reproduce the facts about deaths in prison, something the state itself does in the findings and in its own reports (Le Quesne 1995; Gardiner et al. 1996). The purpose is, instead, to expose the contradictions within the state's account of the deaths and to demonstrate the possibilities for transforming the life-destroying social conditions underpinning the deaths. 
I break the thesis down into six major chapters. Chapter 1, 'Framing the death of the prisoner' outlines the conceptual framework I construct alongside Butler. This is not and cannot be an exhaustive examination of her work. Instead, it demonstrates the logical and philosophical basis of my analysis. Chapter 2, 'Conflict and methods' details the specific methods and methodologies I use. It also provides some context about coroners' inquests and their inherent conflicts and contradictions. 'Counting the death of the prisoner', chapter 3, incorporates much of my findings from the quantitative analysis of the coroners' findings. It is a descriptive account of the population affected by prison deaths.

'Vilification, abjection, dehumanisation' demonstrates how coroners' findings presuppose the necessary vilification and abjection of the 'criminal' deceased. This presupposition enables the coroners' acceptance of the regularised practices of dehumanisation experienced by the deceased prior to their death. Chapter 5, 'Vulnerability and the distribution of precarity' starts with the presumption that all bodies, because of their existence in a social world, are vulnerable to the conditions of that world. I argue, however, that imprisonment exploits this generalised vulnerability, placing prisoners in positions of heightened precariousness. Finally, in chapter 6 , 'Grieving the death of the prisoner', I examine the state's attempt to grieve the loss of the prisoner and its struggle to recognise the life of the prisoner. 


\section{Framing the Death of the Prisoner}

\section{Formation of the body}

To grapple with the meaning of the death of the prisoner, I start with the matter with which we matter, the human body. Butler (2011) takes issue with both those forms of essentialism that posit a materiality completely distinct from language, which fundamentally limit social formations to biological or symbolic givens, as well as those forms of constructivism that propose that there is nothing outside of social construction.

Instead, Butler proposes a way of thinking of materiality and language as 'never fully identical nor fully different' (Butler 2011,38). Taking the body that types this text as an example, the physical body is only knowable through a language that exceeds this body. This body can only come to know its fingers, aching neck and the grimy plastic of the keyboard because of a language that did not begin with it. Being able to describe these small appendages at the extremities of my body as fingers, as something different from toes, can only occur because I have access to a language that can refer to them as such. This is not, however, to say that these fingers would not exist if I had no way to describe them. Instead, this body can only come to know its materiality through language. I can only know these fingers as fingers because the linguistic category 'finger' exists.

These typing fingers further attest to the materiality of language itself. This page that you read requires the movement of a body in a certain way, including the tapping of fingers in the correct order, the movement of the eyes that read. In this sense, this language is a material bodily language, being both transmitted and received via bodies. 
How, then, do I make sense of the materiality of this body which is only understandable through language? I am made up of matter that includes lungs that enable me to breathe, a heart that pumps blood through my body, as well as a multitude of biological processes that make this act of typing possible. I must consume and excrete matter for these biological processes to continue. Regardless of how these processes are signified, certain material practices must occur for this body to survive. This cannot be denied. 'But the undeniability of these "materialities" in no way implies what it means to affirm them, indeed, what interpretive matrices condition, enable and limit that necessary affirmation' (Butler 2011, 36). Although there exist these material givens, my ability to access them and to make sense of them requires language.

In this way, materiality cannot be accurately posited as prior to language. The body is not a canvas on which language paints. 'The body posited as prior to the sign, is always posited or signified as prior' (Butler 2011, 6, emphasis original). The act of positing is itself a linguistic act that signifies that body prior to signification. This signification of materiality prior to the sign is 'constitutive' of that body, 'inasmuch as this signifying act delimits and contours the body that it then claims to find prior to any and all signification' (Butler 2011, 6). However, to argue that discourse is 'constitutive' or 'formative' of the body is not to say that language is the singular origin of the body. Rather the 'language through which the body emerges helps to form and establish that body in its knowability, but the language that forms the body does not fully or exclusively form it' (Butler 2015b, 21). 
Although we can only know the body through language, we can also only misapprehend or partially apprehend the body. While the 'body is given through language, it is never fully given in that way, and to say that it is given partially can be understood only if we also acknowledge that it is given, when it is given, in parts - it is, as it were, given and withheld at the same time, and language might be said to perform both of these operations' (Butler 2015b, 20). It necessarily exceeds capture by language, where the conventions and categories of language do not facilitate the recognition of some bodies in some spaces.

In this sense, there is an outside to linguistic construction, a potentially unknowable, incomprehensible excess. However, that is not an 'absolute' outside that would suggest an ontological separation between language and materiality (Butler 2011, xvii). This outside is a constitutive outside that exists at and enables the establishment of the borders of the knowable. The constitutive outside haunts the language from which it is excluded, threatening to upend its linguistic coherency. A key distinction between Butler and those constructivists who hold that 'everything is discursively constructed' is Butler's claim that in the constitution of discourse, there is 'exclusion, erasure, violent foreclosure, abjection and its disruptive return within the very terms of discursive legitimacy' (Butler 2011, xvii). Not all bodies matter via discourse, in both the sense of being materialised and being important, precisely because of the exclusion of some bodies, such as those which are imprisoned, from the discursive regime.

How does this thing that is tentatively called a body come into being as a linguistic being? As Butler (1997b, 2006a, 2011) is at pains to note, grammar here becomes difficult. If we reject 
the priority of materiality over language because the positing of that priority requires language, then it is challenging to describe the process of this body becoming recognisable as a body. As a partial response to this challenge, Butler (1997a, 1997b, 2011) offers a reading of Althusser's (2001) 'Ideology and Ideological State Apparatuses'. For Althusser (2001), the subjection of the body occurs through ideological interpellation. Although this topic will be considered in greater detail in the next section of this chapter, it is important to note for now that the subject does not connote a coherency 'identified strictly with the individual' but 'ought to be designated as a linguistic category, a place-holder, a structure in formation' (Butler 1997b, 10).

In the scene of interpellation that Althusser constructs, a body is hailed by a police officer who calls 'Hey, you there!' $(2001,174)$. This hailing of the thing-that-is-not-yet-a-subject, which Althusser clumsily refers to as an 'individual,' in combination with the turning around of the thing, is what interpellates it as a subject. It is only by being conferred the status of a 'you' that an 'I' can emerge. As Butler argues, 'the "I" only comes into being through being called, named, interpellated, to use the Althusserian term, and this discursive constitution takes place prior to the "I"; it is the transitive invocation of the "I"" $(2011,171)$.

In this way, language precedes our social formation as subjects, making that very process possible. Returning again to the impossible situation in which there exists a body which has 'not yet been given social definition' (Butler 1997a, 5), which has not undergone subjection, this body, while physically present, is not knowable as a body until it is interpellated. In order to access this body, it must undergo an 'an interpellation that does not "discover" this body, but constitutes it fundamentally' (Butler 1997a, 5). The body cannot be 'discovered', precisely because any such 'discovery' would mean that the body existed in some other realm and was 
merely found as it existed by language. Instead, language founds the body, constituting its borders and limiting what can be considered bodily. The language here of a pre-interpellated body is therefore not only difficult but impossible.

As Althusser stresses, interpellation as ideological subjects in no way requires recognition of that ideology or interpellation. Even from the moment the child is born, it is 'always-already a subject' (Althusser 2001, 176). By this stage the new-born, without linguistic comprehension, may be given a name and a gender, and will already be immersed in a normative environment that places ideological expectations and limitations on the child. As Butler argues, 'One need not know about or register a way of being constituted for that constitution to work in an efficacious way. For the measure of that constitution is not to be found in a reflexive appropriation of that constitution, but, rather, in a chain of signification that exceeds the circuit of self-knowledge' (1997a, 31).

This 'chain of signification' refers to a language that one is born into that is not of one's choosing. To be interpellated as a subject assigned to the category of 'girl', for example, a series of ideological practices are required to establish the category of the 'girl' and the subject's eligibility for it. These ideological practices, however, are also material, taking form in practices such as the material way caregivers clothe a new-born to signify her ideological interpellation as a girl. As the production of ideologies and subjects requires material practice, Althusser (2001) rejects the distinction between materiality and ideology, claiming that ideology exists to the extent that it is inscribed in ritualised material practice. 
Butler stresses that the interpellation of the subject is cannot be limited to the voice of authority ('Hey you there!'), which is able to 'bring about what it names' (Butler 1997a, 32). There are non-verbal and diffuse workings of power that constitute the subject without its knowledge. Even with the 'medical interpellation' of the doctor who exclaims 'it's a girl!', the "“girling”" of the girl does not end there' (Butler 2011, xvii). Instead, the girl continues to be girled on written documents such as birth certificates, bureaucratic forms, as well as all those practices that may or may not continue throughout the subject's life to indicate their girlness. Similarly, the judge announcing a sentence of imprisonment does not, once-and-for-all establish the prisoner-subject. The interpellation of the person-as-prisoner continues through material practices of imprisonment.

The crucial point, therefore, is that subjects are not interpellated once and for all. Butler's reading of Althusser concludes that 'the constitution of the subject is material to the extent that this constitution takes place through rituals, and these rituals materialize "the ideas of the subject"' (Butler 1997b, 121-22, citing Althusser 1969, 169, emphasis original). These rituals require consistent reaffirmation, so as not to lose faith in the ideological formation that is ritualised. In this way, ideology and the production of subjects of ideology requires its own reproduction through material practices.

\section{Norms}

For Butler, a norm 'is not the same as a rule, and it is not the same as a law. A norm operates within social practices as the implicit standard of normalization' $(2004,41)$. Normalisation is the process by which 'ideas and ideals hold sway over embodied life' and 'provide coercive 
criteria for normal' bodies (206). The norm, operating as an ideal, must be embodied in regular social practices to remain normative. Norms are material in that they exist in everyday practices, even where they are difficult to discern as a norm.

There is no 'one' who stands prior to norms as there 'is no subject prior to its constructions' (Butler 2011, 84). Instead, norms both bring the 'one' into being through interpellation and sustain that 'one' as a subject intelligible to that norm. This subject remains intelligible by engaging in material social practices that approach the normative standard. The girl who was medically interpellated as a girl has her girling sustained through the concerted action of those on whom she depends when she is an infant, as well as her own actions in concert with others that support (or reject) her subjectivation as a girl. For this girling to continue, she must continue to approximate the gendered norms, as they change throughout her life, and others must continue to girl her. These gendered norms are reproduced by the actions of subjects, who in their material social practices reinstate the ideals of girlness.

This does not mean that the subject is somehow able to decide at will how it will performatively construct itself. For a normative gesture to be understandable as such, it must recall previous gestures and be understandable in relation to them. Butler (1997a, 51, 2011, xxi) often quotes the following passage from Derrida's essay 'Signature Event Context' to explain this:

Could a performative utterance succeed if its formulation did not repeat a "coded" or iterable utterance, or in other words, if the formula I pronounce in order to open a meeting, launch a ship or a marriage were not identifiable as conforming with an iterable model, if it were not then 
identifiable in some way as a "citation"? ... In such a typology, the category of intention will not disappear; it will have its place, but from that place it will no longer be able to govern the entire scene and system of utterance (Derrida 1988, 18, emphasis original)

In this way, in the performative medical interpellation of the girl by the doctor ('it's a girl!'), the doctor is restricted in their capacity to make such a declaration. It is only because of a history of gender norms in which 'girl' has a specific meaning that the doctor can cite that norm to make the declaration. Similarly, the girl is limited in terms of the performative acts she can enact to be recognisable as a girl according to gender norms.

More broadly, the entire social system requires constant reproduction to continue to exist. The capitalist mode of production itself requires not only the production of commodities for the continual expansion of capital, but also the reproduction of the conditions of production (Marx 1976a; Althusser 2001). In the same way, the normative environment which ideologically sustains submission to capitalism must itself be reproduced. The norm must be continually reproduced as normative to remain a norm. In this sense, while the subject is dependent on the norm to produce and reproduce the subject, the norm requires the subject's repeated social practice to be reidealised.

Gender, and norms generally, are established through 'the repeated stylization of the body, a set of repeated acts within a highly rigid regulatory frame that congeal over time to produce the appearance of substance, of a natural sort of being' (Butler 2006a, 45). ${ }^{4}$ It is in this way

\footnotetext{
4 The language of 'congealing' and 'appearance' echoes Marx's discussion of commodity fetishism, as Butler $(2006 \mathrm{a}, 45)$ notes.
} 
that 'contingent acts' produce 'the appearance of a naturalistic necessity' (Butler 2006a, 45). Butler provides the example of sex as something that is materialised and naturalised through normativity. It is through the socially accepted and ritualistic designation of the category 'girl' to the new-born, among a multitude of other processes, that the category of the 'girl' appears to be a natural part of human life, despite the anthropological demonstration that such a category is not culturally universal.

This process of normalisation can be applied to institutions such as the prison, which appear to be a natural part of contemporary society. Angela Davis argues that the "prison is considered so "natural" that it is extremely hard to imagine life without it' $(2003,10)$. The ideological production of the prison makes it hard to envisage alternatives because the very way that the state deals with harm is infused in a carceral logic that presupposes punishment as a solution. However, in the same way that an interrogation of the performativity of gender reveals the contingency of sex, the prison's contingency or unnaturalness is similarly exposable. The prison is not a naturalistic necessity but is also a site which requires constant reproduction.

Although norms create the appearance of naturality, they are not singular and coherent structures which fully determine those interpellated by them and who enact them. Butler stresses that norms can act on us, and create expectations for us, in 'contradictory ways' (2015b, 5). It is also not possible to demonstrate a causal series between a single norm and the production of a subject. Norms do not always and only produce that which is intended. 'Even as norms seem to determine which genders can appear and which cannot, they also fail to control the sphere of appearance, operating more like absent or fallible police than effective totalitarian powers' (Butler 2015a, 39). 
Butler notes that the bodily repetition of norms is enacted because of compulsion. 'The subject is compelled to repeat the norms by which it is produced, but that repetition establishes a domain of risk, for if one fails to reinstate the norm "in the right way," one becomes subject to further sanction, one feels the prevailing conditions of existence threatened' (Butler 1997b, 2829). In other words, if we fail to re-enact those norms that form us and fail to approximate the normative ideal, our very subjecthood is threatened, sometimes through imprisonment.

In this way, the norm depends on the possibility of exclusion to compel reiteration. For a norm to be sustained, it requires a constitutive outside. The constitutive outside is that which is excluded from the normative environment and which is unrecognisable according to it. For Butler, subjection

requires the simultaneous production of a domain of abject beings, those who are not yet "subjects," but who form the constitutive outside to the domain of the subject. The abject designates here precisely those "unlivable" and "uninhabitable" zones of social life which are nevertheless densely populated by those who do not enjoy the status of the subject, but whose living under the sign of the "unlivable" is required to circumscribe the domain of the subject' $(2011$, xiii)

The abject is thus constitutive of the subject. It is only through the production of zones of inhumanity, that the borders of human subjection are established. It is, in this way, incorporated into the human subject, as the subject is defined against what it is not, and threatened by its own potential repudiation. 
For Butler, the 'paradox of subjectivation (assujetissement) is precisely that the subject who would resist such norms is itself enabled, if not produced, by such norms' (2011, xxiii). This echoes Marx, in that the necessary conditions for the destruction and transformation of a social system arise from the contradictions of that system. ${ }^{5}$ Capital requires the working class to continually reproduce capital by going to work and producing commodities. If it were not for the creation of the working class itself, capital would not have the labour-power it needs to produce value. However, at the same time, the political body that can enable the movement beyond capitalism is the working class.

Just as capital provides the working class with the tools to both reproduce and destroy capitalism, Butler argues that there 'is only a taking up of the tools where they lie, where the very "taking up" is enabled by the tool lying there' (2006a, 199). Butler uses a prisoner going on hunger strike as an example of highly conditioned political possibility. 'The prisoner who continues to eat keeps the machinery of the prison running, so the starving prisoner exposes the inhumanity of that machinery, of those prison conditions, formulating a "no" through bodily actions that may or may not take the form of speech' (Butler and Athanasiou 2013, 145). In other words, it is only by being interpellated as a prisoner that the prisoner can use that specific interpellation to threaten to expose the inhumanity of their imprisonment, as well as the contingency of the prison.

\footnotetext{
${ }^{5}$ As Marx famously argues, 'Men [sic] make their own history, but they do not make it just as they please; they do not make it under circumstances chosen by themselves, but under circumstances directly encountered, given and transmitted from the past' $(1963,15)$. The link between Butler and Marx's conditional politics was outlined brilliantly by Anna-Maria Murtola (2016) at the Social Movements, Resistance and Social Change III Conference in September 2016.
} 
Butler, although not explicit, is therefore opposed to those forms of utopianism that deny the current conditions of exploitation. Political change can only arise out of the conditions as they stand. Importantly, the subject, which can include a collective political subject (Butler 2015a), can exceed the limitations and exploitation through which it is produced. However, 'Exceeding is not escaping, and the subject exceeds precisely that to which it is bound' (Butler 1997b, 17). In other words, for power that immiserates to be undone, that power must first immiserate.

\begin{abstract}
Alterity ${ }^{6}$
As I have reiterated throughout this chapter, the subject requires a sociality that exceeds any given subject. Alterity as a concept, while certainly present in Butler's earlier work, ${ }^{7}$ fundamentally enriches her work after her engagement with Emmanuel Levinas' thought in the early 2000s. She argues that the "norms by which I recognize another or, indeed, myself are not mine alone. They function to the extent that they are social, exceeding every dyadic exchange that they condition' (Butler 2005, 24). In other words, my ability to recognise myself and others as human depends on a normative regime which is not limited to myself and one other. Instead, the relationship between me and you is dependent on alterity or absolute otherness.
\end{abstract}

\footnotetext{
${ }^{6}$ I owe much of my, however limited, understanding of alterity to Campbell Jones. His course on the Other and his forthcoming book, The Work of Others (Jones Forthcoming), profoundly affected my understanding of Butler and her interlocutors.

${ }^{7}$ Butler's consistent engagement with Hegel's work means that the Other is ever-present in her work and is especially important to her first work, Subjects of Desire (2012b).
} 
When I am born into the world, I am born into a whole series of social relations about which I can never be fully aware. 'The infant enters the world given over from the start to a language and to a series of signs, broadly construed, that begin to structure an already operative mode of receptivity and demand' (Butler 2005, 77). As a result, my body is exposed from the very beginning to a political-economic system and normative regime that can either sustain or threaten my being. To 'be a body is to be exposed to social crafting and form, and that is what makes the ontology of the body a social ontology' (Butler 2010,3). The very being of my body thus depends on a sociality to sustain its being.

Bodily exposure to sociality is a material social relation. My body only exists to the extent that it is supported, to the extent that I continue to be physically nourished and sustained biologically. This sustenance occurs because of my relation to those material things that nourish me. In this way, 'the body is less an entity than a living set of relations; the body cannot be fully dissociated from the infrastructural and environmental conditions of its living and acting' (Butler 2015a, 65). In this sense, the body is inseparable from that which supports and sustains it, meaning that the body is made up by the material social relations that enable its continued existence.

My body is always-already given over to the social, never truly just my own body. 'The body has its invariably public dimension; constituted as a social phenomenon in the public sphere, my body is and is not mine. Given over from the start to the world of others, bearing their imprint, formed within the crucible of social life, the body is only later, and with some uncertainty, that to which I lay claim as my own' (Butler 2004, 21). In this paradoxical way, the sociality of my body, the impossibility of knowing or sustaining the body without a 'world 
of others', make my body not truly just mine. A necessary condition of my autonomy over my body, which can never be fully achieved, is the dispossession of my body to a sociality that shapes and conditions it. Butler argues therefore that we are 'social beings from the start' (2010, $23)^{8}$

There is a 'necessary dependency' of myself on the other that can never be foreclosed (Butler 2004, 24). Even now, well past infancy, I am still fundamentally dependent on others for my persistence. Butler argues 'that no one, however old, ever grows out of this particular condition, characterized as dependent and susceptible' (2015a, 131). I remain dependent on a multitude of others whom I can never fully recognise. My ability to persist is dependent on workers who ensure sewers continue to flow, on agricultural workers who make my food, as well as my family, friends and lovers who emotionally sustain me.

I also remain susceptible in that, by virtue of having a material human body, my life can be 'expunged quite suddenly from the outside and for reasons that are not always under one's control' (Butler 2010, 30). In this sense, vulnerability is not a feature that just some individuals' experience, being at a heightened risk of violence or death. Vulnerability is not "just a trait or an episodic disposition of a discrete body, but is, rather, a mode of relationality that time and again calls some aspect of that discreteness into question' (Butler 2015a, 130). It is a condition of existence that fundamentally undermines liberal notions of atomistic individualism. Vulnerability, as a relation, demonstrates that the body can never be that of a discrete individual,

\footnotetext{
${ }^{8}$ This, of course, draws on Marx's claim that the human 'is a social animal' (Marx 1976a, 444).
} 
as that 'individual's' vulnerability requires that body to be always given over to the other to be sustained.

One's fundamental vulnerability means that one depends on 'the conditions of one's own production' (Butler 2010, 170-71). In this way, when Butler claims that the body is vulnerable, she argues 'that the body is vulnerable to economics and to history' (Butler 2015a, 148). The specific historical conditions that sustain the body are constituted, in part, by the political economy in which the body finds itself. 'Conditions have to be sustained, which means that they exist not as static entities, but as reproducible social institutions and relations' (Butler 2010, 24).

In this way, we become subjects and remain vulnerable to the conditions at hand. This vulnerability enables our exploitation. 'The condition of the possibility of my exploitation presupposes that I am a being in need of support, dependent, given over to an infrastructural world in order to act, requiring an emotional infrastructure to survive' (Butler 2015b, 7). I am exploitable because I am dependent on a wage to reproduce myself. Because I require a wage to survive, my employer can exploit me by extracting surplus value from my labour-power. 'If a laborer depends on an employer by whom he or she [sic] is exploited, then that laborer's dependency appears to be equivalent to his or her capacity to be exploited' (Butler 2015a, 209).

This exploitability, stemming from my vulnerability, is exploited in the specific political economy and historical moment in which I live. The specificity of my exploitability arises from a historical process. At the advent of capitalism, the vulnerability of peasants was exploited to 
create a class of labourers that could be employed by capital. Through the process of primitive accumulation, where common land that peasants used to sustain themselves was forcibly and sometimes violently privatised, those who lost their ability to reproduce themselves through the land were forced to sell their labour-power to capitalists in order to survive (Marx 1976a).

As demonstrated in the introduction, an equivalent process occurred in the colonisation of Aotearoa, where the vast majority of Māori were made landless and divorced from their traditional means of production (Poata-Smith 1997, 2001). Consequently, the colonisers were able to exploit the vulnerability of landless Māori, necessitating proletarianisation. Because of these historical processes, capital can continue to exploit labour, as the bodily reproduction of the labourer depends on the wage provided by the employer.

In this way, although we are all vulnerable, the material environment in which we find ourselves will lead to the exploitation of some bodies' vulnerabilities to greater degrees than others'. It, nonetheless, remains that despite this differential exploitation, the fundamental condition of bodily life is our precariousness. For Butler, precariousness 'implies living socially, that is, the fact that one's life is always in some sense in the hands of the other' (2010, 14). Precariousness is a 'generalized condition' that exists across all lives (Butler 2010, 22). It means both exposure to and dependency on the other and the other's dependency and exposure to oneself. 'To say that life is precarious is to say that the possibility of being sustained relies fundamentally on social and political conditions' (Butler 2010,21). We are also precarious in that our dependence on those social and political conditions in no way guarantees our persistence. 


\section{Precarity}

Precarity, as distinct from precariousness, refers to 'that politically induced condition in which certain populations suffer from failing social and economic networks of support and become differentially exposed to injury, violence, and death' (Butler 2010, 25). Just as exploitation is possible due to our primary vulnerability, our need for support from social conditions that exceed us mean that lives 'are supported and maintained differently, and there are radically different ways in which human physical vulnerability is distributed across the globe' (Butler 2006b, 32).

Thus, the reason our precariousness and vulnerability matter is due to the material and differential consequences of it. While the capitalist may depend on the worker to produce value, and the worker may withdraw their support for the capitalist, the worker's dependence on the wage provided by the capitalist makes the worker a victim of exploitation and the capitalist able to accumulate capital. The 'politically induced' condition of precarity depends on a primary equality of precariousness, while producing an unequal distribution of injury and exploitation.

In this way, the bodily ontology I have been building here alongside Butler is one that is always historically and politically constituted. 'The "being" of the body to which this ontology refers is one that is always given over to others, to norms, to social and political organizations that have developed historically in order to maximize precariousness for some and minimize precariousness for others' (Butler 2010, 2-3). Consequently, this social ontology of the body 
demonstrates that in the current political economic situation, the 'general truth' of our social dependency 'is lived differentially, since exposure to injury at work, or faltering social services, clearly affects workers and the unemployed much more than others' (Butler 2015a, 21).

Butler thus provides a sociological account of how 'individual' suffering is not the result of 'individual choice' but because of the political allocation of differential precariousness:

In other words, no one person suffers a lack of shelter without there being a social failure to organize shelter in such a way that it is accessible to each and every person. And no one person suffers unemployment without there being a system or a political economy that fails to safeguard against that possibility (Butler 2015a, 21-22) ${ }^{9}$

This, along with the rejection of the liberal conception of the individual, reformulates responsibility as something that is also socially constituted, rather than something designated to a fictional individual.

For Butler, the concept of precarity holds promise for a politics of solidarity 'in ways that continue to exceed and traverse the categories of identity' (Butler 2010, 3). Butler, in this way, extends the argument that she makes throughout her career that identity is not a useful basis for politics, or even an effective way to account for those material conditions experienced by various identities. Instead of taking an identity category and making a metaphysical claim to oppression based on that identity, a politics of precarity takes the differential and material distribution of precariousness as the starting point, a distribution that transcends identity.

\footnotetext{
${ }^{9}$ This argument certainly echoes C. Wright Mills' (2000) The Sociological Imagination, see page 9.
} 
'Precarity cuts across identity categories as well as multicultural maps, thus forming the basis for an alliance focused on opposition to state violence and its capacity to produce, exploit, and distribute precarity for the purposes of profit and territorial defense' (Butler 2010, 32).

In an odd sense, it is almost as if Butler has discovered what has been haunting her work for decades: class. The differential distribution of wealth and poverty occurs because of a mode of production that, out of necessity, exploits the many for the benefit of the few. That differential distribution certainly cuts across identity categories, enabling some who hold a certain identity to economically exploit others, including those to hold the same identity. However, in the above quotation, Butler quite deliberately points to the state and 'state violence' as the cause of the differential distribution of precariousness. While it may make sense to see the state's role in this with regard to warmongering and Islamophobic security measures (see: Butler 2006b, 2010, 2012a), Butler's failure to ask why the state would engage in such behaviour demonstrates her persistent lack of a materialist political economic analysis.

Across her work, Butler describes the state in complex and contradictory ways. At some points she demonstrates, in a dialectical manner, that the 'state is not a simple unity and its parts and operations are not always coordinated with one another' and it does not operate 'with a single set of interests' (Butler 2004, 116). While at others she notes that the alliance necessary to undo the worst forms of precarity 'would need to stay focused on methods of state coercion' (Butler $2010,149)$. In the same breath she notes, however, that 'we cannot take account of power if we always place the state at the center of its operation. The state draws upon non-statist operations of power and cannot function without a reserve of power that it has not itself 
organized' (Butler 2010, 149). Nonetheless, 'the point is to establish a politics that opposes state coercion' (Butler 2010, 132).

And so, it appears that Butler's politics are in a bind. While it is undeniable that opposition to state coercion may provide a node of alliance for a divided left, I would argue that it misdiagnoses the issue. As Butler notes, the state is not ultimately a singular and unified thing. It can be a vehicle for cooperation that unleashes human potential while also an unquestionable tool for mass death and destruction. Further, while Butler is right to argue that the state is an important site for struggle over the differential distribution of precarity, politics cannot be reduced to the state, as power is irreducible to the state. In this way, we need to take account for the causes of state coercion and not simply attribute it to the state itself having an unexplained desire for destruction.

Why not then build a politics of precarity based not on our mutual opposition to state coercion but the coercive forces of capital that are exacted, in part, through the state? Would precarity then be another way of framing a return to a working class revolutionary agent that takes account for the racialised, gendered and other ways that norms are reproduced through class? While such a politics is certainly necessary, it is not what Butler is attempting to do here. Although my Marxist reading suggests a possible overlap between such a movement and Butler's analysis, Butler's precarity offers something in addition to just class.

If we accept that the norms that do harm to us are irreducible to economic oppression, even if economic oppression leads to some of the direst material consequences and those norms are 
often effected through economic means, then we must find some way to create a politics that exceeds class while never forgetting it. Butler's precarity attempts to do this, as it links the material consequences of the current mode of production to violence against those who are not comprehensible according to gender norms, as well as violence against women and racialised discrimination. All of these modes of oppression exploit our fundamental vulnerability and differentially distribute precarity according to normative standards that cannot always be accounted for through class.

This is where the strength of precarity as a sociological concept and political unifier emerges. Precarity demonstrates that our fundamental vulnerability enables our exposure to violence and exploitation, while also allowing for our cooperation and political transformation. In such a way, a true politics of precarity cannot only fight for the liberation of workers, but must also fight for a liberation from the other normative frameworks that oppress us, including and not limited to colonialism, gender, and race. However, where Butler reduces that unification to the opposition to state violence, and where she fails to account for how capital underpins much of this violence, her analysis falls woefully short.

Butler's analysis of the human and its grievability provides an enrichment to the politics of precarity. For Butler, one's grievability depends on whether the life one has lived is recognisable as a human life. While precarity and oppression lead to a differential distribution of suffering, to be completely unintelligible according to the norms that construct the human body 'is to find that you have not yet achieved access to the human, to find yourself speaking only and always as if you were human, but with the sense that you are not, to find that your 
language is hollow, that no recognition is forthcoming because the norms by which recognition takes place are not in your favor' (Butler 2004, 30).

This failure to gain recognition as a human is a material failure that leads to an 'unlivable life', a life that does not enjoy life-sustaining social conditions (Butler 2004, 2). As argued above, the construction of the dehumanised or abjected body is necessary for a norm to persist. Norms require a constitutive outside to police the borders of that norm. Consequently, where 'there is the human, there is the inhuman' (Butler 2010, 76). This creates a paradoxical situation in which there is 'a human who is no human' (Butler 2010, 76). While this life is dehumanised and may be apprehensible as human, it fails to be recognised as a human life worth preserving.

As a result, 'certain lives are not considered lives at all, they cannot be humanized; they fit no dominant frame for the human, and their dehumanization occurs first, at this level' (Butler 2004, 25). When violence is done to those bodies that are not recognisable as human, that violence is similarly unrecognisable as violence done to a person. Using the example of torture, Butler argues that 'when some group of people comes to represent a threat to the cultural conditions of humanization and of citizenship, the rationale for their torture and death is secured-since they can no longer be conceptualized as human or as citizens' $(2010,131)$. The material dehumanisation torture entails 'is not only presupposed by the torture, but reinstituted by it' (Butler 2010, 93). As I argue in the following chapters, the body of the prisoner is unrecognisable as human, and consequently has the dehumanisation of its body reinstated through its maltreatment. 


\section{Grievability}

The inability to be recognised as human is fundamentally linked to that body's grievability. For Butler, some 'lives are grievable, and others are not; the differential allocation of grievability that decides what kind of subject is and must be grieved, and which kind of subject must not, operates to produce and maintain certain exclusionary conceptions of who is normatively human: what counts as a livable life and a grievable death?' (2006b, xiv-xv). The process of grief, where we accept the loss of the other and the constitution of the other in us, is foreclosed for those bodies that are not grievable or are inhuman. The loss of these bodies cannot be registered as a loss according to the norms that establish the human, as such a registration would require the reformulation of the norm to incorporate the lost body within the regime of the human.

For Butler, 'grievability is a presupposition for the life that matters' $(2010,14)$. The mattering of the life occurs in both senses that Butler refers to: that the life is important and that the body is materially constituted as a life. Thus, to say that a life is ungrievable means that it neither is materially constituted as a life according to a normative standard nor does that life count. These lives that are not lives, according to the normative standard, are disposable. Their abjection is required to establish what counts as an otherwise grievable life.

In such a way, the death of innumerable civilians at the hands of the United States and its allies in Iraq and Afghanistan are the death of lives that are ungrievable, as their deaths supposedly maintained the security of lives that do matter (Butler 2006b, 2010). To be fundamentally ungrievable means that your life is always prepared for death and never fully socially sustained. 
It means that the norms that maintain the existence of the human require your abjection and your material deprivation. 'Consequently, when such lives are lost they are not grievable, since, in the twisted logic that rationalizes their death, the loss of such populations is deemed necessary to protect the lives of "the living"” (Butler 2010, 31),

Of course, to say that a life is ungrievable is not entirely accurate. When the dead body of a Palestinian child is pulled from a destroyed building because of an Israeli bombardment, we can still see the weeping of the parents and community for that child. However, in a paradoxical sense, this grieving is a non-grieving (Butler 2015a). There are those who grieve but the normative framework prevents this grief from being publicly recognisable as grief. While we can apprehend the sorrow of the Palestinian mother who grieves for her child, recognition of the loss of that child requires a normative reformulation of what lives count as lives and which are disposable.

For Butler, grief can be a 'resource for politics' as it allows us to understand our vulnerability to the other, as well as the other's vulnerability $(2004,23)$. Grief displays 'the thrall in which our relations with others hold us, in ways that we cannot always recount or explain, in ways that often interrupt the self-conscious account of ourselves we might try to provide, in ways that challenge the very notion of ourselves as autonomous and in control' (Butler 2006b, 23). Grief demonstrates our fundamental dependency on the other, as well as how we are made up by the other. When we grieve the loss of the other, we also grieve the loss of the self that the other made up and sustained. Grieving can thus be a resource for a politics of solidarity, when it demonstrates our mutual dependency and vulnerability. When grief for the other is foreclosed, we disavow the possibility of the recognition that one's very existence is dependent on others. 
In this way, the process of grieving is always imbued with power and norms that exceed the subject that grieves (Butler 1997b, 2000). Our inability to grieve some lives publicly is due to the normative disposal of that body through the material practices of abjection. 'The reason that someone will not be grieved, or has already been established as one who is not to be grieved, is that there is no present structure of support that will sustain that life, which implies that it is devalued, not worth supporting and protecting as a life by dominant schemes of value' (Butler 2015a, 197-98).

In other words, because of our constitutive vulnerability, we are always at risk of injury and disposal. When the norms that bring us into social being fail to recognise us as human, we can be deprived of the material conditions needed to sustain our lives without that deprivation being registered as a human deprivation. When we die, that death cannot be registered as the death of a human that must be grieved, because it was not a life that had lived according to the norm. Because the life cannot be grieved, the public is not forced to come to terms with the loss or the normative material conditions that led to it.

As I hope to demonstrate throughout this thesis, the prisoners' body is one that is cast out from the public sphere. It is a body that is judged to have defied the norms of acceptable behaviour within a given society. In this sense, the prisoner is the abject, the constitutive outside of what it means to be a subject of normative society. 
For Butler, 'Condemnation, denunciation, and excoriation work as quick ways to posit an ontological difference between judge and judged, even to purge oneself of another' $(2005,46)$. Just as the abject exist as a repudiated outside to what is normatively accepted, the condemned and the process of condemnation establishes the distinction between the normative and the nonnormative by expelling the non-normative. In this way, "condemnation is very often an act that not only "gives up on" the one condemned but seeks to inflict a violence upon the condemned in the name of "ethics" (Butler 2005, 46). This occurs when we condemn the criminalised person to prison, often giving up on them as a person that is capable of change, to 'protect society' or for the 'greater good'. Therefore, 'every claim we make to the public sphere is haunted by the prison, and anticipates the prison' (Butler 2015a, 185).

This process of condemnation makes the body of the prisoner unrecognisable as a fully human body. In what follows, I examine the death of the prisoner according to the framework I have established here. I demonstrate how the prisoner is discursively and materially constructed and deconstructed, occupying a space at the border of humanisation. I ask how and why it is that the body of the prisoner is differentially allocated precarity and how the vulnerability of the prisoner is heightened and exploited by the prison. Finally, analysing the death of specific people in prisons, I ask not only whether the death of the prisoner, as a condemned category of bodies, is grievable but also what it would mean to mourn the death of the prisoner. 


\section{Conflict and Methods}

Over the past two years I have submitted 49 Official Information Act (OIA) requests to various government agencies, including the Department of Corrections, Ministry of Justice and New Zealand Police. The state has been generally unwilling to give me the information I have requested. It has refused 14 of the 49 requests and has provided me with a response outside of the 20 -working day requirement in 14 instances. Despite this, I have received some crucial information that has both attracted media scrutiny ${ }^{10}$ and has informed the work of prison abolitionist activists and researchers. ${ }^{11}$

Table 1 outlines all the OIA requests I have made, by date, agency from which information was requested, outcome of the request, and whether it was delayed. Where the outcome was 'successful', I received all the information I requested; where it was 'partially successful', I received some but not all the information I requested; where it was 'refused', I received none the information I requested; and where the category is 'information not held', the relevant government agency did not have the information I requested.

Table 1: Official Information Act requests

\begin{tabular}{|l|l|l|l|l|}
\hline Title of request & Date & Agency & Outcome & Delayed \\
\hline $\begin{array}{l}\text { Requests for Prison Transfer for } \\
\text { Transgender Prisoners }\end{array}$ & $21 / 08 / 2015$ & $\begin{array}{l}\text { Department of } \\
\text { Corrections }\end{array}$ & Successful & Yes \\
\hline $\begin{array}{l}\text { LGBTIQ prisoners: Numbers and } \\
\text { policies }\end{array}$ & $02 / 03 / 2016$ & $\begin{array}{l}\text { Department of } \\
\text { Corrections }\end{array}$ & $\begin{array}{l}\text { Partially } \\
\text { successful }\end{array}$ & No \\
\hline $\begin{array}{l}\text { Strip searches in New Zealand } \\
\text { prisons }\end{array}$ & $02 / 03 / 2016$ & $\begin{array}{l}\text { Department of } \\
\text { Corrections }\end{array}$ & Successful & Yes \\
\hline Prison operations manual & $04 / 03 / 2016$ & $\begin{array}{l}\text { Department of } \\
\text { Corrections }\end{array}$ & Refused & No \\
\hline
\end{tabular}

\footnotetext{
${ }^{10}$ See: Pennington's (2016) 'Thousands of strip searches unearth few finds'.

${ }^{11}$ See: No Pride in Prisons' Abolitionist Demands: Toward the End of Prisons in Aotearoa (Lamusse, Morgan, and Rākete 2016).
} 


\begin{tabular}{|c|c|c|c|c|}
\hline $\begin{array}{l}\text { Policy documents concerning LGBTI } \\
\text { prisoners }\end{array}$ & $22 / 06 / 2016$ & $\begin{array}{l}\text { Department of } \\
\text { Corrections and } \\
\text { Minister of } \\
\text { Corrections }\end{array}$ & Successful & Yes \\
\hline Prisoners refurbishing state houses & $22 / 06 / 2016$ & $\begin{array}{l}\text { Housing NZ and } \\
\text { Department of } \\
\text { Corrections }\end{array}$ & Successful & Yes \\
\hline $\begin{array}{l}\text { Programme of work following } \\
\text { inclusion in Auckland Pride } 2016\end{array}$ & $22 / 06 / 2016$ & $\begin{array}{l}\text { Department of } \\
\text { Corrections }\end{array}$ & Successful & No \\
\hline $\begin{array}{l}\text { Training provided to staff with } \\
\text { regard to LGBTI prisoners }\end{array}$ & $22 / 06 / 2016$ & $\begin{array}{l}\text { Department of } \\
\text { Corrections }\end{array}$ & $\begin{array}{l}\text { Information } \\
\text { not held }\end{array}$ & No \\
\hline $\begin{array}{l}\text { Report into Springhill Prison riot of } \\
2016\end{array}$ & $28 / 06 / 2016$ & $\begin{array}{l}\text { Department of } \\
\text { Corrections }\end{array}$ & Refused & No \\
\hline $\begin{array}{l}\text { Review of initial determination of } \\
\text { placement of transgender prisoners } \\
\text { on remand }\end{array}$ & $30 / 06 / 2016$ & $\begin{array}{l}\text { Department of } \\
\text { Corrections }\end{array}$ & Successful & No \\
\hline Contact details for ASCF & $05 / 09 / 2016$ & $\begin{array}{l}\text { Department of } \\
\text { Corrections }\end{array}$ & Refused & No \\
\hline Convictions of transgender prisoners & $05 / 09 / 2016$ & $\begin{array}{l}\text { Department of } \\
\text { Corrections }\end{array}$ & Refused & No \\
\hline Deaths in Corrections' custody & $05 / 09 / 2016$ & $\begin{array}{l}\text { Coronial } \\
\text { Services }\end{array}$ & Successful & No \\
\hline $\begin{array}{l}\text { Number and ethnicity of transgender } \\
\text { prisoners }\end{array}$ & $05 / 09 / 2016$ & $\begin{array}{l}\text { Department of } \\
\text { Corrections }\end{array}$ & $\begin{array}{l}\text { Partially } \\
\text { successful }\end{array}$ & No \\
\hline Security classifications & $05 / 09 / 2016$ & $\begin{array}{l}\text { Department of } \\
\text { Corrections }\end{array}$ & Refused & No \\
\hline Strip searches & $05 / 09 / 2016$ & $\begin{array}{l}\text { New Zealand } \\
\text { Police }\end{array}$ & $\begin{array}{l}\text { Partially } \\
\text { successful }\end{array}$ & Yes \\
\hline Visitation by prison & $05 / 09 / 2016$ & $\begin{array}{l}\text { Department of } \\
\text { Corrections }\end{array}$ & Refused & No \\
\hline $\begin{array}{l}\text { Conditions of confinement at } \\
\text { Auckland Prison }\end{array}$ & $07 / 09 / 2016$ & $\begin{array}{l}\text { Department of } \\
\text { Corrections }\end{array}$ & Refused & No \\
\hline $\begin{array}{l}\text { Double-bunking of transgender } \\
\text { prisons }\end{array}$ & $07 / 09 / 2016$ & $\begin{array}{l}\text { Department of } \\
\text { Corrections }\end{array}$ & Refused & No \\
\hline Total number of prison cells & $07 / 09 / 2016$ & $\begin{array}{l}\text { Department of } \\
\text { Corrections }\end{array}$ & Successful & No \\
\hline Training for strip searches & $07 / 09 / 2016$ & $\begin{array}{l}\text { Department of } \\
\text { Corrections }\end{array}$ & Refused & No \\
\hline Working prisons & $07 / 09 / 2016$ & $\begin{array}{l}\text { Department of } \\
\text { Corrections }\end{array}$ & Refused & No \\
\hline $\begin{array}{l}\text { Name and contact details for all } \\
\text { Prison Directors }\end{array}$ & $25 / 09 / 2016$ & $\begin{array}{l}\text { Department of } \\
\text { Corrections }\end{array}$ & $\begin{array}{l}\text { Partially } \\
\text { successful }\end{array}$ & No \\
\hline $\begin{array}{l}\text { Social workers in New Zealand } \\
\text { prisons }\end{array}$ & $28 / 09 / 2016$ & $\begin{array}{l}\text { Department of } \\
\text { Corrections }\end{array}$ & Successful & Yes \\
\hline Deaths in police custody & $18 / 10 / 2016$ & $\begin{array}{l}\text { New Zealand } \\
\text { Police }\end{array}$ & Successful & Yes \\
\hline COTA reports & $10 / 12 / 2016$ & $\begin{array}{l}\text { Department of } \\
\text { Corrections }\end{array}$ & Refused & No \\
\hline $\begin{array}{l}\text { Sentencing outcome for people held } \\
\text { on remand }\end{array}$ & $20 / 01 / 2017$ & $\begin{array}{l}\text { Ministry of } \\
\text { Justice }\end{array}$ & Successful & No \\
\hline Discipline for sexual activity & $19 / 02 / 2017$ & $\begin{array}{l}\text { Department of } \\
\text { Corrections }\end{array}$ & Successful & Yes \\
\hline
\end{tabular}




\begin{tabular}{|c|c|c|c|c|}
\hline $\begin{array}{l}\text { Advice regarding Department of } \\
\text { Corrections' suicide prevention } \\
\text { strategy }\end{array}$ & $17 / 03 / 2017$ & $\begin{array}{l}\text { Minister of } \\
\text { Corrections }\end{array}$ & $\begin{array}{l}\text { Information } \\
\text { not held }\end{array}$ & No \\
\hline Suicide prevention strategy & $17 / 03 / 2017$ & $\begin{array}{l}\text { Department of } \\
\text { Corrections }\end{array}$ & Successful & Yes \\
\hline Review of directed segregation & $22 / 03 / 2017$ & $\begin{array}{l}\text { Department of } \\
\text { Corrections }\end{array}$ & Refused & Yes \\
\hline $\begin{array}{l}\text { Corrections Amendment Regulations } \\
\text { (No 2) } 2007\end{array}$ & 08/04/2017 & $\begin{array}{l}\text { Minister of } \\
\text { Corrections }\end{array}$ & $\begin{array}{l}\text { Information } \\
\text { not held }\end{array}$ & Yes \\
\hline $\begin{array}{l}\text { Memorandum of understanding } \\
\text { between the Department and } \\
\text { Ministry of Health relating to the } \\
\text { management of prisoners requiring } \\
\text { secondary mental health services and } \\
\text { hospital level care }\end{array}$ & 08/04/2017 & $\begin{array}{l}\text { Department of } \\
\text { Corrections }\end{array}$ & Successful & Yes \\
\hline Inquest into the death of AJL & $18 / 04 / 2017$ & $\begin{array}{l}\text { Coronial } \\
\text { Services }\end{array}$ & $\begin{array}{l}\text { Information } \\
\text { not held }\end{array}$ & No \\
\hline $\begin{array}{l}\text { Prison inspector's report into death } \\
\text { of Nicholas Ward Harris }\end{array}$ & $18 / 04 / 2017$ & $\begin{array}{l}\text { Department of } \\
\text { Corrections }\end{array}$ & Refused & No \\
\hline $\begin{array}{l}\text { Advice to the Chief Executive } \\
\text { regarding Corrections Amendment } \\
\text { Regulations (No 2) } 2007\end{array}$ & $16 / 05 / 2017$ & $\begin{array}{l}\text { Department of } \\
\text { Corrections }\end{array}$ & $\begin{array}{l}\text { Information } \\
\text { not held }\end{array}$ & No \\
\hline Number of people in separates cells & $18 / 05 / 2017$ & $\begin{array}{l}\text { Department of } \\
\text { Corrections }\end{array}$ & Successful & Yes \\
\hline $\begin{array}{l}\text { The number of deaths in prison that } \\
\text { a coroner has found to be a suicide }\end{array}$ & $14 / 06 / 2017$ & $\begin{array}{l}\text { Coronial } \\
\text { Services }\end{array}$ & Successful & No \\
\hline $\begin{array}{l}\text { Average daily prison population } \\
\text { statistics }\end{array}$ & $23 / 06 / 2017$ & $\begin{array}{l}\text { Department of } \\
\text { Corrections }\end{array}$ & $\begin{array}{l}\text { Information } \\
\text { not held }\end{array}$ & No \\
\hline $\begin{array}{l}\text { Overall number of deaths in New } \\
\text { Zealand prisons }\end{array}$ & $23 / 06 / 2017$ & $\begin{array}{l}\text { Coronial } \\
\text { Services }\end{array}$ & Successful & No \\
\hline $\begin{array}{l}\text { Reports into over-representation of } \\
\text { Māori in the criminal justice system }\end{array}$ & $26 / 06 / 2017$ & $\begin{array}{l}\text { Department of } \\
\text { Corrections }\end{array}$ & $\begin{array}{l}\text { Information } \\
\text { not held }\end{array}$ & No \\
\hline $\begin{array}{l}\text { All suicides by sex and ethnicity - } \\
\text { Official Information Act request }\end{array}$ & 02/07/2017 & $\begin{array}{l}\text { Coronial } \\
\text { Services }\end{array}$ & Successful & No \\
\hline $\begin{array}{l}\text { Transforming the management of at- } \\
\text { risk prisoners }\end{array}$ & $18 / 07 / 2017$ & $\begin{array}{l}\text { Department of } \\
\text { Corrections }\end{array}$ & $\begin{array}{l}\text { Information } \\
\text { not held }\end{array}$ & Yes \\
\hline $\begin{array}{l}\text { Compassionate release, broken down } \\
\text { by financial year }\end{array}$ & $28 / 07 / 2017$ & $\begin{array}{l}\text { Department of } \\
\text { Corrections }\end{array}$ & Successful & No \\
\hline $\begin{array}{l}\text { Directed segregation and ARU } \\
\text { numbers }\end{array}$ & $28 / 07 / 2017$ & $\begin{array}{l}\text { Department of } \\
\text { Corrections }\end{array}$ & Pending & Yes \\
\hline Number of deaths in police custody & $28 / 07 / 2017$ & $\begin{array}{l}\text { Coronial } \\
\text { Services }\end{array}$ & $\begin{array}{l}\text { Partially } \\
\text { Successful }\end{array}$ & No \\
\hline $\begin{array}{l}\text { Reducing Reoffending Through } \\
\text { Employment -- presentation by } \\
\text { Elizabeth Manchee }\end{array}$ & $28 / 07 / 2017$ & $\begin{array}{l}\text { Department of } \\
\text { Corrections }\end{array}$ & Successful & No \\
\hline $\begin{array}{l}\text { Work on income and employment of } \\
\text { prisoners prior to incarceration }\end{array}$ & $14 / 08 / 2017$ & $\begin{array}{l}\text { Department of } \\
\text { Corrections }\end{array}$ & Pending & Pending \\
\hline Prisoners and election day & $16 / 08 / 2017$ & $\begin{array}{l}\text { Department of } \\
\text { Corrections }\end{array}$ & Refused & No \\
\hline
\end{tabular}


Collecting data through OIA requests can both take considerable time and lead to very limited results if the relevant agency is unwilling to cooperate or the Office of the Ombudsman - the authority that oversees OIA requests ${ }^{12}$ - has not required them to cooperate. That means OIA research requires casting wide nets and hoping to find something. This method is what led to the important data I now hold detailing deaths in custody. Although I have had a long-standing interest in deaths in custody, following an OIA request on this topic to Corrections, I was reminded of the fact that the Coronial Office is required to open an inquiry into every death that occurs in New Zealand prisons. Following the inquiry, the coroner makes a finding. These findings are effectively reports from coroners about the death.

On September 5, 2016, I requested every report made by the Coronial Office into deaths in prisons. Nine days later, the Office informed me they would provide me with the data and a CD arrived a week or so later with the reports. On February 22, 2017, I requested all findings that had been completed since September 5, 2016 and received an additional 5 reports that same day.

In total, Coronial Services provided me with 113 reports. I have findings from deaths dating from July 1, 2007 to June 30, 2016, as the reporting system began in July 2007. The most recent report I have was completed for a death that happened on May 1, 2016. I do not have any findings into deaths occurring after May 1, 2016, as it can sometimes take years for inquiries and findings to be completed. In information provided to me under the Official Information Act by the Coronial Office (Kelly 2017a), 9.09\% of cases from fiscal year 2012/13, 7.69\% of

\footnotetext{
${ }^{12}$ Under the authority granted to it in the Official Information Act 1982.
} 
cases from $2013 / 14,41.18 \%$ of cases from $2014 / 15,88.46 \%$ of cases from $2015 / 16$, and $88.24 \%$ of cases from $2016 / 17$ are still 'active', as of July $11,2017 .{ }^{13}$ Where the case is active, there is not yet a coroner's finding. Of the deaths between July 1, 2007 and June 30, 2016, the period for which I have findings, $22.22 \%$ of all cases are still active. In other words, I do not have a finding into every death in New Zealand prisons between July 2007 and June 2016, as approximately one fifth of cases from that period do not have a completed finding.

Part of the importance of this data is that no one has analysed this particular set of cases before. Although some of the deaths have been publicly reported, as I understand it, I am the first person to acquire and analyse this data on such a large scale. Because these reports go well beyond names and cause of death, this data is incredibly rich and holds insights into prison deaths that have not been exposed in Aotearoa before. This particularity and richness necessarily shapes the methods I use to analyse the data. I have a mixed-methods approach, using both descriptive statistics and critical discourse analysis.

\section{Quantitative analysis of death in prisons}

I do not use descriptive statistics to prove causation between certain types of death and other factors, or even as a source from which to draw major conclusions. Instead, I use them to provide context and an understanding of the population that is affected by prison deaths. As this thesis is concerned with the grievability of prisoners' deaths, I am not interested in providing policy 'solutions' to address my findings, nor do I make causal arguments about race,

\footnotetext{
13 There have been, according to the statistics in the OIA provided to me on July 11, 2017, a small number of findings published since I requested the findings from the Coronial Office. For reasons of time, I cannot include those further cases in my analysis.
} 
gender, and particular practices leading up to deaths in custody. For that reason, the statistics I use remain basic, providing essential demographic and other information, quantitatively analysed with averages, percentages and graphs.

I provide the quantitative analysis and context for two key reasons. First, the data I have is both unique and important. Other scholars have not published quantitative analysis of coroners' findings into prison deaths in New Zealand in this period. ${ }^{14}$ Consequently, I am responsible for providing some of that groundwork, as I have data that has not been analysed before. Second, while my qualitative analysis weaves between cases, the quantitative analysis outlines a structural context about who is affected by prison death. This, in turn, informs my qualitative analysis.

Although I received 113 cases from the Coronial Office, I exclude 5 of these cases from my analysis. That is because they are cases about people who have died in Corrections' custody outside of the prison, on home detention for example, or involved the death of a prison guard. As these people were not prisoners at their time of death, I do not analyse the findings into their deaths. This means I have a total of 108 coroner's findings to analyse.

Tables 2 and 3 outline the various data I collected from the coroner's findings. I established 46 categories of data from across the findings. I formed these categories through both an inductive process, once I had read all the findings for the first time, and from both New Zealand and

\footnotetext{
${ }^{14}$ I do note however, that two government commissions into prison suicide were established in the mid-1990s that investigated some coroners' findings (Le Quesne 1995; Gardiner et al. 1996). Cox and Skegg (1993b, 1993a) also analyse prison suicides over a similar time-period in their research.
} 
international literature on prison deaths. I established some categories, such as double-bunked status, because of my work on prisons and with prisoners outside of the scope of this thesis.

I do not provide analysis in this thesis of all the categories for which I gathered data. This is for several reasons. In some cases, there is simply not enough data for me to analyse, while in others I am not confident the data is reliable because of the differing ways that coroners provide the information. I also gathered more data that I could analyse in this thesis, meaning I had to prioritise the inclusion of some data over other data which was not as closely linked to the purpose of the thesis. In cases where I gathered the data for categorising purposes only, such as the name of the deceased, I do not further analyse it.

In the 'Method of Analysis' column of Tables 2 and 3, where I state, 'data not analysed', I collected the data but do not analyse it, for the reasons above. The 'number of data entries' refers to the number of entries that were ascertainable from the coroners' findings for each category. I briefly outline the purpose of collecting each data type in the tables, but provide more reasoning in the following chapters. 
Table 2: Methods of quantitative analysis of coroners' findings (analysed)

\begin{tabular}{|c|c|c|c|c|}
\hline Data type & Method of analysis & $\begin{array}{c}\text { Number of data } \\
\text { entries }\end{array}$ & Purpose & $\begin{array}{l}\text { Section } 71 \\
\text { applies }\end{array}$ \\
\hline $\begin{array}{l}\text { Coroner prefers Corrections' evidence } \\
\text { over family evidence }\end{array}$ & Percentages & 15 & To analyse whose evidence the coroners prefer. & No \\
\hline Date of Birth & Mean, median & 99 & To calculate average ages and population analysis. & No \\
\hline Date of Death & None & 108 & $\begin{array}{l}\text { To calculate the length of time in prison and the deceased's age } \\
\text { at death. }\end{array}$ & No \\
\hline Days Alive & Median, range & 98 & To find the exact ages of deceased, compared across death-type. & No \\
\hline Days in prison & Median, range & 80 & To compare number of days in prison across death-type. & No \\
\hline Exact Age & Median, range & 108 & $\begin{array}{l}\text { This used the 'days alive' data to find the exact number of years, } \\
\text { months and days a person had been alive. }\end{array}$ & No \\
\hline Family condolences & $\begin{array}{l}\text { Percentages, } \\
\text { categorisation }\end{array}$ & 108 & To compare expression of condolences across data types. & No \\
\hline Family contradicts Corrections & Percentages & 108 & To demonstrate conflict within the findings. & No \\
\hline Family lawyer mentioned & $\begin{array}{l}\text { Percentages, } \\
\text { categorisation }\end{array}$ & 108 & $\begin{array}{l}\text { To compare whether a family lawyer was mentioned or not } \\
\text { across other data types. }\end{array}$ & No \\
\hline First time in prison (self-inflicted death) & Percentages & 3 & $\begin{array}{l}\text { To determine if first-time prisoners are disproportionately like to } \\
\text { cause self-inflicted death. }\end{array}$ & Yes \\
\hline Held in ARU during death & $\begin{array}{l}\text { Percentages, } \\
\text { categorisation }\end{array}$ & 108 & To compare ARU status at death across other data types. & Yes \\
\hline Howard League mentioned & $\begin{array}{l}\text { Percentages, } \\
\text { categorisation }\end{array}$ & 108 & $\begin{array}{l}\text { To compare whether a Howard League representative was } \\
\text { mentioned or not across other data types. }\end{array}$ & No \\
\hline Natural or unnatural death & $\begin{array}{l}\text { Percentages, } \\
\text { categorisation }\end{array}$ & 108 & To compare death type across other data types. & No \\
\hline Nature of offending mentioned & $\begin{array}{l}\text { Percentages, } \\
\text { categorisation }\end{array}$ & 108 & To compare mention of nature of offending across data types. & No \\
\hline Number of recommendations & Mean & 25 & $\begin{array}{l}\text { To find the average number of recommendations, where they are } \\
\text { made. }\end{array}$ & No \\
\hline Occupation & Percentages & 108 & To analyse how the coroners account for prisoners as workers. & No \\
\hline Page count & Mean, Median & 108 & To compare average page counts across data type. & No \\
\hline Prison Start & None & 76 & To calculate the length of time in prison. & No \\
\hline
\end{tabular}




\begin{tabular}{|c|c|c|c|c|}
\hline Recommendations made & $\begin{array}{l}\text { Percentages, } \\
\text { categorisation }\end{array}$ & 108 & $\begin{array}{l}\text { To compare whether recommendations were made across other } \\
\text { data types. }\end{array}$ & No \\
\hline Remand type & $\begin{array}{l}\text { Percentages, } \\
\text { categorisation }\end{array}$ & 28 & To analyse death-type according to sentenced or remand type. & No \\
\hline$\S 71$ Applies & $\begin{array}{l}\text { Percentages, } \\
\text { categorisation }\end{array}$ & 108 & $\begin{array}{l}\text { To ensure that no information restricted under } \S 71 \text { of the } \\
\text { Coroners Act is published. }\end{array}$ & $\mathrm{N} / \mathrm{A}$ \\
\hline Self-inflicted death & $\begin{array}{l}\text { Percentages, } \\
\text { categorisation }\end{array}$ & 108 & To compare self-inflicted death status across other data types. & No \\
\hline Sentenced or remand & $\begin{array}{l}\text { Percentages, } \\
\text { categorisation }\end{array}$ & 108 & To analyse death-type according to sentenced or remand status. & No \\
\hline Sex (of prison) & $\begin{array}{l}\text { Percentages, } \\
\text { categorisation }\end{array}$ & 108 & To provide a gendered analysis of quantitative data. & No \\
\hline Suicide or Accident & $\begin{array}{l}\text { Percentages, } \\
\text { categorisation }\end{array}$ & 40 & $\begin{array}{l}\text { To compare suicide or accident death status across other data } \\
\text { types. }\end{array}$ & Yes \\
\hline Unit type & $\begin{array}{l}\text { Percentages, } \\
\text { categorisation }\end{array}$ & 108 & $\begin{array}{l}\text { To compare proportion of deaths in different across other data } \\
\text { types. }\end{array}$ & Yes \\
\hline Word count & Mean & 108 & To compare average word counts across data types. & No \\
\hline Yearfrac & Median & 99 & $\begin{array}{l}\text { Yearfrac is a Microsoft Excel function that enables me to } \\
\text { calculate the exact age in years of the deceased. }\end{array}$ & No \\
\hline
\end{tabular}

Table 3: Methods of quantitative analysis of coroners' findings (not analysed)

\begin{tabular}{|c|c|c|c|c|}
\hline Data type & $\begin{array}{l}\text { Method of } \\
\text { analysis }\end{array}$ & $\begin{array}{c}\text { Number of data } \\
\text { entries }\end{array}$ & Purpose & $\begin{array}{l}\text { Section } 71 \\
\text { applies }\end{array}$ \\
\hline $\begin{array}{l}\text { Assessed at risk at death (self- } \\
\text { inflicted) }\end{array}$ & $\begin{array}{l}\text { Data not } \\
\text { analysed }\end{array}$ & 19 & $\begin{array}{l}\text { To assess whether being considered 'at-risk' by Corrections prevents self- } \\
\text { inflicted deaths. }\end{array}$ & Yes \\
\hline $\begin{array}{l}\text { Assessment of healthcare (natural } \\
\text { deaths) }\end{array}$ & $\begin{array}{l}\text { Data not } \\
\text { analysed }\end{array}$ & 70 & $\begin{array}{l}\text { To analyse how the coroners describe healthcare conditions for those who } \\
\text { died of natural deaths. }\end{array}$ & $\mathrm{N} / \mathrm{A}$ \\
\hline Case Number & $\begin{array}{l}\text { Data not } \\
\text { analysed }\end{array}$ & 108 & Categorisation. & No \\
\hline Coroner & $\begin{array}{l}\text { Data not } \\
\text { analysed }\end{array}$ & 108 & Categorisation. & No \\
\hline Date of Attempt & $\begin{array}{l}\text { Data not } \\
\text { analysed }\end{array}$ & 37 & $\begin{array}{l}\text { To calculate the length of time in prison prior to attempted self-inflicted } \\
\text { death. }\end{array}$ & No \\
\hline
\end{tabular}




\begin{tabular}{|c|c|c|c|c|}
\hline Days to Attempt & $\begin{array}{l}\text { Data not } \\
\text { analysed }\end{array}$ & 28 & $\begin{array}{l}\text { To find the average and range in length of time between entry to prison a } \\
\text { self-inflicted death attempt. }\end{array}$ & No \\
\hline $\begin{array}{l}\text { Days until next court appearance } \\
\text { (self-inflicted deaths) }\end{array}$ & $\begin{array}{l}\text { Data not } \\
\text { analysed }\end{array}$ & 14 & $\begin{array}{l}\text { To calculate the average number of days between next court appearance of } \\
\text { remand-self-inflicted deaths and the death. }\end{array}$ & No \\
\hline Double bunked (self-inflicted) & $\begin{array}{l}\text { Data not } \\
\text { analysed }\end{array}$ & 11 & $\begin{array}{l}\text { To compare double-bunked status of self-inflicted death to general prison } \\
\text { population. }\end{array}$ & Yes \\
\hline Held in ARU before death & $\begin{array}{l}\text { Data not } \\
\text { analysed }\end{array}$ & 108 & To compare ARU status prior to death across other data types. & Yes \\
\hline Layperson's cause of death & $\begin{array}{l}\text { Data not } \\
\text { analysed }\end{array}$ & 108 & Categorisation. & Yes \\
\hline $\begin{array}{l}\text { Length of time between stay in } \\
\text { ARU and death }\end{array}$ & $\begin{array}{l}\text { Data not } \\
\text { analysed }\end{array}$ & 9 & $\begin{array}{l}\text { To analyse the relationship between length of time out of the ARU and } \\
\text { death. }\end{array}$ & Yes \\
\hline Lock up attempt (self-inflicted) & $\begin{array}{l}\text { Data not } \\
\text { analysed }\end{array}$ & 15 & $\begin{array}{l}\text { To analyse the proportion of self-inflicted deaths that occur during prison } \\
\text { lock up. }\end{array}$ & Yes \\
\hline Name & $\begin{array}{l}\text { Data not } \\
\text { analysed }\end{array}$ & 108 & Categorisation. & No \\
\hline Prison & $\begin{array}{l}\text { Data not } \\
\text { analysed }\end{array}$ & 108 & Comparing prisons and categorisation. & No \\
\hline Prison Inspector & $\begin{array}{l}\text { Data not } \\
\text { analysed }\end{array}$ & 108 & Categorisation. & No \\
\hline $\begin{array}{l}\text { Referred to as 'future focussed' } \\
\text { (self-inflicted death) }\end{array}$ & $\begin{array}{l}\text { Data not } \\
\text { analysed }\end{array}$ & 16 & $\begin{array}{l}\text { To find the proportion of self-inflicted deaths where the deceased was } \\
\text { considered 'future-focussed' at death. }\end{array}$ & Yes \\
\hline $\begin{array}{l}\text { Remand days following court } \\
\text { appearance or news }\end{array}$ & $\begin{array}{l}\text { Data not } \\
\text { analysed }\end{array}$ & 18 & $\begin{array}{l}\text { To calculate the average number of days between last court appearance or } \\
\text { case news of remand-self-inflicted deaths and the death. }\end{array}$ & No \\
\hline Stated cause of death & $\begin{array}{l}\text { Data not } \\
\text { analysed }\end{array}$ & 108 & Categorisation. & Yes \\
\hline
\end{tabular}


All cases of 'self-inflicted' death are potentially subject to a censorship regime, under section 71 of the Coroners Act 2006. Section 71 of the Coroners Act, as it currently stands, prohibits the publication without a coroner's permission any detail of self-inflicted death that may suggest the method of death. However, for deaths that occurred prior to July 22, 2016, an older version of the Coroners Act applies. This version of section 71 states that once a coroner has found a death to be self-inflicted, no one can, without a coroner's permission, 'make public a particular of the death other than - (a) the name, address, and occupation of the person concerned; and (b) the fact that the coroner has found the death to be self-inflicted'. ${ }^{15}$ This is a more restrictive regime than the current regime. The previous version of section 71 applies to all cases I have received.

On two occasions, I wrote to Coronial Services requesting the authority to publicise details that were restricted under section 71 . The first time I wrote to Chief Coroner Deborah Marshall, asking her to provide me with the permission under her new authority in section 71A of the Coroners Act to grant an exemption to suspend section 71. Her office replied: 'Section 71A only applies to deaths that occurred after July 2016 so you are unable to make such an application' (Andrews 2017, n.p.).

As a result, I wrote to Coronial Services again under the pre-July 2016 provisions. This provides me with the ability to publish these details, under section $71(2)$, if I receive 'a coroner's authority or permission'. I, therefore, requested the permission from any coroner for the right to publish these details. Unfortunately, I never received a response from Coronial

\footnotetext{
15 The version of the Act to which I refer is available here: http://www.legislation.govt.nz/act/public/2006/0038/43.0/DLM377809.html
} 
Services to my second letter. This means the censorship regime applies to my thesis, restricting what I can and cannot say about self-inflicted custodial deaths.

What matters, therefore, is what exactly is censored. The degree of censorship depends on the interpretation of the phrase 'particulars of the death'. The Law Commission finds coroners themselves are divided as to the meaning of restrictions and there 'is much uncertainty about what exactly is restricted under the current provisions' $(2014,5)$. The Ministry of Health, in its recommendations to media on suicide reporting, notes the 'Chief Coroner has commented that he considers any "particular" relating to the manner of death includes the method, the cause of death and circumstances leading up to the death. "Particulars" would therefore include mental health history, other potential causal factors involved in the death and the circumstances leading up to the death' $(2011,10)$. This is the interpretation I have adopted for my analysis.

As such, the final column of Tables 2 and 3 indicates whether I consider the categories to be a 'particular' of the death, and therefore restricted from publication under section 71 of the Coroners Act. Those categories include categories that are explicitly mentioned as 'particulars', such as whether it was a suicide, as well as some of the material circumstances that the deceased experienced at the time of death. All other data is either demographic or does not relate to the circumstances leading up to the death, or the method of death. These restrictions also apply to my qualitative analysis. Although, I will outline my qualitative methods in greater detail below, I note that in some occasions I quote from coroners' findings into self-inflicted deaths. I cannot, however, provide qualitative analysis of the particulars of the deaths where section 71 applies. 
Further, section 74 of the Coroners Act empowers coroners to censor evidence from an inquiry, if the coroner is 'satisfied that it is in the interests of justice, decency, public order, or personal privacy to do so'. It is not uncommon for coroners to censor the name or a particular detail of evidence under section 74 . These selective censorships have not affected my quantitative analysis. However, in one case, the coroner censors all aspects of the findings. I cannot provide any quantitative or qualitative analysis of that case.

Most of my analysis relates to data from the coroner's findings. However, I have a received several Official Information Act request responses relating to deaths in prisons that also require some basic quantitative analysis.

\section{Critical, materialist discourse analysis}

For the most part, this thesis is a qualitative analysis of the death of the prisoner, and their grievability. I employ a critical discourse analysis (CDA) to do this. The objective of CDA is described by one of its founders, Norman Fairclough, as developing 'ways of analysing language which address its involvement in the workings of contemporary capitalist society' $(2010,1)$. As CDA generally aims to demonstrate, language is not a neutral medium of communication. It is essential to the production and reproduction of social and economic structures that simultaneously enrich and immiserate different populations. 
CDA differs from merely descriptive analysis, such as that which I provide in my quantitative analysis, in that it aims to uncover the ideological workings even within that quantitative analysis. The critical discourse 'analyst differentiates ideology from knowledge, i.e. unless $\mathrm{s} / \mathrm{he}[\mathrm{sic}]$ is aware of the ideological dimensions of discourse, the chances are that $\mathrm{s} / \mathrm{he}$ will be unconsciously implicated in the reproduction of ideologies, much as the lay subject is' (Fairclough 2010, 46-47). Instead of accepting the data, as provided by Coronial Services, I therefore treat the findings as ideological texts produced by what Althusser (2001) refers to as an Ideological State Apparatus.

CDA is not a unified or singular methodology and has different and contradictory approaches. Many critical discourse analysts are, nonetheless, theoretically informed by Althusser's (2001) understanding of ideology. In his 'Ideology and Ideological State Apparatuses', Althusser (2001) argues that social formations require the reproduction of the conditions of their own production, otherwise they will cease to exist. For Althusser, social formations reproduce themselves, in part, through ideology as produced through Ideological State Apparatuses (ISAs). As well as apparatuses, like education, which are often controlled by the state, ISAs include institutions that may otherwise be considered 'non-state' apparatuses such as media and the family, as they function in support of and are constructed and authorised through capitalist state power. Ideology represents 'the (imaginary) relationship between individuals to the relations of production and the relations that derive from them' (Althusser 2001, 168).

Although there are multiple, contradictory ideologies informing any text, the ideology that concerns CDA scholars is the dominant ideology within any given discourse, the 'ideology of the ruling class' (Althusser 2001, 185). For Chiapello and Fairclough, 'ideology is a system 
of ideas, values and beliefs oriented to explaining a given political order, legitimizing existing hierarchies and power relations and preserving group identities' $(2010,257)$. Ideology is important for CDA as, when exposed, it demonstrates the distortions and naturalisations that help to reproduce submission to the existing relations of production.

This concept of ideology shapes what is meant by 'discourse' within Critical Discourse Analysis. Fairclough $(2010,2012)$ demonstrates two distinct meanings of discourse in CDA. First, discourse refers to 'semiotic elements (as opposed to and in relation to other, nonsemiotic, elements) of social life (language, but also visual semiosis, "body language" etc)' (Fairclough 2012, 453). Second, discourse or plural discourses also refer to 'ways of construing aspects of the world (physical, social or mental) which can generally be identified with different positions or perspectives of different groups or social actors' (Fairclough 2010, 232).

This, however, does not mean there is an equality of discourses, all of which are equally important and which provide different 'perspectives' or 'lenses' of analysis. As we live in a social formation based on economic exploitation that creates differential outcomes for people dependent on class, race, gender, sexuality and other social structures, there will be dominant discourses - the ideology of the ruling class, to use Althusser's language - which are essential to the ideological reproduction of the social formation. As I demonstrate in the following chapters, discourses of criminalisation, vilification, and security dominate coroners' findings of deaths in prison. 
Because of its ideological functioning, discourse cannot be studied independently, separated from the social formation in which it arises. For Fairclough, CDA 'is not analysis of discourse "in itself" as one might take it to be, but analysis of dialectical relations between discourse and other objects, elements or moments, as well as analysis of the "internal relations" of discourse' (2010, 4, emphasis original). CDA requires a material analysis of a text and its relationship to the social formation, which 'allows us to appreciate the broader political context, as well as material implications' (Ainsworth and Hardy 2004, 239). This inseparable relationship between discourse and social relations requires the analyst to consider how the text or discourse being analysed relates to the modes of domination in which it arises (Fairclough 2010; McKenna 2004). For CDA, 'the question of how discourse cumulatively contributes to the reproduction of macro structures is at the heart of the explanatory endeavour' (Fairclough 2010, 45).

In this way, the 'critical' element of critical discourse analysis requires a demonstration of the role that a given text plays within a larger social formation (Fairclough 2010; Graham and Luke 2011; McKenna 2004; Kress 1996; Luke 1995; Fairclough 2012; Wodak 2011). However, the best CDA does not do only this. For some, inspired by Marx's $(1976 \mathrm{~b}, 5) 11^{\text {th }}$ thesis on Feuerbach - 'the philosophers have only interpreted the world in various ways; the point is to change it' - CDA not only attempts to understand but also change the exploitative relations from which a text arises. In this way, CDA has a 'political project' (Kress 1996, 15).

It is not possible to provide an account for the material conditions in New Zealand prisons without that account being inflected through dominant or other ideologies. As a result, I can either adopt or presuppose the dominant ideologies of the prison, or provide a critical analysis 
of how that ideology is reproduced in the texts I analyse. This analysis presupposes that the prison is an essential ideological and repressive apparatus that helps to maintain settlercolonial capitalism. Any analysis that does not account for the relations of domination intrinsic to the prison risks reproducing ruling class ideologies that imprisonment is both necessary and correctional. For this reason, I take the settler-colonial capitalist domination enforced through the prison as the social condition in which these texts arise. This analysis is thus positioned in opposition to this domination and its naturalisation in texts such as the coroners' findings.

Given this orientation, my specific method is one informed by Marx's method of textual analysis. In their analysis across Marx's oeuvre, Fairclough and Graham argue that language critique is 'central to Marx's approach; an historical, materialist, critical understanding of language is the very foundation of his method' $(2010,316)$. Further, Fairclough and Graham state that Marx demonstrates 'dialectical interconnectivity of language and other elements of the social' without reducing everything to language, 'removing language from material existence, or reifying language' $(2010,303)$.

They show how, in Marx's engagement with bourgeois political economy and German idealist texts, he uncovers the dialectical relationship between these texts and the social formation in which they arise. Marx's analysis of bourgeois political economy texts, in particular, points to 'a critical analysis of the whole formal and conceptual architecture and texture of political economy texts, focusing on texts as relational work, texts as producing certain relations and not producing others, as foregrounding selected elements of those relations, as well as their 
being produced from within certain relations and not from within others' (Fairclough and Graham 2010, 328).

For Marx, the analysis of language is, of course, a materialist analysis. As I argue in the first chapter, a complete distinction between materiality and language cannot hold, as a language itself must be materially produced by subjects and we can only access materiality through language. The language that we use to explain the world around us is provided to us by that world, while also partially constituting that world. As Marx and Engels argue, the 'production of ideas, of conceptions, of consciousness, is at first directly interwoven with the material activity and the material intercourse of men [sic] - the language of real life' $(1976,36)$.

The kind of materialist CDA avant la lettre that Marx (1976a) employs, and that I aim to replicate, is his deconstruction of Factory Inspectors' reports in Capital: A Critique of the Political Economy, Volume 1. In his analysis of the working day, Marx uses the Factory Inspectors' reports, alongside other official reports, to detail the material conditions that workers experienced at the time. Quoting extensively from the reports, Marx demonstrates how within the language of the Inspectors themselves, the incremental lengthening of the working day, such as cutting into meal breaks, is an inevitable part of the insatiable drive to extract surplus value. In this way, through his analysis of the reports in relation to his examination of the capitalist mode of production, he leads the Inspectors to conclusions they could otherwise not reach. 
Marx (1976a) also demonstrates how the categories used by Inspectors to describe adult ('fulltimers') and child ('half-timers') labourers emerges from a particular mode of production. In a mode of production where a worker sells their labour-power, 'the designation of the workers who work full time as "full-timers", and the children under 13 who are only allowed to work six hours as, "half-timers",' means the 'worker is here nothing more than personified labourtime' (Marx 1976a, 352-53). In this way, the Factory Inspectors reports contribute to the discursive production of workers as merely commodified labour-power to be employed and disposed of at the will of the capitalist.

Marx's analysis draws widely from official sources. However, the purpose is to not merely reproduce the findings of the reports, but to recontextualise them within a materialist analysis of capitalism. Marx draws on the relations between the texts, the social formation and bourgeois political economic dogma. In this sense, while Marx is certainly interested in the words that are used, the purpose is not to be "at war with "phrases"' (Fairclough and Graham 2010, 315). Instead, he necessarily engages with official discourses, as a conduit of information pertaining to material conditions, as well as exposing the ideological nature of those discourses and absences within them.

I hope to replicate Marx's method of discourse analysis as described above. The purpose of my analysis is not to engage in a 'war with phrases', merely critiquing words used by coroners. This is certainly not an effort to encourage coroners to improve the language they use or to make them appear more compassionate. My analysis intends to uncover some of the dire material circumstances that incarcerated people in Aotearoa experience and draw connections between the texts, the prison system, the social formation, and ideology in which they arise. 
My analysis is also, clearly, influenced by Butler's methods of analysis and the theoretical frameworks she provides to understand texts. In this way, I also analyse how the coroners' findings reproduce norms of dehumanisation and abjection, as well as the construction and destruction of the subjects of these norms. I draw on Butler's work to understand the constitutive outside and founding repudiations that enable the production of coroners' findings. The framework I provide in chapter 1 thus shapes my deconstruction of these texts.

Recognising that this CDA is influenced by Marx, Butler, and others, in what follows I outline the specific CDA tools I employ in my analysis. First, part of Butler's project is to demonstrate how certain ideas or social phenomena are naturalised or taken for granted. A key component of CDA is its efforts to denaturalise what is generally considered as background knowledge or 'common sense' (Luke 1995, 20; Fairclough 2010, 30). Fairclough argues that the role of dominant 'ideological-discursive formations' is 'to "naturalize" ideologies, i.e. to win acceptance for them as non-ideological "common sense" (2010, 30). CDA attempts to denaturalise, 'disarticulate and to critique texts as a way of disrupting common sense' (Luke 1995, 20). For Fairclough, 'denaturalization involves showing how social structures determine properties of discourse, and how discourse in turn determines social structures' $(2010,30)$.

Denaturalisation is an important element of CDA because the naturalisation of certain ideas through discourse is a means for the 'disguise of power relations that are tied to inequalities in the social production and distribution of symbolic and material resources' (Luke 1995, 12). 
If CDA is centrally concerned with understanding and transforming social formations, the denaturalisation of social processes is essential to understanding what exactly needs to be transformed and where the issues lie.

Second, a dialectical analysis of discourse rejects the proposition that there is a singular, coherent discourse that fully determines all aspects of a discursive formation. Instead, it presupposes a multiplicity of discourses, highlighting the contradiction between and within given discourses. While there are certainly dominant discourses, some of which may even seem almost entirely inevitable, a dialectical CDA uncovers the contradictions and points of weakness that render it capable of being transformed. In my analysis, I expose contradictions within the logics of the discourses espoused in the coroners' findings and find conclusions to those logical contradictions that exceed any individual coroner's text.

Third, I demonstrate the intertextuality of the texts. 'Intertextuality reveals how texts draw upon, incorporate, recontextualize, and dialogue with other texts as well as those that are left out' (McKenna 2004, 11). Texts do not stand alone but always exist in relation to a world of other texts. They always draw on a chain of language and discourse to be understandable as a text. This means that my analysis of these reports cannot be isolated as single findings, but analysed in relation to the other findings, the policy documents that surround them, and the broader social and economic relations.

Fourth, just as dominant discourses naturalise certain ideologies, they render certain ideas silent. CDA, thus, gives voice to those silences, noting what is impossible within the dominant 
discourse. Fairclough and Graham (2010) argue that Marx does this in his critique of bourgeois political economy. Marx demonstrates how bourgeois political economists cannot adequately account for the necessary exploitation of workers in capitalism, because such an account would disrupt the appearance of coherency of the ruling class ideology they espouse. It is left to Marx to follow their concepts to their conclusions, showing what is impossible within the discourse of bourgeois political economists but nonetheless haunts their work.

In a concrete sense, every text is limited in what it can say. The text draws on a vocabulary, grammar, genre and style that exceed it. Broadly, each 'discursive formation (such as science, law, medicine, engineering) puts limits on the epistemic, subjective, and ethical bases within which a range of possible statements is possible' (McKenna 2004, 14). Within the specific genre of coroners' findings, there are limitations on the scope of investigation and recommendations as outlined in the Coroners Act. There are also stylistic expectations of formality of the findings, as they are equivalent to a written ruling by a judge. As noted above, sections 71 and 74 establish a regime of censorship, restricting what information can be made public. However, it is the limiting and silencing effects of the ruling ideology reproduced in these findings that is of greatest importance here, as it makes certain forms of speech ‘impossible speech’ (Butler 1997a, 133).

Finally, I use CDA to answer the questions I ask in chapter 1. It is, in part, through these texts and the discourses they reproduce that the meaning of the category of 'prisoner' is established. Of course, what it means to be a prisoner, and the material social conditions that lead someone to prison, are not determined simply by how we talk about them. These texts do, however, represent and reify some of the material conditions of confinement. Both those material 
conditions and the ideological representation of them remain essential to answering the following questions: How is the prisoner constructed as a subject? Is the life of a prisoner recognisable as a human life? Is the death of the prisoner grievable? What does it mean to grieve the prisoner's death?

\section{Coroners and custodial death}

Before I proceed to my analysis, I need to provide some further context around coroners' inquests and findings, as well as some theoretical framing of the inquests and findings. As I mention above, under section 60(1) of the Coroners Act 2006, coroners are required to open an inquiry into any death in 'official custody', which includes the death of a prisoner. If the coroner is satisfied that they do not need to receive oral evidence, they can hold a 'hearings on papers'. This is where the coroner makes their finding in their office, having read all the evidence. This is not a public hearing. However, if the coroner determines that they need to hear from witnesses in person, they hold an inquest in the Coroners Court, which is usually open to the public (Coronial Services 2016b). ${ }^{16}$ Unlike other jurisdictions, such as England and Wales, coroners' inquests in New Zealand are not held before a jury, only a coroner. ${ }^{17}$

The purpose of the coroner's investigation, as outlined in section 4(2)(a) of the Coroners Act 2006, is to 'establish, so far as possible - (i) that a person has died; and (ii) the person's identity; and (iii) when and where the person died; and (iv) the causes of the death; and (v) the circumstances of the death'. Coroners are additionally empowered 'to make recommendations or comments under section $57 \mathrm{~A}$ that, in the coroner's opinion, may, if

\footnotetext{
${ }^{16}$ As required under section 85(1) of the Coroners Act 2006.

${ }^{17}$ As required under section 82 of the Coroners Act 2006.
} 
drawn to public attention, reduce the chances of the occurrence of other deaths in circumstances similar to those in which the death occurred'. The coroner conducts the inquest and can cross-examine witnesses, if they choose to do so. ${ }^{18}$ At the conclusion of the inquiry or inquest, the coroner writes a finding, which outlines the facts of the death, as well as any recommendations, comments, or restrictions on publication.

As Coroner Matenga notes, the 'jurisdiction of the Coroners Court is unlike any other within the New Zealand judicial system. The jurisdiction is inquisitorial not adversarial' (2015, para. 6). ${ }^{19}$ This means that the inquiry is supposed to be a 'fact finding mission' that does not apportion guilt or liability (Shortland 2011, para. 6). While this is the official account of coroners' inquiries, the official account cannot fully attest to the role of coroners' inquiries into custodial death. As international literature (Scraton and Chadwick 1986; Beckett 1999; Razack 2011), as well as my findings suggest, coroners' inquiries are also a site of conflict.

This conflict emerges in multiple ways throughout the findings. There are conflicting narratives, conflicting interests, and conflicting evidence. While coroners sometimes note conflicting evidence between officials and families, the depiction of the inquiries as neutral fact-finding endeavours further naturalises the state's account for the death as the official account. While coroners stress their impartiality in determining the facts of death, their findings remain fundamentally partial and incomplete.

\footnotetext{
${ }^{18}$ As allowed under section 88(b) of the Coroners Act 2006.

${ }^{19}$ I refer to paragraph numbers rather than page numbers when quoting coroners, as not all coroners' findings have page numbers, and it is a more precise pinpoint reference.
} 
This is because, as an Ideological State Apparatus, the purpose of the Coroners Court is to reproduce ruling class ideology. For Scraton and Chadwick, 'the intervention of the state's institutions - its very political management - reflects, transmits and reinforces the ideological construction of identities and reputations' $(1986,94)$. They argue that coroners' inquests draw on class, race and gender-based ideologies of the 'criminal' to justify custodial deaths. Razack, in the Canadian context, argues that settler-colonialism 'is the powerful context in inquests into the deaths of Aboriginal people in custody' (2011, 4-5). Inquests in Canada 'must establish anew how much beyond saving Aboriginal people actually are and how little can be done for them' (Razack 2011,2). It is in this sense that coroners' inquests are a site of conflict between the ideologies of settler-colonial capitalism and the bodies that are deemed disposable by that social system.

The conflict between the structures of settler-colonial capitalism and the bodies that are made disposable does not occur purely at an abstract level. There are, of course, actual people who experience custodial death. While coroners restrict the publication of the names of the deceased in four cases, in all other cases I have decided to use the real names of the people who died in New Zealand prisons. I use these peoples' real names precisely because they were real people, whose lives and deaths deserve consideration. The use of their names, I hope, humanises them in findings that otherwise do not do so. Where coroners prohibit me from using the real names of the deceased, I create a pseudonym, which I note in the relevant footnotes.

Returning to the state's investigative response to custodial death, as the Department of Corrections' Commissioner Lightfoot notes, all 'deaths in custody are reported to the New 
Zealand Police and are the subject of a Coronial Inquest and an investigation by an Inspector of Corrections' $(2016 \mathrm{~b}, 1)$. In other words, Corrections' account of the death comes from a 'Death in Custody Report', completed by an Inspector of Corrections. The Office of the Inspectorate is responsible for the investigation of complaints by prisoners, deaths in custody, and conducts regular reviews of prison practice. The outcomes of these investigations are reported to the Chief Executive of Corrections and are rarely made publicly available. ${ }^{20}$

There is a remarkable overlap between coroners' findings and Inspectors' reports. In the cases of Mark Te'o (Jamieson 2008), Alec Ali (Jamieson 2009a), and Duncan Frost (Jamieson 2011), the coroners' findings are effectively copied and pasted Inspectors' reports. In the overwhelming majority of cases, the coroner accepts the Inspector's report and repeats it, albeit in their own words. There are some important exceptions, where the coroner criticises the Inspector's report, but that is in the minority. I examine this relationship further in later chapters.

Like any text, coroners' findings contain multiple discourses which are contradictory. Although I interpret the purpose of the findings as to ideologically reproduce colonial capitalism and the prison, it is equally important to note that they do not have a totalising effect. Read together, the coroners' findings exceed this purpose. While on the one hand, attempting to justify the deaths either implicitly or explicitly, the findings also betray dehumanising practices and discursive contradictions that potentially threaten the existence of the prison.

\footnotetext{
${ }^{20} \mathrm{I}$ submitted an OIA request for a Death in Custody report produced by an Inspector, which was refused (Arbuckle 2017a).
} 


\section{Counting the Death of the Prisoner}

The Ideological State Apparatus of Coronial Services does not deal merely with words. The words the coroners use concern the material death of a person in custody. The detailing of these deaths in the coroners' findings enables a numerical counting of the deaths and their circumstances, where they are not censored by the coroner. This chapter counts deaths in New Zealand prisons. It provides some basic demographic data and quantitative analysis about the people who died in prison between July 1, 2007 and June 30, 2016.

Coronial Services distinguishes between natural and unnatural or non-natural deaths. It defines a death by natural causes as 'a death that is primarily caused by a disease or illness not directly influenced by external forces' (Coronial Services 2016a, n.p.). An unnatural death refers to all 'deaths that can't be described as death by natural causes', including 'accidents, homicide, suicide, violent death, falls, poisoning or overdoses (intentional and unintentional) and drowning' (Coronial Services 2016a, n.p.). The Department of Corrections also uses this distinction in its data collation. As a result, when it provides data under the Official Information Act (OIA) into deaths in custody, it refuses to divulge the number of suicides or self-inflicted deaths, referring only to natural and unnatural deaths. This is because the coroner ultimately decides the cause of death, not the Department of Corrections (Lightfoot 2016b).

Coronial Services provided me with 113 case files into deaths in prisons or Corrections custody. Of those, 1 involved the death of a prison officer, 3 were deaths while on home detention, 1 on compassionate release from prison, and 108 were people who died while a 
prisoner. As my focus is on deaths in prison custody, I will only refer to the 108 cases provided to me on that subject matter.

\section{Type of death}

Table 4 details the number and proportion of deaths of natural, unnatural, and unclear causes, as well as those censored under section 74 of the Coroners Act (referred to from here on as a ' 74 case'). Table 5 outlines the number and proportion of deaths that were self-inflicted. Tables 6 to 9 break down these tables further. Section 71 of the Coroners Act censors the publication of the particulars of $52.50 \%$ of unnatural deaths, as seen in Table 6 . Of the remaining 19 unnatural deaths which are publishable, $73.89 \%$ were suicides, $5.26 \%$ were murder, and $21.05 \%$ had an unclear cause, as seen in Table 8 . In Table $7,56.76 \%$ of selfinflicted death cases were censored under $\S 71$. There were 16 which were not $\S 71$ cases and of those cases, $87.50 \%$ were suicides and in $12.50 \%$ whether the death was a suicide or not was unclear (see Table 9).

Table 4: Unnatural or natural death

\begin{tabular}{|l|l|l|}
\hline Type of death & Count & \% of Total \\
\hline Natural & 66 & $61.11 \%$ \\
\hline Unnatural & 40 & $37.04 \%$ \\
\hline Unclear & 1 & $0.93 \%$ \\
\hline Section 74 & 1 & $0.93 \%$ \\
\hline Total & 108 & \\
\hline
\end{tabular}


Table 5: Self-inflicted or non-self-inflicted death

\begin{tabular}{|l|l|l|}
\hline Type of death & Count & \% of Total \\
\hline Self-inflicted & 37 & $34.26 \%$ \\
\hline Non-Self-Inflicted & 69 & $63.89 \%$ \\
\hline Unclear & 1 & $0.93 \%$ \\
\hline Section 74 & 1 & $0.93 \%$ \\
\hline Total & 108 & \\
\hline
\end{tabular}

Table 6: Unnatural deaths and section 71

\begin{tabular}{|l|l|l|}
\hline Section 71 Applies & Count & \% of Total \\
\hline Yes & 21 & $52.50 \%$ \\
\hline No & 19 & $47.50 \%$ \\
\hline Total & 40 & \\
\hline
\end{tabular}

Table 7: Self-inflicted deaths and section 71

\begin{tabular}{|l|l|l|}
\hline Section 71 Applies & Count & \% of Total \\
\hline Yes & 21 & $56.76 \%$ \\
\hline No & 16 & $43.24 \%$ \\
\hline Total & 37 & \\
\hline
\end{tabular}

Table 8: Unnatural death by type, excluding section 71

\begin{tabular}{|l|l|l|}
\hline Type of death & Count & \% of Total \\
\hline Suicide & 14 & $73.68 \%$ \\
\hline Murder & 1 & $5.26 \%$ \\
\hline Unclear & 4 & $21.05 \%$ \\
\hline Total & 19 & \\
\hline
\end{tabular}

Table 9: Self-inflicted death by type, excluding section 71

\begin{tabular}{|l|l|l|}
\hline Type of death & Count & \% of Total \\
\hline Suicide & 14 & $87.50 \%$ \\
\hline Unclear & 2 & $12.50 \%$ \\
\hline Total & 16 & \\
\hline
\end{tabular}

The data in Tables 4 to 9 is an analysis of the findings given to me by Coronial Services.

However, separate data I received from Coronial Services under the Official Information Act 
(Kelly 2017a; Skachill 2017) tell a slightly different story. According to Coronial Services, in the time-period for which I have data, July 1, 2007 to June 30, 2016, there were a total of 144 deaths in prison. That means there are 36 deaths for which I do not have a finding. ${ }^{21}$ Of those 144 deaths, $60.42 \%$ were from natural causes, $39.58 \%$ were unnatural and $35.42 \%$ were suicides.

As the Coronial Office could not provide me with data prior to July 1, 2007, I have an OIA response from the Department of Corrections that demonstrates that historically, the proportion of unnatural deaths was higher. Between July 1, 2000 and June 30, 2007, there were 90 deaths in prisons, $46.67 \%$ were from natural causes and $53.33 \%$ from unnatural causes. As is clear in Figure 1, the number of natural deaths has significantly increased in that period, while the number of unnatural deaths has fluctuated. Data in Figure 1 is a combination of data from the Coronial Office (Kelly 2017a) and the Department of Corrections (Lightfoot 2016b). Department of Corrections data did not include 2015/16 and the Coronial Office did not include 2000/01-2006/07. Further, according to the official Coronial data, the data from the Department of Corrections had 3 inaccuracies, where it either over- or understated the number of natural or unnatural deaths.

\footnotetext{
${ }^{21}$ As I note in chapter 2, this is because $22.22 \%$ of cases in that time-period have not yet been closed, and four cases have been closed between the last time I asked for cases from the coroner and the OIA data.
} 


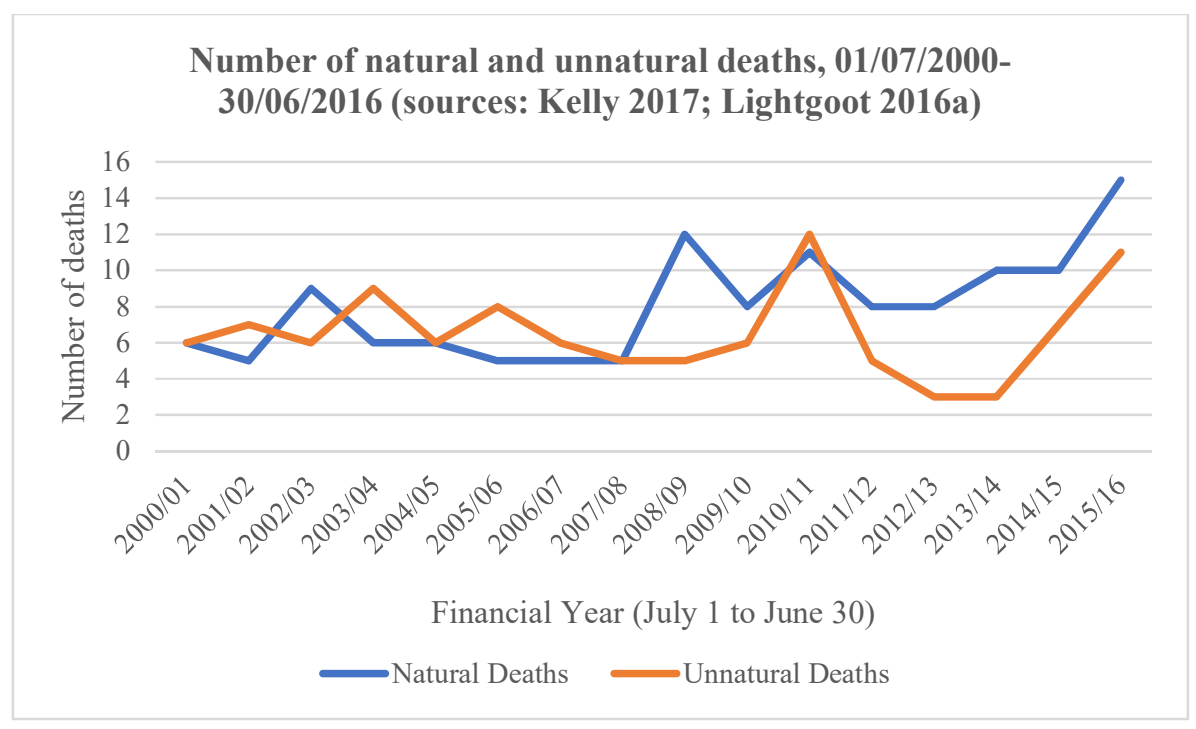

Figure 1: Number of natural and unnatural prison deaths

Figure 2 shows the number of deaths that a coroner has ruled to be a suicide between July 1 , 2007 and June 30, 2016. This data was provided to me under the Official Information Act (Skachill 2017). The average number of suicides in that period was 5.67 per year. Figure 3 displays the number of suicides per annum adjusted for the average daily prisoner population..$^{22}$ This data is expressed in suicides per 100,000 people. The number of suicides per 100,000 peaked in $2015 / 16$ at 119.66 per 100,000 . Overall in that time-period, the suicide rate was 66.59 per 100,000 . In the most recent reporting period, 2013, the suicide rate in the general New Zealand population was 11.0 per 100,000 (Ministry of Health 2016). That means prisoners took their own lives at a rate $505.36 \%$ greater than the general population.

\footnotetext{
${ }^{22}$ Although I requested the average daily prisoner population in an Official Information Act request, the Department of Corrections refused to provide me with the information. As a result, I found average daily population figures in Corrections' Annual Reports (Department of Corrections 2008, 2009, 2010, 2011, 2012, 2013, 2014, 2015, 2016a)
} 


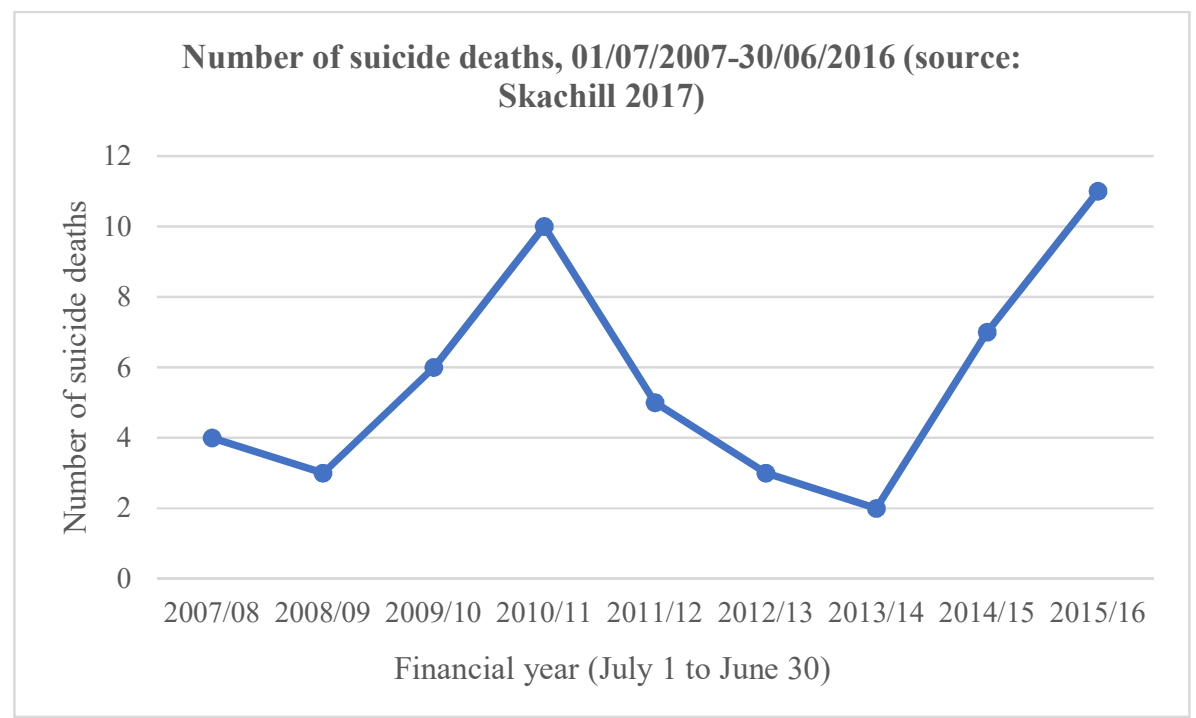

Figure 2: Number of prison suicide deaths (non-population-adjusted)

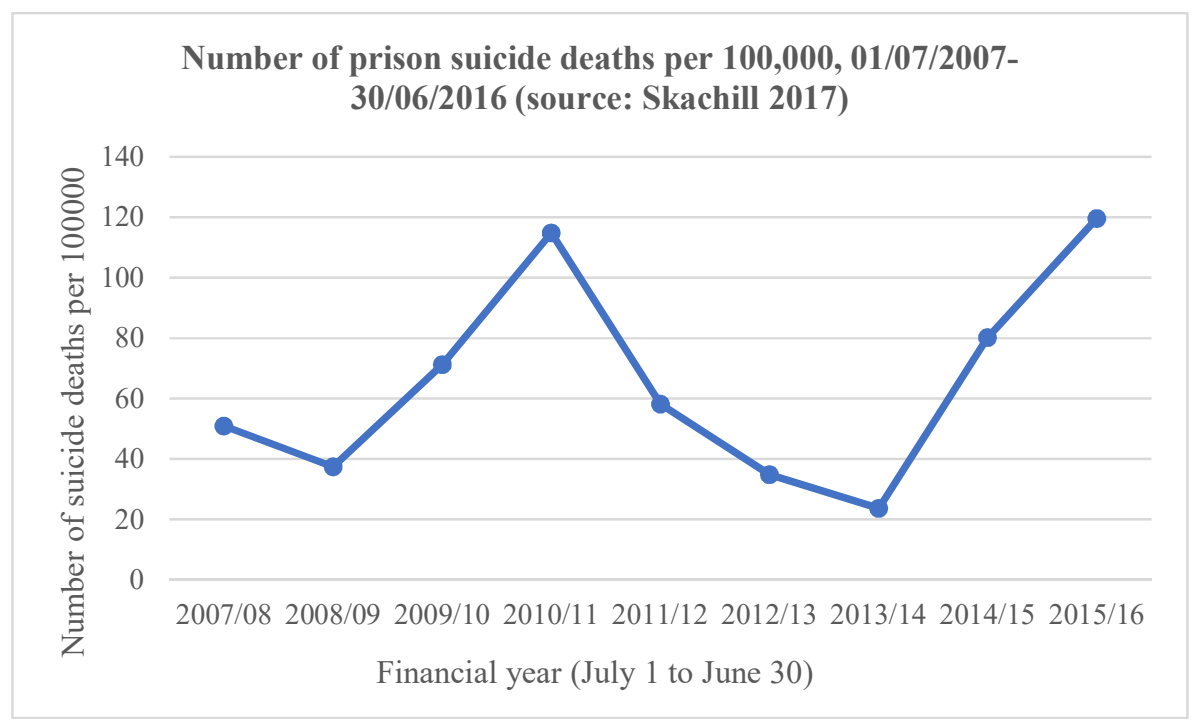

Figure 3: Number of prison suicide deaths per 100,000

'Sex'

Describing the gender of the deceased is difficult because of the way gender is constructed through prisoner management. I use the term 'people in men/women's prisons' because it is the most accurate way to talk about 'sex' in prisons with the data provided by the state. As 
noted by Dewing (2013) in her master's thesis research on transgender women in men's prisons in New Zealand, there are currently several women in men's prisons in New Zealand. ${ }^{23}$ According to OIA data released to me, as of September 30, 2016, there were 17 transgender people in New Zealand prisons (Lightfoot 2016a). Of course, the colonial state is unable to capture all the varieties and fluidities of gender, so for all cases referred to in this project, the coroner only refers to binary sexes. There may have been transgender people who have died in prison in New Zealand but, from the cases I have, there is no mention of anyone being transgender. That, of course, does not mean that none of the deceased were transgender.

Recognising those inherent flaws in the data I have relating to the 'sex' of custodial deaths, I critically adopt the state's language here for the sake of clarity and in recognition that most people are cisgender. People in women's prisons generally make up between 5-7\% of the total prison population at any given time, although the women's prison population is growing faster than the men's (Lamusse 2017b). According to snapshot population records between December 2009 and December 2016, people in women's prisons were on average $6.3 \%$ of the total prison population (Department of Corrections 2017b). ${ }^{24}$

Of the 108 cases of custodial death I received information about, 94.44\% $(n=102)$ occurred in men's prisons, $4.63 \%(n=5)$ occurred in women's prisons, and $0.93 \%(n=1)$ is a $\S 74$ case. As seen in Figure 4, 6.06\% $(n=4)$ of natural deaths were in women's prisons, while 93.94\% $(n=62)$ were in men's. $2.50 \%(n=1)$ of unnatural and $2.70 \%(n=1)$ of self-inflicted

\footnotetext{
${ }^{23}$ For an abolitionist response to the placement of transgender women in men's prisons, see No Pride in Prisons' Abolitionist Demands (Lamusse, Morgan, and Rākete 2016).

${ }^{24}$ I was unable to find data in the same form prior to 2009 so I could not provide a similar analysis for the entire time for which I have custodial death data.
} 
deaths were in women's prisons, while $97.50 \%(\mathrm{n}=39)$ and $97.30 \%(\mathrm{n}=38)$ respectively were in men's.

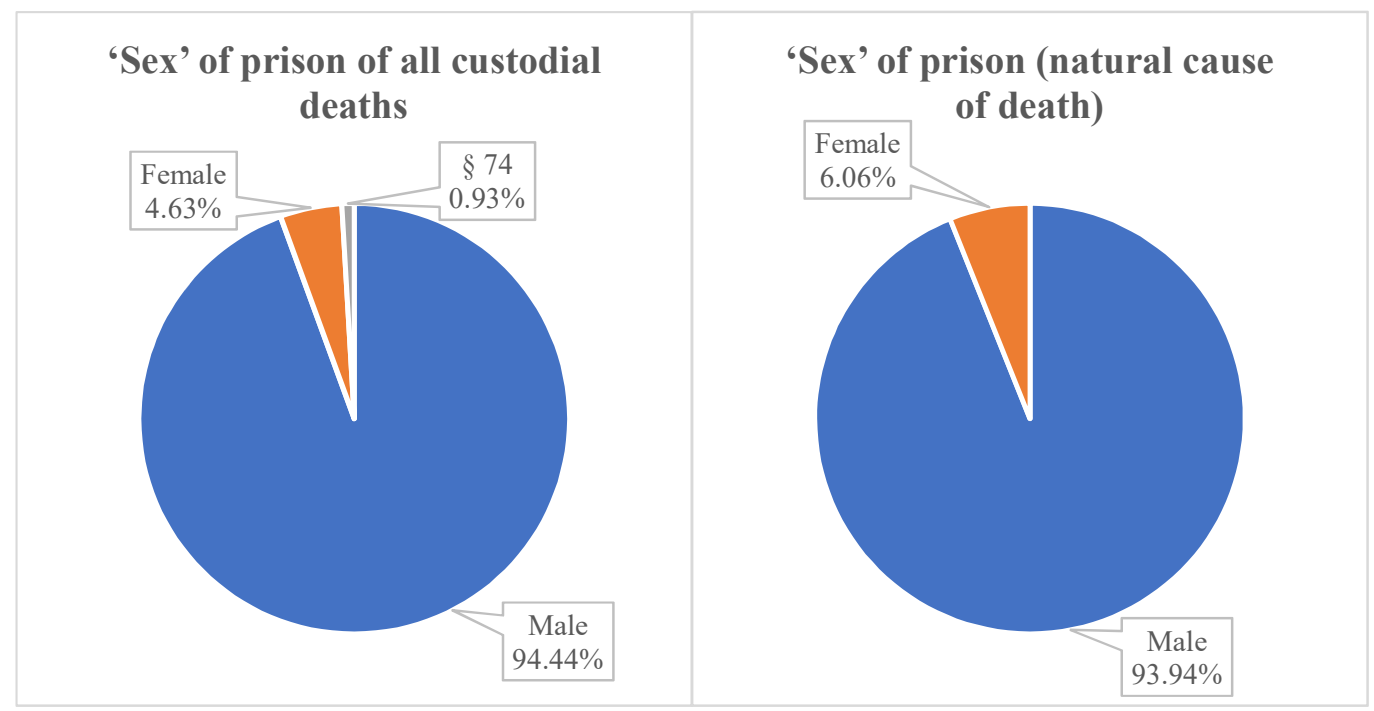

Figure 4: 'Sex' of prison of all prison deaths

Figure 5: 'Sex' of prison (natural cause of death)

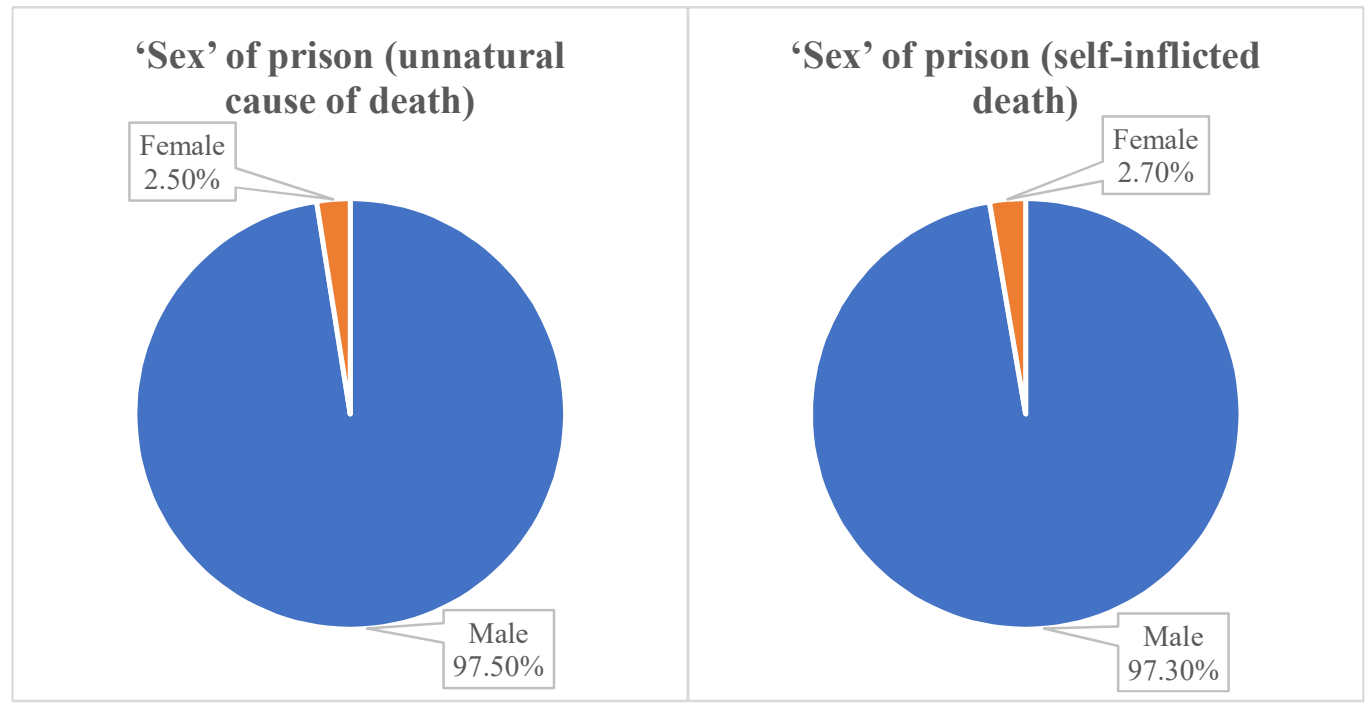

Figure 6: 'Sex' of prison (unnatural cause of death)

Figure 7: 'Sex' of prison (self-inflicted death)

However, data given to me by the journalist Donna-Lee Biddle ${ }^{25}$ suggests a different trend historically (Lightfoot 2016b). The data released to Biddle under the OIA contains unnatural

\footnotetext{
${ }^{25}$ Biddle received this information under the OIA. She spoke to me about a piece she was writing for the Waikato Times, based on this information. She did not use the information given to her from Corrections in the piece and it is clear that the editorial angle was substantially different from what she had intended. She gave me this data after her piece was released in the Waikato Times. You can read that article here: (Biddle 2016)
} 
deaths in custody broken down by year (January 1 to December 30 ) and prison, as well as year (January 1 to December 30) and ethnicity. The data is from January 1, 2000 until an unclear date in 2016, as the response does not state the clear cut-off date in 2016.

In the OIA response to Biddle's request, Corrections' National Commissioner Jeremy Lightfoot states that the 'name of the prison facility denotes the gender of the individual' deceased (Lightfoot 2016b, 3). In other words, the Commissioner takes for granted the necessary coherence of gender and prison placement. As noted above, I critically adopt the same criteria. Between 2000 and 2016, 7.06\% $(n=6)$ of unnatural custodial deaths were in women's prisons and $92.94 \%(n=79)$ were in men's. However, in the reporting period previous to the one for which I have cases (01/01/2000-31/12/2006), there were 33 unnatural deaths, $12.12 \%(n=4)$ of which were in women's prisons and $87.88 \%(n=29)$ in men's prisons.

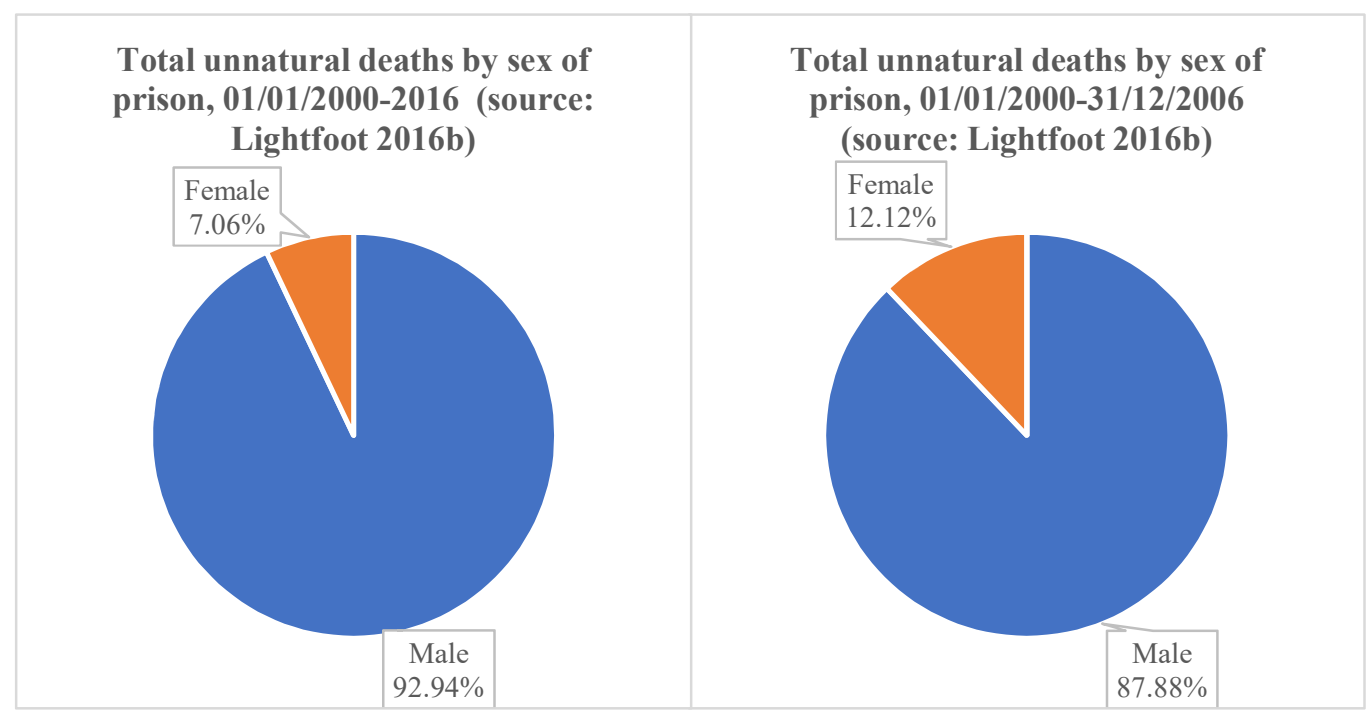

Figure 8: Total unnatural deaths by sex of prison, 2000- Figure 9: Total unnatural deaths by sex of prison, 20002016 2006

Given that women tend to make up between $5-7 \%$ of the prison population in New Zealand, between January 1, 2000 and December 12, 2006, people in women's prisons were overly 
represented in unnatural prison deaths, while they were underrepresented in the cases provided to me, being $2.50 \%$ of unnatural deaths in my data. Given the small number of deaths, and other limitations on the data, I will not make any further definitive statements as to the disproportionate number of either men or women who die in New Zealand prisons.

\section{Ethnicity}

The ethnicity of the deceased is rarely mentioned by coroners. This means I was unable to collect ethnicity data from the cases I analysed. However, in two OIA request responses from the Coronial Office, I was given the breakdown by ethnicity and gender of natural, unnatural, and suicide deaths. Figures 11-14 show that Pākehā are $45.14 \%$ of all prison deaths, $41.38 \%$ of natural deaths, $50.88 \%$ of unnatural deaths and $52.94 \%$ of suicide deaths. Māori make up $35.42 \%$ of all prison deaths, $36.78 \%$ of natural deaths, $33.33 \%$ of unnatural deaths and $31.37 \%$ of suicide deaths. This means there are proportionately more Pākehā prison deaths than Māori deaths compared to the overall prison population.

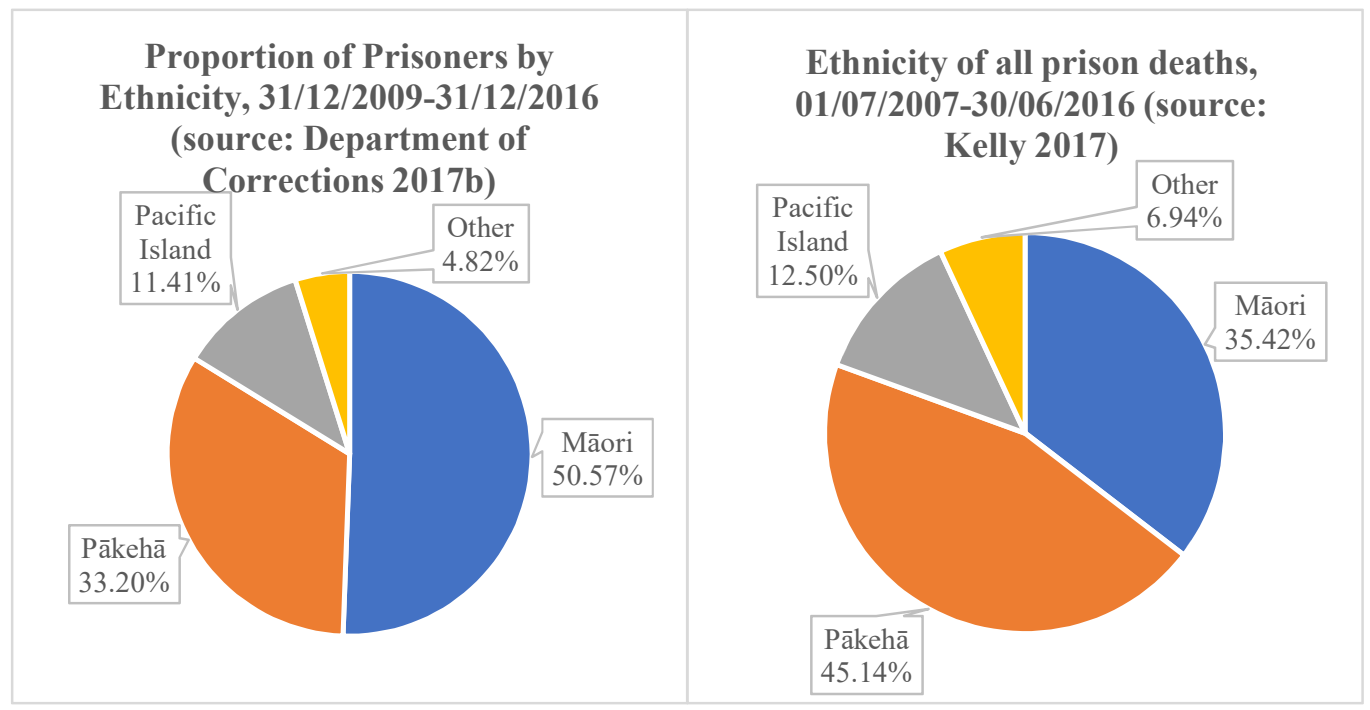

Figure 10: Proportion of prisoners by ethnicity

Figure 11: Ethnicity of all prison deaths 


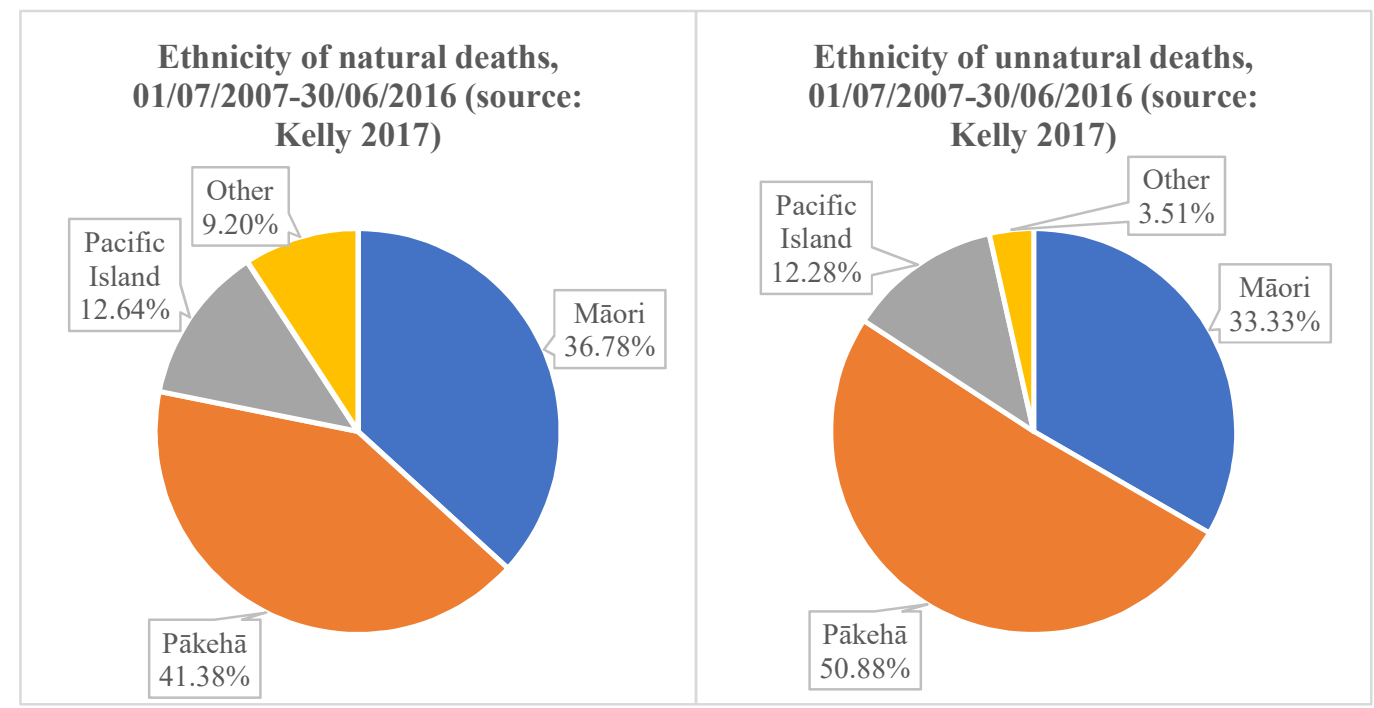

Figure 12: Ethnicity of natural deaths

Figure 13: Ethnicity of unnatural deaths

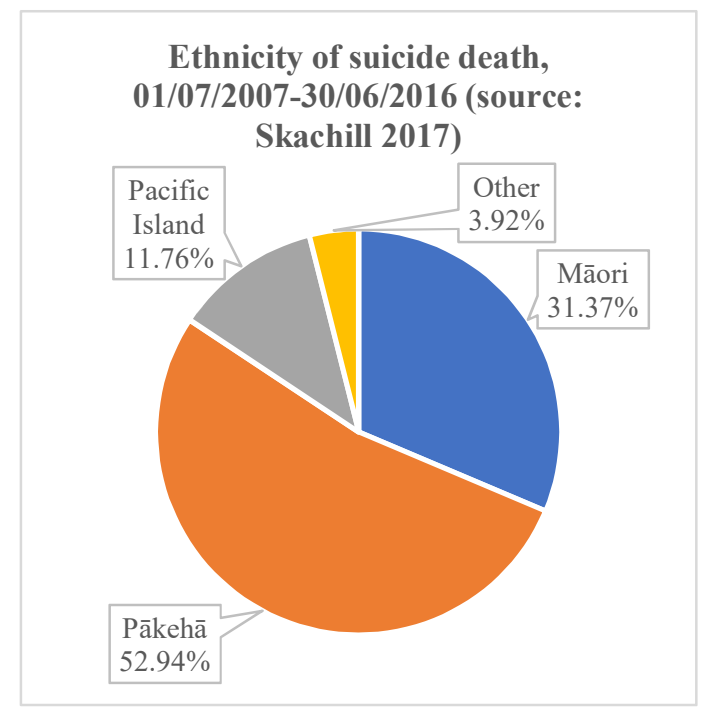

Figure 14: Ethnicity of suicide deaths

However, given Māori are over-represented in prison, compared to their proportion in the general population of New Zealand, Māori men are much more likely to die in prison than Pākehā men. ${ }^{26}$ Between July 1, 2007 and June 30, 2016, 2.31\% of suicide deaths for Māori men occurred in prison compared to $1.16 \%$ for non-Māori men. However, in 2015/16, which

${ }^{26}$ There is not enough data about women who have died in New Zealand prisons to make similar comparisons. 
had a spike in prison suicides, $6.02 \%$ of all suicides by Māori men occurred in prison. Prison suicides made up only $1.86 \%$ of suicides by non-Māori men. ${ }^{27}$

Because of the social system that funnels largely impoverished Māori into prisons, corresponding custodial deaths, while certainly not limited to Māori, remain a profound method of colonial violence. There is, however, a notable absence of any discussion of colonisation in the coroners' findings. As is elaborated below, the findings foreclose the possibility that a 'self-inflicted' death in prison could be anything but the fault of the deceased. Any discussion of the ongoing dispossession of Māori, and its relationship to Māori imprisonment, is similarly foreclosed.

\section{Age}

The median age of death for the cases I have is 48.77 years, compared to a median age of death of 78 for men and 83 for women in 2015 in the broader New Zealand population (MacPherson 2016). The median age of death from natural causes is 57 years, 31.96 years for unnatural deaths and 32.98 years for self-inflicted deaths. As seen in Table 10, 67.57\% of selfinflicted deaths were of someone under the age of 40 .

\footnotetext{
${ }^{27}$ I calculated this based on two OIA responses from the Coronial Office. First, the total number of suicides in New Zealand by fiscal year, broken down by ethnicity and sex (Kelly 2017b). Second, the total number of prison suicides by fiscal year, broken down by ethnicity and sex (Skachill 2017).
} 
Table 10: Age range for self-inflicted deaths

\begin{tabular}{|l|l|l|}
\hline Age range & Count & \% of Total \\
\hline $\mathbf{1 8}-\mathbf{3 0}$ & 18 & $48.65 \%$ \\
\hline $\mathbf{3 0 - 4 0}$ & 7 & $18.92 \%$ \\
\hline $\mathbf{4 0 - 5 0}$ & 8 & $21.62 \%$ \\
\hline $\mathbf{5 0 - 6 0}$ & 3 & $8.11 \%$ \\
\hline $\mathbf{6 0 - 7 0}$ & 0 & $0.00 \%$ \\
\hline $\mathbf{7 0}+$ & 1 & $2.70 \%$ \\
\hline Total & 37 & \\
\hline
\end{tabular}

The median age of death is, therefore, substantially younger among the prison population compared to the general population, as recognised by the Department of Corrections (Ong and Lynch 2016).

\section{Length of time in prison}

In 76 cases, it was clear from the context the number of days that the deceased was in prison prior to their death. I was able to find the number of days each person was in prison by calculating the number of days between their admission to prison and the date of their death. In 6 cases ( 5 natural, 1 unnatural), the coroners provide an unclear date of death because it occurred in the late evening or early morning over two dates. I used the latter date as date of death for consistency, although this decision did not affect the medians or the categorisation of days in prison in the tables below.

Of the 76 cases, the median number of days in prison before death was 501 . For natural deaths, the median number of days in prison prior to death was 720 days $(n=45), 33$ days for unnatural deaths $(n=30)$, and 51 days for self-inflicted deaths $(n=28)$. Tables 11 to 13 have a slightly different data set from the medians. In 4 cases ( 3 natural, 1 unnatural), the coroner 
provides an approximate number of days in prison by giving either the number of years or weeks the deceased was in prison prior to death. This data can be included in the tables below but not in the medians.

Table 11: Number of days in prison prior to death (all)

\begin{tabular}{|l|l|l|}
\hline Day range & Count & \% of Total \\
\hline $\mathbf{0 - 7}$ & 13 & $16.25 \%$ \\
\hline $\mathbf{7 - 1 4}$ & 5 & $6.25 \%$ \\
\hline $\mathbf{1 4 - 3 1}$ & 3 & $3.75 \%$ \\
\hline $\mathbf{3 1 - 1 0 0}$ & 8 & $10.00 \%$ \\
\hline $\mathbf{1 0 0 - 3 6 5}$ & 8 & $10.00 \%$ \\
\hline $\mathbf{3 6 5 - 7 3 0}$ & 12 & $15.00 \%$ \\
\hline $\mathbf{7 3 0}+$ & 31 & $38.75 \%$ \\
\hline Total & 80 & $16.25 \%$ \\
\hline
\end{tabular}

Table 12: Number of days in prison prior to death (natural death)

\begin{tabular}{|l|l|l|}
\hline Day range & Count & \% of Total \\
\hline $\mathbf{0 - 7}$ & 2 & $4.17 \%$ \\
\hline $\mathbf{7 - 1 4}$ & 4 & $8.33 \%$ \\
\hline $\mathbf{1 4 - 3 1}$ & 0 & $0.00 \%$ \\
\hline $\mathbf{3 1 - 1 0 0}$ & 3 & $6.25 \%$ \\
\hline $\mathbf{1 0 0 - 3 6 5}$ & 5 & $10.42 \%$ \\
\hline $\mathbf{3 6 5 - 7 3 0}$ & 10 & $20.83 \%$ \\
\hline $\mathbf{7 3 0}+$ & 24 & $50.00 \%$ \\
\hline Total & 48 & $100.00 \%$ \\
\hline
\end{tabular}

Table 13: Number of days in prison prior to death (self-inflicted death)

\begin{tabular}{|l|l|l|}
\hline Day range & Count & \% of Total \\
\hline $\mathbf{0 - 7}$ & 9 & $31.03 \%$ \\
\hline $\mathbf{7 - 1 4}$ & 1 & $3.45 \%$ \\
\hline $\mathbf{1 4 - 3 1}$ & 3 & $10.34 \%$ \\
\hline $\mathbf{3 1 - 1 0 0}$ & 5 & $17.24 \%$ \\
\hline $\mathbf{1 0 0 - 3 6 5}$ & 3 & $10.34 \%$ \\
\hline $\mathbf{3 6 5 - 7 3 0}$ & 2 & $6.90 \%$ \\
\hline $\mathbf{7 3 0}+$ & 6 & $20.69 \%$ \\
\hline Total & 29 & $100.00 \%$ \\
\hline
\end{tabular}


As Table 11 shows, the greatest proportion of deaths occur within the first 31 days $(26.25 \%)$ and after the first year $(53.75 \%)$. The reflects the fact that natural deaths tend to occur later in prison time, while self-inflicted deaths tend to occur earlier. As Table 13 demonstrates, $31.03 \%$ of self-inflicted deaths occur in the first week of imprisonment, and $44.83 \%$ within the first 31 days. Approximately a fifth of self-inflicted deaths occur after more than two years in prison. By contrast, only $12.5 \%$ of natural deaths occur within the first 31 days and $70.83 \%$ occur after the first year.

\section{Prisoner Type}

The differences in length of time in prison prior to death are also reflected in the type of prisoner, remand or sentenced. If someone is sentenced, it means that they have been found guilty of an offence and have been sentenced to imprisonment. If someone is on remand, they have either been charged with something but their culpability has not been established by a court (remand-accused), or they have been found guilty of an offence and are awaiting sentencing (remand-awaiting-sentence). A prisoner's sentenced or remand status can play a significant role in a person's experience of incarceration. Multiple reports by the Office of the Ombudsman have demonstrated that prisoners on remand generally have less access to purposeful activities and are more susceptible to violence (Boshier 2016a, 2016b, 2017b, 2017c).

Of cases where the prisoner status is stated $(n=95), 68.42 \%(n=65)$ of prisoners were sentenced, and $31.58 \%(\mathrm{n}=30)$ were on remand. According to my calculations based on snapshot population records between December 2009 and December 2016, on average 77.68\% 
of the prison population was sentenced and $22.32 \%$ was on remand. ${ }^{28}$ From this data, sentenced prisoners are more likely to die of natural causes $(87.27 \%)$ than remand prisoners (12.73\%). By contrast, self-inflicted deaths were substantially more likely to have occurred while on remand $(58.33 \%)$ than for sentenced prisoners $(41.67 \%)$.

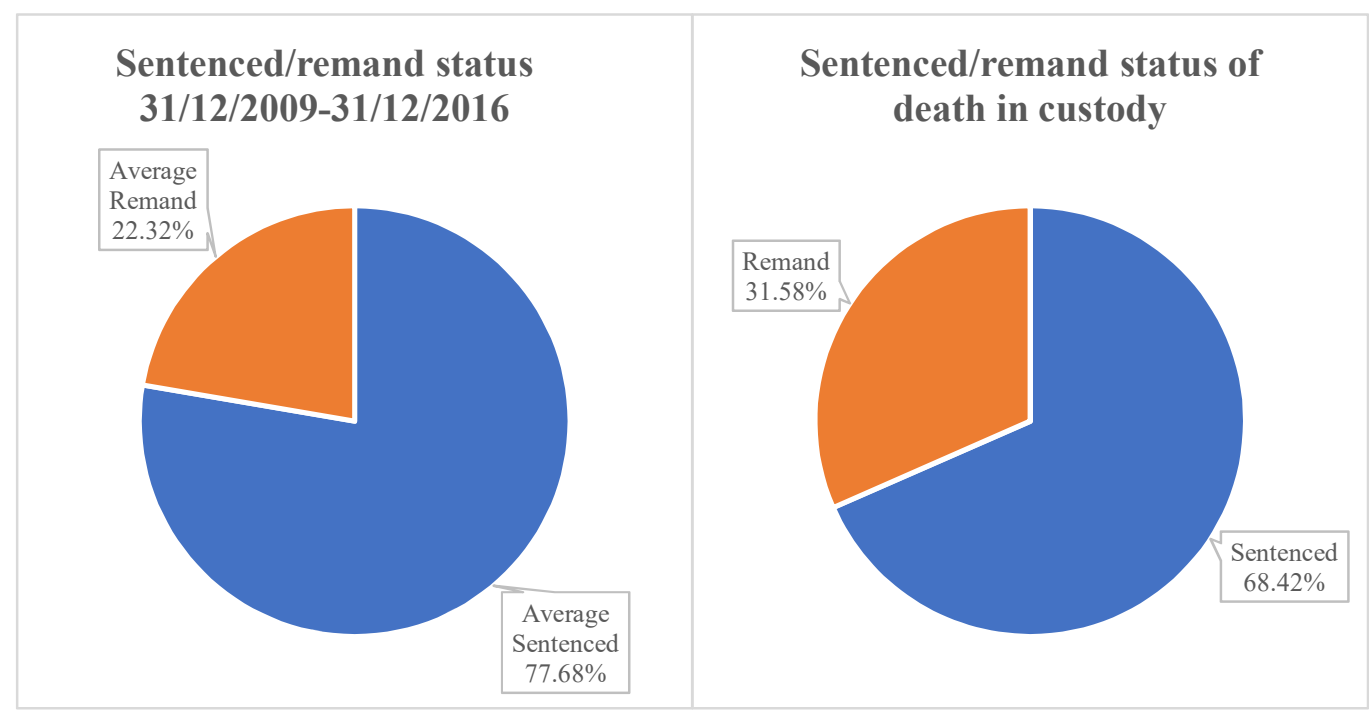

Figure 15: Sentenced/remand status

Figure 16: Sentenced/remand status of all deaths in prison

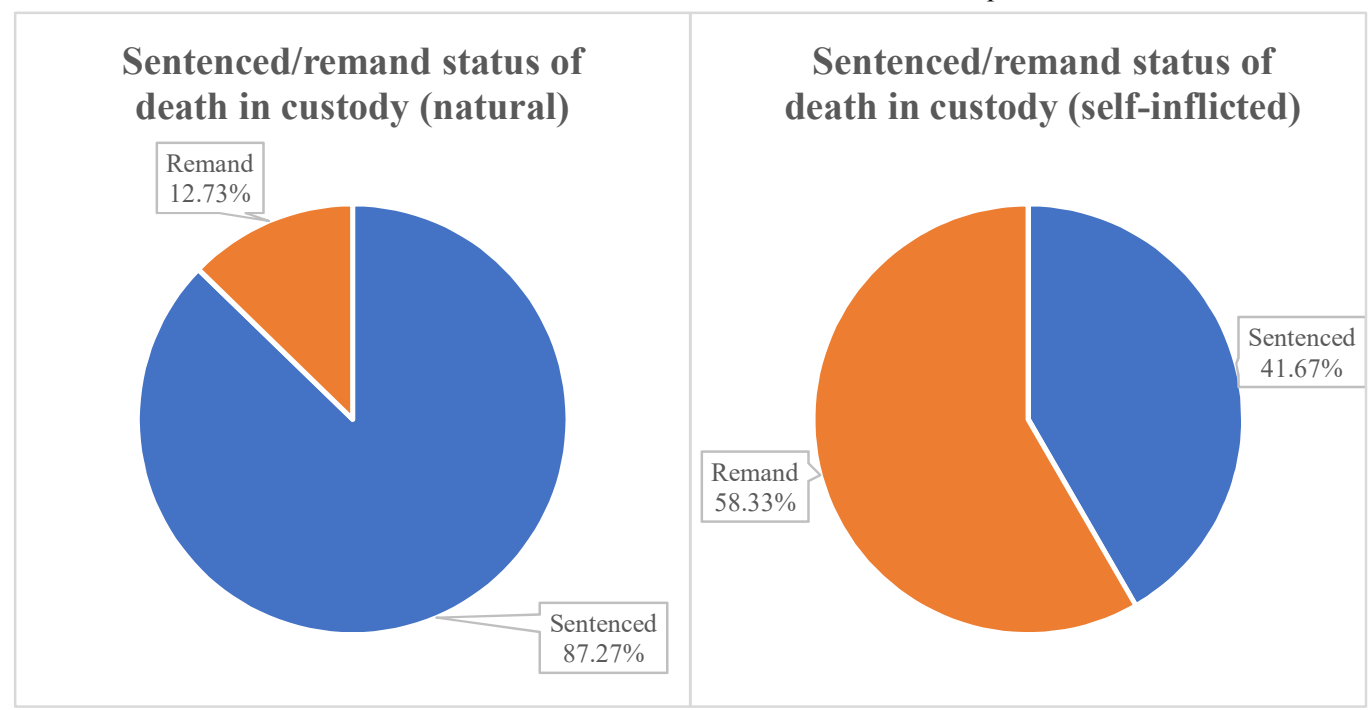

Figure 17: Sentenced/remand status of death in prison (natural)

Figure 18: Sentenced/remand status of death in prison (self-inflicted)

${ }^{28}$ There has, however, been a substantial increase in the number of prisoners held on remand following the Bail Amendment Act 2013 coming into effect. For an analysis of the impact of the Bail Amendment Act on the remand prisoner population, see here: (Lamusse 2017b) 
Where the death was self-inflicted, I also collected data on whether it was the deceased's first time in prison. Of those self-inflicted deaths, it was the first time in prison for $8.11 \%$ of deceased $(n=3)$, it was not the first time for $27.03 \%(n=10)$, it was unknown in $8.11 \%(n=$ $3)$, and this particular was censored in $56.76 \%$ of cases $(n=21)$.

\section{On counting}

The quantitative analysis I have included thus far provides a snapshot of the population affected by prison death in New Zealand. I weave additional quantitative analysis into the subsequent chapters, providing some further context for my materialist discourse analysis. In this chapter, the numbers I provide are simply an attempt to numerically count the death of prisoners in New Zealand. As Butler (2010) argues, however, to numerically count a death does not mean that that life counted. For Razack, who counts custodial deaths of indigenous people in Canada, the 'overemphasis on the numbers can indicate a reluctance to confront what lies beneath them' $(2015,193)$. A numerical accounting does not ultimately account for whether that life mattered, or whether the circumstances surrounding the death mean that the life that was once living was a life worthy of living. In the following chapters, I provide an account of those who do not count. 


\section{Vilification, Abjection, Dehumanisation}

The prison in Aotearoa emerges within the normative regimes of capitalism and ongoing settler colonisation. The social conditions of settler-colonial capitalism are materially reproduced through normative practices, which in turn reproduce normative ideals. The subject is required to repeatedly act in ways that ascribe to these normative ideals. However, 'that repetition establishes a domain of risk, for if one fails to reinstate the norm "in the right way," one becomes subject to further sanction, one feels the prevailing conditions of existence threatened' (Butler 1997b, 28-29).

This 'sanction' is, for some, imprisonment. Norms require exclusion and repudiation to secure the borders of what it means to be a subject. In order for subjects to be recognisable as subjects, there must be a 'simultaneous production of a domain of abject beings' (Butler 2011, xiii). For Butler, abjection 'literally means to cast off, away, or out' (2011, 186 n. 2). Abject beings are those that are cast out into prisons, refugee camps, and slums. Many people who find themselves in prison come from abject zones of wider society, living in social conditions with poor health, education and life-expectancy, as well as being disproportionately likely to be victimised. These abject beings, by virtue of their abjection, are ready for their further dehumanisation through criminalisation and incarceration.

In such a way, normative regimes establish not only what it means to be human according to a normative standard, but also unlivable zones which are inhabited by abject beings. Norms create a paradox in which the category of human presupposes the category of the inhuman human, the person who cannot be understood as fully human. These inhuman human beings 
are the constitutive outside of the normative construction of the human. As the human is constructed through this process of abjection, it is simultaneously defined in relation to the not-human, being its 'founding repudiation' (Butler 2011, xiii). The prison is a site for the collection of many of these abject beings, the majority of whom are indigenous, who have been cast out and repudiated for their failure to adhere to normative standards.

However, the prison is not a monolith that has existed and will exist for all time. As with all social structures, it requires constant reproduction through material practice. In part, it must continually reproduce abject beings. As I outline in what follows, coroners, as components of an Ideological State Apparatus, both detail material practices that reproduce the abjection of incarcerated people, as well as reify their necessary abjection.

\section{Vilification}

The vilification of the deceased in many of the coroners' findings constitutes part of the ideological interpellation of the deceased as bad, a 'criminal', who is necessarily-imprisoned. This occurs, in part, when the coroners provide background information about the deceased. In cases where the coroner provides this context about the deceased's life, they often discuss the deceased's life history and criminal history. This can sometimes involve a discussion of the fact that the deceased was in state custody from a young age. The coroner in the case of Barry Ryder, for example, notes that Barry had been in state custody almost his entire life, as he was taken into state care at age five and was in and out of prison for most of his life.

Coroner Devonport states that 
As to Mr Ryder's childhood background, because I think it is important, Mr Ryder was reported to have been in 38 different homes or institutions during his life. In 1969, at the age of seven months, Mr Ryder was placed in preventive supervision for a year but extended annually thereafter due to his living in a detrimental environment, a poor standard of living, hygiene and care being cited. By age four $\mathrm{Mr}$ Ryder was committing burglary (Devonport 2012b, para. 11)

Several coroners note that those who died of self-inflicted death were abused as children in state custody, including Taffy Hotene (na Nagara 2011c) and Barry Ryder (Devonport 2012b).

However, this acknowledgement of what could be a difficult childhood can quickly turn into the vilification of the deceased. In the case of Barry Ryder, Coroner Devonport states that 'At age 10 Mr Ryder's behaviour was noted as very disturbed, violent and using weapons, often hurting animals and even attempting sexual intercourse with a dog belonging to his foster parents' (2012b, para. 13). In the case of Bradley Twidle, Coroner Devonport points to the deceased as being troubled from childhood, stating that Bradley

engaged in aggressive, antisocial behaviour from a very early age, which resulted in suspension from school and a good deal of violent behaviour at home... He also reports having been a victim of a sexual assault and essentially his life course continued to be troubled by offending, poor anger control and drug abuse, and he achieved only episodic unskilled employment (Devonport 2015a, para. 5) 
Implicit in Devonport's statement is that Bradley was a bad egg from the start. He was broken and unable to regularly fulfil the most basic function of the proletariat in capitalism: employment. This, in effect, amounts to a vilification of the deceased, constructing him as an at least troubled, if not bad, person.

However, it is important to note that certain parts of this background information, such as histories of abuse and sexual assault, could be used to humanise or make the deceased appear more sympathetic. Instead, coroners use this information to explain their bad behaviour or to construct the image of the deceased as broken.

The vilification of the deceased through background information is complemented by sometimes extensive discussion of the deceased's (alleged) offending. From my quantitative analysis of coroners' discussion of it, coroners mention the nature of the deceased's (alleged) offending in $62.04 \%(n=67)$ of cases, did not in $37.04 \%(n=40)$ of cases and $0.93 \%$ was a $\S 74$ case $(n=1)$.

A typical discussion of the deceased's (alleged) offending occurs in the case of Dallas Pettigrew. In that case, Coroner Devonport stresses that 'Mr Pettigrew was well known to the Court and prison system, having amassed a total of 117 convictions between 1987 and the date of his death. The offences included burglary, unlawful interference with motor vehicles, unlawfully in enclosed yards, trespass, common assault, cannabis related offences, breach of bail and breach of community service' (2010a, para. 3). Similarly, in the case of Brian Scott, Coroner Smith notes that 'Mr Scott had been convicted in the Dunedin District Court on 26 
May 2011 of multiple charges stemming from the 1970s and relating to sexual offending on children (male and female) all under the age of 16' (2014, para. 3).

In contrast, some coroners specifically reject the temptation to detail the deceased's offending. Coroner Scott states, in the case of William Bayne, that William 'had been sentenced on the 23rd of May 2014 in the Wanganui District Court - the offence in respect of which the sentence was imposed is not relevant' (2016c, para. 1). However, in the case of Donald Gisborne, Coroner Scott says that 'the nature and extent of his offending, which I won't canvas here... was serious and family-related... Incidentally I don't restrict the publication of the reason for his imprisonment, I just don't mention it in this decision, it's not relevant' (2012b, para. 4). In this case, although Coroner Scott does not want to 'canvas' the nature of Donald's offending, he still mentions that it was 'serious and family-related', effectively stating it while recognising it as irrelevant information.

Although it may not have been the intention of the coroners to vilify the deceased by noting their (alleged) offending, vilification acts as a way to justify their imprisonment. It is a reminder that, although this person may have died in prison, they were in prison because they had been accused of or found guilty of engaging in activities that the state deemed harmful enough to warrant imprisonment.

As noted, the purpose of the coroners, under section 4(2) of the Coroners Act 2006, is to 'establish, so far as possible — (i) that a person has died; and (ii) the person's identity; and (iii) when and where the person died; and (iv) the causes of the death; and (v) the 
circumstances of the death'. There is no reason, given this purpose, for coroners to provide extensive detail about a deceased's alleged offending. While in some cases the detailing of criminal history may be an attempt to understand the deceased and the circumstances leading up to their death, statements of criminal history are not isolated from the ideological context in which they are made.

For Butler, 'no term or statement can function performatively without the accumulating and dissimulating historicity of force' $(2011,172)$. In other words, a statement gains meaning and power by drawing on a history of utterances of similar statements. In this way, statements about a deceased's alleged offending draw on a history of statements that exceed the statement itself. This history of statements includes other coroners' findings, media crime-reporting, party-political and government rhetoric, as well as other statements which produce a dominant ideology in which the 'criminal' is demonised.

Pratt (2007) argues that New Zealand's political response to social harm is defined by its ‘penal populism'. Penal populism

feeds on expressions of anger, disenchantment and disillusionment with the criminal justice establishment. It holds this responsible for what seems to have been the insidious inversion of commonsensical priorities: protecting the well-being and security of law-abiding "ordinary people", punishing those whose crimes jeopardize this (Pratt 2007, 12). 
Penal populist discourse draws marked distinctions between 'ordinary people', who are lawabiding and worthy of protection, and 'criminals' who undermine society and are worthy of punishment. This is exemplified by commentary from Cameron Slater from the reactionary WhaleOil Blog. In response to New Zealand's rapidly increasing prison muster, Slater comments 'Excellent. More bad scumbags in prison sounds great to me. Instead of it being trumpeted as a failure, it should be seen as a success that the public is protected from these bastards' (2016, n.p.).

In this way, when coroners provide background information about a deceased's (alleged) offending history, they draw on discourses of penal populism that presuppose that people in prison are 'bastards' and 'scumbags' who threaten the safety of the public. Importantly, however, coroners do not vilify the deceased to the same degree in all types of deaths. Although coroners mention the deceased's offending in the majority of cases, as demonstrated in Figures 19 and 20, coroners mention the nature of the deceased's (alleged) offending substantially more often in self-inflicted deaths (81.08\%) than natural deaths $(51.52 \%)$.

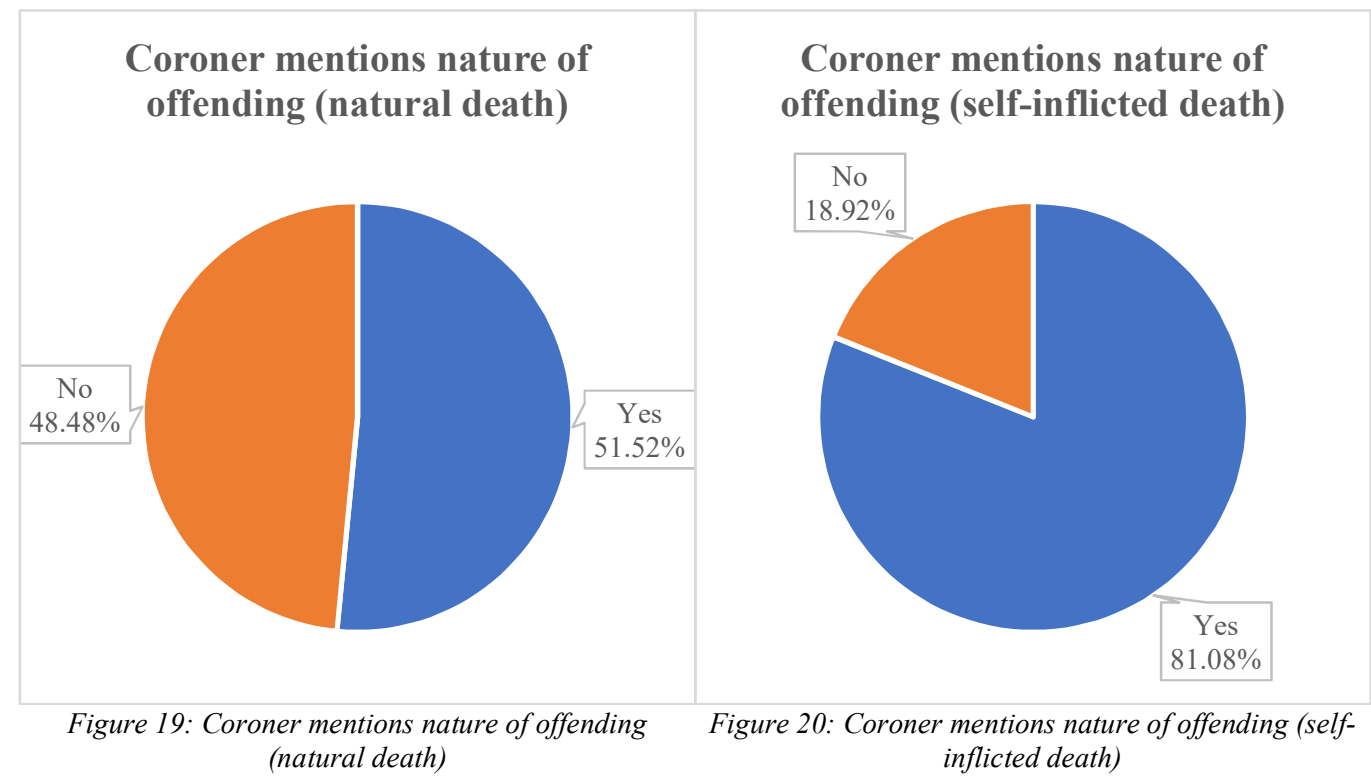


This betrays the purpose of 'background information' that coroners provide. The purpose of this 'background information' exceeds the legislative purpose of the coroner. The purpose is to exonerate the state for its role in the death of the incarcerated person who took their own life. Where a preventable death, such as a self-inflicted death, rightfully requires the state to consider the conditions in which that person was living prior to their death, the vilification of the deceased forecloses the need for such consideration. Vilification re-establishes that the deceased was a bad person, worthy of abjection and incarceration. In drawing on penal populist discourses, the vilification reconstructs the deceased as a person who was less than human. This coronial dehumanisation, especially in cases of preventable death, reassures the state that the loss of the prisoner was not the loss of a worthy life. In this vein, the reactionary lawyer Stephen Franks begs in a blog post, 'More deaths in prison please' (2011, n.p.).

Although prisons and prisoners are the constitutive outside of and abjected from normative regimes of power, this does not mean that they exist outside of power and politics. Butler argues that the 'jettisoned life' is 'saturated in power, though not with modes of entitlement or obligation. Indeed, the jettisoned life can be juridically saturated without for that reason having rights, and this pertains to prisoners as well as to those who live under occupation' (Butler and Spivak 2007, 32). Despite being abject and having no or limited rights, those bodies that are not considered human, are still subject to norms. Within the localised settings of prisons, there are normative practices that are enacted upon and by the bodies of prisoners (Butler 1997b). In what follows, I argue that these localised norms are norms of dehumanisation. Because normative regimes outside the prison depend on the abjection of prisoners, the prison becomes a site for the reproduction of norms of dehumanisation. 


\section{Presupposition of dehumanisation}

For norms to continue to exist, they must be constantly reproduced through regularised practice. The wider societal normative environment condemns and expels to the prison a small subset of bodies that have been found to have breached criminal laws and norms of behaviour. The prison becomes an abject zone at the margin of society. As its constitutive outside, it haunts normative society, threatening repudiation for non-normative practice.

The bodies thrown into prisons are interpellated as inhuman by virtue of being condemned. This interpellation requires reiteration. The norms that deny humanity to prisoners must be constantly reproduced through regularised practice within prisons. It is through these sometimes-small-scale practices that humiliate and dehumanise incarcerated people that the wider societal norms that condemn prisoners to inhumanity are validated.

Coroners reify this dehumanisation not only through the vilification of the deceased, but also through the uncritical reproduction of Corrections' policy as natural and inevitable. An example of this is the denial of the full status and meaning of 'worker' to incarcerated workers. Within the logics of capitalism, for those who do not own the means of production, their social meaning is largely determined by their ability to sell their labour-power commodity (Marx 1976a). Prior to its July 2016 amendment, section 71(2)(a) of the Coroners Act 2006, which limits one's ability to publish 'particulars' about suicide deaths, specifically allowed for the publication 'the name, address, and occupation of the person concerned'. The 'Certificate of 
Findings', which is a summary of the findings and circumstances of the death, always contains a place to name the deceased's occupation.

As seen in Table 14, although the coroner did not name the occupation of the prisoner in $6.48 \%$ of cases $(n=7)$, in $85.19 \%$ of cases $(n=92)$ the deceased's occupation was categorised as either a prisoner or unemployed.

Table 14: Occupation of deceased according to coroners' certificate of findings

\begin{tabular}{|l|l|l|}
\hline Occupation & Count & Percentage \\
\hline Not applicable & 1 & $0.93 \%$ \\
\hline Not applicable (sentenced prisoner) & 2 & $1.85 \%$ \\
\hline Prisoner & 76 & $70.37 \%$ \\
\hline Retired & 2 & $1.85 \%$ \\
\hline § 74 & 1 & $0.93 \%$ \\
\hline Sickness Beneficiary & 2 & $1.85 \%$ \\
\hline Unemployed & 15 & $13.89 \%$ \\
\hline Unemployed/Prisoner & 1 & $0.93 \%$ \\
\hline Unknown & 1 & $0.93 \%$ \\
\hline Unstated & 7 & $6.48 \%$ \\
\hline
\end{tabular}

In no case was an occupation that included paid wage labour provided. However, many prisoners do engage in wage labour and have occupations including chef, cleaner, painter, construction worker, agricultural worker, forestry worker, and groundskeeper (Department of Corrections 2001). Some coroners note the nature of the deceased's work in prison prior to their death. For example, at Whanganui Prison, Taffy Hotene was a concrete factory worker (na Nagara 2011c) and Rufus Marsh was a groundskeeper (na Nagara 2011b). However, in both cases the coroner categorises them as having the occupation of 'prisoner'. 
This reflects a policy framework that denies incarcerated workers the rights, although limited, enjoyed by non-incarcerated workers. Corrections' 'Inmate Employment Policy' states that 'Inmates are not employees of the Department of Corrections and are therefore not subject to the same wage rates, rights and remedies as private sector workers' $(2001,5) .{ }^{29}$ As a result, incarcerated workers are paid between ' $\$ 0.00$ per hour to $\$ 1.00$ per hour' (9). Coroners never question this policy. Although it was not considered by the coroner to be a factor in Tipene Pomare's death, it is important to note that in the lead up to his death, Tipene had to forfeit $\$ 60$ of earnings due to a misconduct process (Evans 2015). While that may not appear to be a large amount of money to a coroner, incarcerated workers in New Zealand receive slave wages. For an incarcerated worker earning the highest level of 'incentive payment', \$1 per hour, a $\$ 60$ fine amounts to 60 hours of unpaid labour. The denial of even the right to be employees casts incarcerated workers down into an inhuman category of slave. ${ }^{30}$

A further issue of dehumanisation that is passed over by multiple coroners is the fact that prior to taking their lives, several prisoners had recently spent time in the Kia Marama programme at Rolleston Prison. The Kia Marama programme is a psychological 'treatment' for child sex offenders with the purpose of reducing reoffending. However, elements of the 'treatment' are undeniably cruel and humiliating. According to a Corrections evaluation of Kia Marama, a core component of the 'treatment' is 'arousal conditioning'. This involves 'Directed masturbation, in which the man is encouraged to become aroused by any means but once aroused, to masturbate to images of consenting adults' (Bakker et al. 2000, 8). While not enough is yet published about Kia Marama, the idea of being directed to masturbate and

\footnotetext{
${ }^{29}$ In an Official Information Act request, the Department of Corrections indicates that the 2001 Inmate Employment Policy is the most up to date policy on work in prisons (Lightfoot 2016d).

${ }^{30}$ For a full discussion of penal slavery in New Zealand, see No Pride in Prisons' Abolitionist Demands (Lamusse, Morgan, and Rākete 2016, 83-88)
} 
orgasm by a person in a position of authority could certainly be sexually humiliating and demeaning for the subject.

In the cases of Bradley Twidle and Michael Maxwell, both deceased took their lives shortly after being ejected from the Kia Marama programme. Both people were recognised as being difficult to manage while in the Kia Marama unit. While in that unit, Bradley assaulted another prisoner. According to the Unit Manager, Michael's 'behaviour while at Kia Marama was in his opinion the worst of approximately 500 inmates during his time as Unit Manager, which role he commenced in 2000, and that Mr Maxwell's behaviour was "toxic" for the treatment of the other prisoners while he was in the Unit' (Devonport 2011, para. 41). The coroner in both cases, Coroner Devonport $(2011,2015 \mathrm{a})$, highlights the behaviour of the deceased in the unit to establish that both men were difficult to manage. Although there is insufficient evidence to draw further conclusions, the fact that both men recently endured the Kia Marama programme, had both been sexually assaulted in their lifetimes, and had been disruptive while in the programme may suggest that the programme itself was causing the men considerable psychological distress.

\section{Isolation and punishment}

A core dehumanising component of the disciplinary regime of New Zealand prisons is cell confinement and isolation. From the cases I have that are not censored by section 71 , at their time of death, $12.50 \%$ of self-inflicted deaths $(n=2)$ occurred while on Directed Segregation. Directed Segregation, although practiced in different ways from prison to prison, amounts to

a dehumanising condition of confinement. Recent investigations by the Office of the 
Ombudsman find that 'Most prisoners placed on directed segregation were not receiving their daily minimum entitlement of one hour in the open air at Rimutaka, Mt Eden and Auckland' prisons and that the standard of Directed Segregation accommodation in Auckland Prison particularly 'could be considered cruel and inhuman' (Office of the Ombudsman 2014, 21).

Directed Segregation can occur for five reasons under the Corrections Act 2004. Prisoners can be placed in Directed Segregation for the 'security or good order of the prison', ${ }^{31}$ 'the safety of another prisoner or another person', ${ }^{32}$ 'the safety of the prisoner', ${ }^{33}$ or for the prisoner's 'physical' or 'mental health'. ${ }^{34}$ Importantly, as Commissioner Lightfoot writes in an OIA response, 'Directed segregation is not a means of discipline' (Lightfoot 2016c, 3).

Tipene Dawson was one of the 2 uncensored self-inflicted deaths that occurred in Directed Segregation. Tipene's case demonstrates that Directed Segregation can certainly amount to cruel and inhuman treatment. Although Directed Segregation was not part of Tipene's official punishment, it was unofficially used to discipline him as it occurred immediately 'after having been dealt with through the Department of Corrections' internal misconduct process' for damaging prison property (Evans 2015, para. 3). He was segregated under section 58(1)(a) of the Corrections Act, for the 'security or good order of the prison'.

\footnotetext{
$31 \S 58(1)(\mathrm{a})$

$32 \S 58(1)(b)$

$33 \S 59(1)(\mathrm{b})$

${ }^{34} \S 60(1)$
} 
As a condition of his confinement, Tipene was denied the ability to associate with other prisoners for the first ten days in Directed Segregation. This means his only interaction with other people for ten days was with his imprisoners. Corrections Officer 'Brosnahan was asked to explain the connection between [Tipene's] act of destroying or damaging prison property and the prohibition on his association with other prisoners. Mr Brosnahan said that, in hindsight, [Tipene] could have been started off earlier in associating with other prisoners' (Evans 2015, para. 20). In retrospect, Officer Brosnahan noted that the non-association condition was 'possibly overkill', although 'the normal course is to deny association during the first three days of Directed Segregation' (Evans 2015, para. 20). Coroner Evans also comments that prisoners on Directed Segregation 'under section 58(1)(a) and (b) of the Act appear more often than not to be subject to an order which denies their ability to associate with other prisoners of a similar category from the onset and for the duration of their segregation' (2015, para. 41).

After thirteen days on Directed Segregation, and one day before he was due to be transferred to a mainstream unit, Tipene took his own life. Residential Manager Damian Wanoa gave evidence that Tipene's segregation status was reviewed on the third, fifth and tenth days of his segregation. Coroner Evans, however, 'comments that it does not appear any record was made of such reviews' (2015, para. 29). He further notes that the 'Management Unit PCO stated that few prisoners are relocated back to mainstream prior to the conclusion of initial 14-day segregation orders' (2015, para. 41). ${ }^{35}$ Although it is unclear from the findings exactly

\footnotetext{
${ }^{35}$ As a response to Coroner Evans' criticism, the Department of Corrections ensured the coroner that they were undertaking a review of the use of Directed Segregation. The review was to also 'establish whether the practice of full 14 days segregation for prisoners on initial segregation is widespread nationally' (Burns quoted in Evans 2015, para. 35). However, in response to my OIA about the use of 14 day segregation, Corrections says that the 'review did not establish whether these practices were widespread' (Lightfoot 2017, 2).
} 
how many hours per day Tipene was confined in his cell, it is implied in the findings that Tipene may have spent up to 24 hours per day inside and certainly was isolated from other prisoners for the first 10 days. Given that, in a report into prisons in 2013/14, the Ombudsman (2014) finds Directed Segregation prisoners at Rimutaka, where Tipene was confined, were denied their minimum one hour of fresh air daily, it appears that Tipene may have endured those conditions of total confinement prior to his death in 2014.

As noted above, segregation and isolation are legally sanctioned components of prison management in New Zealand. In her study of the use of seclusion and restraint in New Zealand, Shalev (2017) expresses concern about the high use of segregation in prisons. 'In the year to 30 Nov 2016, there were 16,370 recorded instances of segregation in New Zealand' prisons (Shalev 2017, 25). This is a rate of 167.1 per 100 prisoners, which is four times higher than the rate of segregation in England and Wales, where the rate 'was found to be high' (Shalev 2017, 25). Further, data provided to me under the Official Information Act shows that cell confinement, the most extreme form of isolation in New Zealand prisons, was used 6706 times in financial year 2013/14, 6021 times in 2014/15 and 6609 times in 2015/16 (Leota 2017a). It is a routine practice in New Zealand prisons, with prisoners being punished to cell confinement on average 17.66 times per day from 2013 to 2016.

Shalev argues that much of the segregation in New Zealand prisons amounts to solitary confinement. Shalev defines solitary confinement as 'the social and physical isolation of individuals in a place of confinement for twenty-two to twenty-four hours a day' $(2017,16)$. She comprehensively outlines the detrimental effects of solitary confinement. Solitary confinement can have acute to chronic psychological effects, as well as detrimental 
physiological effects, including 'migraine headaches, heart palpitations, back and other joint pains, gastro-intestinal and genito-urinary problems, excessive sweating, insomnia, deterioration of eyesight, lethargy, dizziness, weakness and profound fatigue, feeling cold, poor appetite, weight loss, diarrhoea, tremulousness and aggravation of pre-existing medical problems' (Shalev 2017, 17).

Although prisoners have a higher rate of suicide than the general population (Fazel et al. 2011; Ong and Lynch 2016), prisoners in solitary confinement experience an even higher rate of suicide than prisoners generally (Hayes 1995; Anasseril and Fleming 2006; Fatos et al. 2014). Shalev notes that although 'solitary confinement can be damaging to those with no previous history of mental health issues, individuals with pre-existing mental illness are at a particularly high risk of worsening psychiatric problems as a result of their isolation' $(2017,18)$.

The concept of the subject that I outline in this thesis demonstrates how solitary confinement is fundamentally dehumanising. As I detail in chapter 1, for Butler, the subject is always incomplete, fractured, and can never be understood as simply an 'individual'. The subject is always-already social. Subjects are 'constituted in and by a social world' (Butler 2015a, 108). A subject's attempt to make sense of itself, although never fully achievable, can only occur in relation to others. When one is denied access to sociality other than its embodiment in one's captors, one is denied a fundamental aspect of one's humanity. Solitary confinement, in this way, not only cuts off the subject from others but also to themselves. 
Solitary confinement is, therefore, a form of extreme abjection from an already-abject zone of incarceration. It is a place to cast off the people who Corrections deems to be too dangerous, too mentally unwell for mainstream imprisonment, or in need of even more severe punishment. Solitary confinement undermines the sociality of the self, denying the bodies exposed to it of their fundamental need for the other. It causes severe damage to those bodies and puts them at greater risk of taking their own lives. Thus, solitary confinement, as a normalised practice within New Zealand prisons, reproduces the norms of dehumanisation by denying the bodies exposed to it their fundamental human sociality, while placing them at higher risk of harm.

As detailed above, Tipene Pomare was exposed to this dehumanising practice in the lead up to his death. He was denied access to other people for at least the first 10 days of his isolation and was, most-likely, confined inside for up to 24 hours per day. Tipene was held in conditions that amounted to solitary confinement and took his own life on the $13^{\text {th }}$ day of his confinement. In this way, Tipene's treatment is a single iteration of a larger disciplinary regime where solitary confinement is a normalised practice in New Zealand prisons.

Despite what appears to be cruel and inhuman treatment of Tipene, Coroner Evans is not convinced that his segregation status was a factor in his death. 'Whether or not his Directed Segregation was a factor influencing his decision to take his life cannot be known. Nor can it be known whether the earlier revocation of a prohibition upon his associating with other prisoners might have had a beneficial effect' (Evans 2015, para. 50). Coroner Evans was, in this way, unwilling to question how the dehumanising treatment of Tipene made him more susceptible to taking his own life. In this instance, the state refuses to consider how its actions may establish zones of abjection that place those in its care at greater risk of death. 
There are, of course, further cases in which prisoners took their own lives while enduring Directed Segregation or cell confinement. However, because of the strict censorship regime on the particulars of self-inflicted deaths, I am unable to detail other cases of self-inflicted death of people experiencing this type of solitary confinement. I hope that that censorship, given the disproportionate rate of suicides in solitary confinement internationally, speaks volumes about the dehumanising practices in New Zealand prisons.

\section{At-Risk Unit}

A second form of isolation that can amount to solitary confinement in New Zealand prisons are the At-Risk Units (ARUs). The ARUs 'comprise of solitary cells where prisoners are transferred in efforts to prevent the risk of personal harm or injury to themselves' (Harris 2015, 40). ARUs play a vital role in almost all coroners' findings into self-inflicted deaths. Many of these findings start with the assumption that 'good strategies' for managing suicidal people is to place them in a 'suicide-proof' ARU. Many findings discuss at length the various at-risk assessments that prisoners underwent during their incarceration. The purpose of this is to determine if a mistake was made in failing to place the deceased in the ARU.

For example, in the case of Daniel Barry, the coroner quotes and accepts prison Inspector Longmuir's statement that 'Daniel's death may well have been prevented had all the information in the prison's possession at the relevant time been made available to the staff responsible for deciding Daniel's At Risk status' (Longmuir quoted in Devonport 2010b, para. 95). Coroners and Inspectors, in their obsession with the at-risk assessments, attempt to 
uncover if the deceased should have been in an ARU based on the information at hand, and if there was any other pertinent information that was not considered that would have meant the deceased was considered at-risk. This, of course, presupposes that if the deceased was in the ARU, they may not have died.

Coroners' acceptance of Corrections' assumption that suicidal people should be housed in ARUs demonstrates the coroners' implicit acceptance that the practices in ARUs are necessary. Yet the conditions in ARUs have been exposed as degrading and inhumane. In a 2016 report, the Chief Ombudsman finds that the ARU at Invercargill prison 'does not promote wellness for either staff or prisoners' (Boshier 2016a, 18). Shalev similarly finds that 'the appearance, conditions and regime in most of the At Risk units we visited were as impoverished and stark as those in punitive segregation units and units for the management of difficult prisoners. Since segregation is a known risk factor for self-harm and suicide, it follows that the people at risk of such behaviour should not be segregated' (Shalev 2017, 34). According to Harris' (2015) study of ARUs, prisoners are locked in ARU cells for up to 23 hours per day. The National Health Committee also finds that people 'in at-risk units have no access to the outside world, no fresh air, and almost no human contact' $(2010,35)$.

Coroner Scott's discussion of the ARU and suicide-proof cells is a refreshingly candid account of the state's approach to suicidal prisoners. Coroner Scott states 'At the hearing, counsel for $[\text { Piri's }]^{36}$ family asked a senior prison officer if prison cells could be made totally safe or suicide-proof. The answer that he received was "yes but only by dehumanising the cell

\footnotetext{
${ }^{36}$ Piri is not the real name of the deceased. I used the name Piri, as the coroner prohibited the publication of the deceased's name under $\S 74$ of the Coroners Act 2006.
} 
environment or [sic] the prisoner". He went on to describe how this in fact could be done and how in fact it was done in a very limited number of high risk cells' (2012c, para. 26). This is a clear admission by Corrections and acceptance by the coroner that there are dehumanising cells in New Zealand prisons. Coroner Scott then comments that imprisonment in suicideproof cells 'would be a grossly excessive extra penalty to impose on prisoners' (2012c, para. 28). ${ }^{37}$

Coroner Scott states 'I have very strong views on anything which tends to make prisons any more dehumanised than they must be to secure the population' (2012c, para. 28, emphasis added). In these striking paragraphs, Coroner Scott states that suicide-proof cells are dehumanising and a grossly excessive penalty on prisoners. He also rejects the dehumanisation of prisoners any more 'than they must be'. Implicit in these contradictions is the recognition that prisons must dehumanise incarcerated people in order to 'secure the population'.

In practice, the conditions and extreme isolation in ARUs can amount to a severe form of solitary confinement. However, coroners and Corrections presuppose that because ARUs save lives, the dehumanising treatment experienced within them is acceptable. Harris argues that 'the prevention of death at a managerial level is prioritised above any attempts to remedy prisoners' underlying ailments or to treat prisoners as human beings. It is within this context that bare and isolating ARUs can be viewed as legitimate' (2015, 34). Importantly, although ARUs

\footnotetext{
${ }^{37}$ That being said, in other cases of self-inflicted death, Coroner Scott (2012a, 2016b) considers the deceased's at-risk status or whether they should have been in an ARU.
} 
dehumanise the people who endure them, suicides still occur in these supposedly suicideproof cells.

Probably the most widely reported prison death in New Zealand media, the death of Antoine Dixon, happened while he was in an ARU (Evans 2013). Antoine took his own life while a prisoner at Auckland Prison in 2009. Although Antoine had been in prison for several years prior to his death, the convictions for which he was originally imprisoned were overturned on appeal. He was retried, found guilty, and was on remand-waiting-sentence. One day prior to his sentencing, Antoine died.

Several elements of the circumstances of Antoine's death are shocking, none more so than the way he was treated in the lead up to his death. During his period on remand since 2008, Antoine spent almost the entire time at Auckland Central Remand Prison (ACRP). The coroner comments that Antoine's mental health deteriorated while at ACRP, leading to an apparent suicide attempt on February 1, 2009. As a result of this incident, officers placed Antoine in the ARU in waist restraints, 'meaning that his hands were handcuffed to a belt around his waist' (Evans 2013, para. 21). The handcuffs created severe discomfort for Antoine, causing cellulitis which required intravenous anti-biotic for treatment. Antoine never received this treatment 'due to logistical difficulties in taking Mr Dixon to hospital' (Evans 2013, para. 54). He was in waist restraints for thirty-one uninterrupted hours.

On February 2, 2009, Antoine was transferred to Auckland Prison because there was a tiedown bed in that prison's ARU. The tie-down bed and waist-restraint are two of the most 
punitive technologies that are used in ARUs. Antoine was placed in a tie-down bed until the afternoon of February 4. Inspector Aumua told the coroner that since Antoine's 'placement in waist restraints and on the tie-down bed he had access to drinking water only when staff provided it. He said no record was maintained in relation to the times food and water were offered to Mr Dixon and whether such food or water were accepted or refused' (Evans 2013, para. 32).

Dr Pillai, a forensic psychiatrist, saw Antoine while he was in a tie-down bed on February 3. Dr Pillai was highly concerned about the use of the tie-down bed. Dr Pillai found Antoine was exhibiting features of delirium, 'secondary to a number of causes, including his deteriorated physical state (infection and dehydration), sleep deprivation and ongoing restraints' (Evans 2013, para. 54). Dr Pillai recommended that Antoine be removed from the tie-down bed, telling Coroner Evans that 'the tying-down of people on beds to manage the risk of self-harm is not something that happens in a mental health context. He said he and his colleagues feel very uncomfortable about such practice' (Evans 2013, para. 64). Antoine was removed from the tie-down bed on the afternoon of February 4.

Coroner Evans details extensive evidence from Dr Pillai into Antoine's mental health history. Antoine had been admitted to the Mason Clinic, a secure forensic mental health unit, on two occasions and had experienced drug-related issues and psychotic episodes. He was described by Dr Pillai as difficult to assess as he was supposedly an 'adept liar' (Evans 2013, para. 18). Dr Pillai considered admitting Antoine to the Mason Clinic after his assessment on February 4, but 'anticipated challenges' to his admission as 'the clinic runs at greater than 100 percent occupancy' (Evans 2013, para. 55). No action was taken at that time and Antoine died that 
evening. Evidence provided by Corrections and Dr Pillai concluded in retrospect that Antoine should have been in the Mason Clinic. Coroner Evans comments that if Antoine had been at the Mason Clinic, 'the use of a tie down bed might have been avoided' (Evans 2013, para. 64).

Once Antoine was removed from the tie-down bed, he was placed in a 'tear proof' stitch gown in the ARU and placed under fifteen-minute observations, meaning an officer needed to physically check him every fifteen minutes. On the evening of February 4, a Corrections officer, 'heard a thump and went to Mr Dixon's cell, he saw him standing behind the door holding a cord around his neck' (Evans 2013, para. 46). The Corrections officer, however, did not open the cell at the time, even though he had the key. Instead, he waited seven minutes until three other officers arrived before he opened the door. In that time, the officer saw Antoine collapse. The officer waited for three other officers, as the prison's policy was that Antoine's cell was not to be opened without four officers present.

Coroner Evans is highly critical that Antoine's cell was not opened immediately, as Corrections' Policy and Procedure Manual at the time stated that where a prisoner is in 'imminent danger', a single officer could open the cell. ${ }^{38}$ Coroner Evans saw this as a policy failure, given that the Corrections officer who found Antoine self-strangulating was not aware of the imminent danger provision. ${ }^{39}$ Because Antoine would have been under 'continuous supervision', as well as it being likely that it would not have taken as long to respond to the

\footnotetext{
${ }^{38}$ As enabled under section B.03.02 of the then-Department of Corrections Policy and Procedure Manual.

${ }^{39}$ Importantly, in many other cases of death during hours of lock up, the coroner does not criticise length of time it took for the cell to be unlocked. In the case of Richard Barriball, Coroner Crerar uncritically states that the cell was not opened immediately because prison 'protocols require sufficient staff to be available, and present, before an occupied cell is entered' (2012a, para. 13).
} 
self-harm, Coroner Evans comments that had Antoine 'been moved to accommodation in the Mason Clinic or other mental health unit, it is unlikely that he would have died' (Evans 2013, para. 108).

Corrections' response to Antoine's death provides some other important insights. In a Memorandum of Understanding between the Department of Corrections and the Ministry of Health cited by Coroner Evans, a guiding principle of the memorandum is that "prisons are not the most appropriate environment to assess and treat acutely mentally unwell prisoners' (Department of Corrections and Ministry of Health 2008, 1-2). ${ }^{40}$ The claim that prisons are not appropriate places to treat mentally unwell people is supported by multiple Ombudsman (Wakem and McGee 2012) and other investigations into New Zealand prisons (National Health Committee 2010; Stanley 2011; Shalev 2017). Recognising this, however, it is troubling that Corrections continues to see tie-down beds as a necessary measure to restrain acutely mentally unwell people (A. Weber 2017), despite reports finding them to be 'inherently degrading' (Shalev 2017, 9), and amounting 'to cruel, inhuman or degrading treatment or punishment' (Boshier 2017a, 5). ${ }^{41}$

In Antoine Dixon's case, Corrections officials continually stressed the necessity of treating Antoine in a dehumanising manner, such as the waist restraints and tie-down bed. After outlining Antoine's offending in the first paragraph of his findings, in the second, the coroner states

\footnotetext{
${ }^{40}$ I received this memorandum of understanding as a part of an Official Information Act request (Field 2017).

${ }^{41}$ For an excellent analysis of Corrections' use of tie-down beds, see Elizabeth Stanley's (2017) “"Risk prevention" just won't wash. Torture in prisons is torture, and we need to act now'.
} 
Mr Dixon had a history of unpredictability, aggressiveness and selfharming. On occasions, he had appeared to be compliant, but on other occasions his behaviour was described as extreme and manipulative. He was regarded as a high-risk prisoner who demanded the strictest management regime, in order to ensure the safety of both himself and of those who came into contact with him. (Evans 2013, para. 2)

Within this context, the bed and waist restraints were described by officials as the 'only option' (para. 29), 'the most appropriate place for Mr Dixon' (para. 29), and 'reasonable and practical' (para. 84).

In cases such as Antoine's, the state sees him as 'difficult to manage' (Evans 2013, para. 84). Butler argues that 'one way of "managing" a population is to constitute them as the less than human without entitlement to rights, as the humanly unrecognizable' (2006b, 98). Managing such a population is "not only a process through which regulatory power produces a set of subjects. It is also the process of their de-subjectivation' (98). The Department of Corrections often reiterates that its very purpose is to 'manage' a difficult population. In the 2016 'Briefing to the Incoming Minister', Corrections' Chief Executive begins his message to the Minister, stating 'I am proud to lead an organisation that has a great passion and commitment to managing some of New Zealand's most difficult individuals' (Smith quoted in Department of Corrections 2016b, 3). For Workman and McIntosh, such thinking suggests that prisoners 'are no longer individuals who could potentially be reintegrated but risks to be carefully managed' $(2013,126)$. 
Particularly unmanageable prisoners are placed in even heightened precarity. Prisoners who are forced into Directed Segregation or cell confinement, as a way to manage them as a threat to prison security or punish them for misbehaviour, are exposed to the dehumanising practices of isolation. For prisoners like Antoine Dixon, inhumane and degrading practices such as waist and bed restraints are the technologies through which their basic bodily movement is restricted, as a way to mitigate risk. In other words, because prisoners are abject beings and part of a population that needs to be managed, practices that dehumanise prisoners re-enact the normative presupposition that prisoners are not human. These practices reproduce the ideal that these abject bodies are worth less than human bodies within the normative regime.

These norms of dehumanisation are often unrecognisable as dehumanising by the state officials who enact them. In the case of Tipene Pomare, Corrections officers merely repeated routine practice in his treatment of segregation. It was routine for a person at Rimutaka Prison who was placed on Directed Segregation to be isolated for the statutory maximum of 14 days. It was routine for the prisoners on Directed Segregation to be denied association with any other prisoners for the first 10 days of their isolation (Evans 2015). In becoming a routine practice, dehumanising conditions of confinement and isolation become regular or normalised. This normalisation makes it difficult for those subjects who practice it to understand how an everyday prison practice could be fundamentally dehumanising. These practices are, however, simultaneously exceptional practices in that their routinisation reinstates the exception to the category of the human.

As Butler argues, 'Violence against those who are already not quite lives, who are living in a state of suspension between life and death, leaves a mark that is no mark' $(2004,25)$. This 
process is apparent in the treatment of prisoners in the cases I have identified thus far. Because prisoners have been cast out into the abject zones of imprisonment, they are readied for dehumanising treatment. While in prison, norms of dehumanisation, such as practices of isolation, restraint, denial of status as workers, and denial of bodily autonomy, reproduce the prisoner as a subject that is not quite human. It is in these everyday practices of dehumanisation that prisoners' abjection is validated. When weighed against the need to 'secure the population', as Coroner Scott (2012c, para. 28) comments, prisoners are necessarily dehumanised. However, given the normalisation of inhuman and degrading treatment, this violence is done to bodies that are not quite human and that normalised violence cannot be recognised as violence against a person. 


\section{Vulnerability and the Distribution of Precarity}

As social animals, we are all fundamentally dependent on others to survive. Vulnerability, for Butler, is a way of relating to others and our social conditions. It is 'a mode of relationality' (Butler 2015a, 130). Because one's continued existence depends on social conditions that support that existence and those social conditions must be continuously reproduced, bodies are always vulnerable. Butler argues, 'If I am someone who cannot be without doing, then the conditions of my doing are, in part, the conditions of my existence' $(2004,3)$. As one's sustenance can never be achieved once and for all, one's continued existence depends on relations to others that continue to sustain that existence. That dependency exposes the body to exploitation, neglect, and violence, where the threat of withdrawal of those conditions or the withdrawal itself puts the body at risk.

People who find themselves in prison are heavily dependent on their captors for their continued survival. The state is ultimately responsible for the social conditions of imprisonment. Large parts of the daily lives of incarcerated people are determined by the state. It decides what and when the prisoner will eat, how they will be housed, with whom they will be allowed to interact, what they will do with their time, and what kind of care will be provided. ${ }^{42}$ The social environment in which prisoners live is marked by violence and encourages damaging behaviours (National Health Committee 2010). What is done to prisoners by the state and the social conditions of the prison exploits their fundamental vulnerability by exposing them to conditions that undo them as humans.

\footnotetext{
${ }^{42}$ There are exceptions to this principle in units such as self-care units (Vaccarino et al. 2009).
} 
The dependency of prisoners on their captors heightens their vulnerability, particularly for those who are unwell. People who are unwell in prison are dependent on the Department of Corrections for their healthcare. Although the Department of Corrections only directly provides primary healthcare, prisoners' access to secondary and tertiary care is dependent on the Department's willingness to provide access to that care (Department of Corrections 2016d).

Prisons and prisoners, although existing at the margins of society, are inseparable from the settler-colonial capitalist context in which they emerge. In a 2010 report, the National Health Committee (2010) finds that prisoners largely come from impoverished communities that have some of the poorest health outcomes in New Zealand. Indeed, the social conditions that disproportionately push Māori and the poor into prisons are the same social conditions that expose people outside prison to poor health outcomes. As I argue in the previous chapter, the prison is a zone of abjection that exposes prisoners to norms of dehumanisation. The prison is, of course, not the only zone of abjection, as colonial capitalist norms that deny sustenance to certain bodies exceed the prison. The medical treatment of people in the lead up to their deaths in prison are, in this way, cases of exceptional dehumanisation and heightened vulnerability that expose wider conditions of dehumanisation.

\section{Healthcare}

Some coroners' findings outline how social and physical conditions of prisons heighten the vulnerability of unwell prisoners. This understanding, however, in many cases requires reading the material practices against the coroners' acceptance of the healthcare provided. 
Coroners often uncritically adopt the findings of Death in Custody reports from Inspectors of Corrections in the assessment of a prisoner's quality of healthcare. In most cases where an assessment of a prisoner's healthcare is relevant to the circumstances of the death, the coroner finds that the prisoner received an acceptable or even high quality of care. Coroners usually draw this conclusion from the Inspectors' reports.

The purpose of the Inspectors' reports into a death in custody is to investigate the circumstances of the death and to assess whether there was compliance with the Corrections Act, Regulations, and the Prison Operations Manual, or its equivalent (Ryan 2012b; Crerar 2015). Regarding healthcare, the Corrections Act s 75(2) states that the 'standard of health care that is available to prisoners in a prison must be reasonably equivalent to the standard of health care available to the public'. Particularly in cases of natural death, the quality of healthcare that the deceased received while in prison is a relevant standard for the Inspector to assess.

Coroners often state something to the effect of: the 'report from Mr David Morrison, Inspector of Corrections, notes that Mr Jarden, as a prisoner with significant health issues, was well managed. He received the level of care and treatment which was at least equal to that which he would have received had he been in the community' (McElrea 2011, para. 7). In this instance, Coroner McElrea repeats almost word for word the legislative standard by which the Inspector must assess the deceased's quality of care. Similarly, Coroner Evans states Inspector 'Riddle satisfied himself that the level of healthcare provided to Mr Kauhau, "was consistent with and probably exceeded the level of care he would have received in the community." The Court accepts that finding' (2012, para. 8). 
The notion that the quality of care in prison exceeded the quality of care in the community appears in several cases. Coroner Scott finds that Miller Haapu received care 'that it was at least as good - quite possibly better than that which he would have actively sought for himself had he been a member of the general Wanganui community' (2012d, para. 13). In the case of Stephen Wells, Coroner McElrea states that Inspector 'Longmuir's overall finding was that throughout the period of imprisonment Mr Wells received a very high standard of care from Christchurch Men's Prison health services staff' (2013, para. 13), before saying 'I endorse those findings' (para. 14).

While it may be accurate that the vast majority of people who died while in prison received a level of care equivalent to the quality in the community, given other recent reports into healthcare in New Zealand prisons, that claim seems dubious. ${ }^{43}$ In 2012 , the Office of the Ombudsman's report into healthcare in New Zealand prison finds that Correction's provision of dental care was 'inadequate', and 'Mental healthcare appeared inadequate or unsuitable' (Wakem and McGee 2012, 112).

Similarly, recent reports produced by the Ombudsman with its authority granted by the Crimes of Torture Act, reveal an appalling standard of care in New Zealand prisons. ${ }^{44}$ In response to a questionnaire, $60 \%$ of prisoner respondents at Invercargill Prison (Boshier 2016a), 62\% at Otago Corrections Facility (Boshier 2016c), and 66\% at Spring Hill Corrections Facility

\footnotetext{
${ }^{43}$ It is also possible, because the standard is an equivalent standard measured against community healthcare, that community healthcare is poor enough that the poor treatment of prisoners is nonetheless equivalent.

${ }^{44}$ For an abolitionist discussion of the Ombudsman's COTA reports, see No Pride in Prisons' Torture in New Zealand Prisons: A Briefing (Lamusse 2017a).
} 
(Boshier 2017c) said it was either 'difficult' or 'very difficult' to see a doctor. Further, $42 \%$ of Otago, $42 \%$ of Spring Hill and $43 \%$ of Invercargill respondents stated that the overall quality of care their received was either 'bad' or 'very bad'.

In the coroners' findings, many of those who died of natural causes had long-term disabilities or illnesses. It is striking, therefore, that $64 \%$ of Invercargill, $69 \%$ of Otago, $77 \%$ of Hawke's Bay Prison (Boshier 2017b), and 80\% of Spring Hill respondents said they felt unsupported in their disabilities. Given that $34.26 \%$ of the deaths in the cases I have were self-inflicted, it is particularly concerning that $72 \%$ of Otago, $74 \%$ of Manawatu (Boshier 2016b), and $78 \%$ of Invercargill respondents did not feel supported in their mental health needs.

Finally, a 2012 Ministry of Health-commissioned report finds that prisons are detrimental to the health of incarcerated people. It finds that

Risks to prisoners' physical and mental health are significant. These risks arise from of all aspects of prison life: the physical environment, the prison culture, and the behaviours people develop to survive prison. The more time people spend in prison, the more likely their mental and physical status will deteriorate (National Health Committee 2010, 5)

Given this wider research environment, which is highly critical of the healthcare provided to prisoners, I remain unconvinced by coroners' and Inspectors' claims that the deceased received high quality of care in the lead up to their deaths. 
However, in some instances, coroners expose some appalling health care practices. The coroner's finding from Glenn Mills' death, who took his own life while a prisoner at Mount Eden Men's Prison (MEMP), uncovers some serious healthcare failures. ${ }^{45}$ Glenn was a highprofile prisoner because of the well-publicised nature of his accused offending. Glenn was HIV positive and suffered many HIV-related illnesses while remanded in custody.

Glenn spent most of his time in prison in Auckland Central Remand Prison (ACRP) and was moved to MEMP three and a half weeks prior to his death. Coroner Greig finds, that during the time he was in MEMP, Glenn was not given his daily anti-depressant medication on at least four occasions, 'and that he had not been administered medication for three days of the last week of his life' (2012b, para. 36). Glenn 'asked Corrections Officers for the medication on occasion, but it had not been forthcoming' (para. 36). Nonetheless, Coroner Greig states that one of Inspector McDonald's findings from her investigation into Glenn's death is that Glenn 'received a high level of health care and treatment' (2012b, para. 44). Coroner Greig does not explicitly reject this finding but comments that the administration of medication was 'not of an appropriate standard' (2012b, para. 76).

Evidence from the Health Centre Manager at the time at ACRP and MEMP, Shirley Willet, reveals that the failure to administer medication was not an issue isolated to Glenn. As some of the medication was not given to Glenn when he was transferred between prisons, Willet 'stated that it was not uncommon for medication not to be transferred at the same time as a prisoner' (Greig 2012b, para. 78). Following Glenn's death, it was also discovered that

\footnotetext{
${ }^{45}$ Mount Eden Men's Prison is now closed.
} 
prisoners often did not receive their morning medication when they were transferred to Court. Willet's evidence demonstrates 'that such prisoners were missing out on their morning medication as there was not a proper process in place to ensure they received it', which Coroner Greig refers to as a 'systems failure' (2012b, para. 78).

Coroner Greig finds that the broader medical treatment of Glenn 'preyed on his mind' (2012b, para. 76) when he took his life. Glenn told his lawyer, and wrote in a letter he left in his cell, that the failure to provide him with his medication was 'symbolic of inefficiencies in health delivery at MEMP and that he could not rely on the staff there for appropriate care' (Greig 2012b, para. 76). Glenn's lawyer 'stated that Mr Mills found being in custody particularly hard and that his medical condition... increased his difficulties' (Greig 2012b, para. 42).

Gaileen Codlin also did not receive prescribed anti-depressant medication for the first eight days of her imprisonment. Although she died of a heart attack, Gaileen's family was concerned that the failure to administer anti-depressants may have been detrimental to her health and contributed to her death. In a findings that quotes extensively from an Inspector's report, Coroner Jamieson says, 'I heard no evidence which might have assisted me in so deciding' (2009b, para. 4.1) if the medication failure had an adverse effect on Gaileen's health. Although Coroner Jamieson did not come to a conclusion on the family's concern, he nonetheless finds that 'the management at AWCF of Ms Codlin's anti-depressant medication was disorganised and unsafe' (2009b, para. 4.1). 
Michael Grant died of heart failure while incarcerated at Invercargill Prison after twelve days of imprisonment. Michael did not see a medical officer at all during that time, although he was scheduled to see one multiple times, in recognition that he was unwell. Michael's family expressed concern that "when Michael Grant had been asking for his medication and to see a doctor, this was delayed' (Crerar 2012b, para. 16). Although Coroner Crerar finds that this was 'sub-optimal' and 'ideally, Corrections ought to have ensured a medical appointment' (2012b, para. 35), the coroner ultimately agrees with Inspector Longmuir's findings that there was 'no failure by Corrections' to provide Michael with 'appropriate care' (2012b, para. 29). There appears to be an ongoing issue with waiting times to see a doctor at Invercargill, as the Chief Ombudsman finds in a 2016 report that waiting times for a doctor at the prison 'were between one and three weeks' (Boshier 2016a, 37).

In the case of Saomalie Toailoa, the family was concerned that Saomalie, who had been terminally ill for months prior to his death and required constant care, was very thin and dehydrated at the time of his death. In response, Coroner na Nagara states that 'As to the family's concern that Mr Toailoa was dehydrated, I acknowledge that the post mortem findings were that he was suffering slight dehydration, but not at a level that was life threatening' (2016, para. 50). Implicit in this statement is that because Saomalie did not die from dehydration, the fact that he was dehydrated was irrelevant. Instead of seeing this as a form of maltreatment of someone who was wholly dependent on prison medical staff, Coroner na Nagara agrees with the Inspector's assessment that Saomalie 'received appropriate care' (2016, para. 56). 
In this case, Saomalie was so thoroughly dependent on Corrections that he needed officers to give him food and water. This, clearly, was not provided sufficiently. A similar dependence and failure of support is also clear in Antoine Dixon's case (Evans 2013). Antoine was dehydrated while in a tie-down bed and waist restraints, and experiencing psychosis, according to his psychiatrist. While he was in waist restraints and a tie-down bed, Corrections staff did not record how often he was provided water. It is unclear how often, if ever, Antoine was given water by Corrections officers.

Prior to taking his life while a prisoner at Otago Corrections Facility, Richard Barriball injured his arm while in the community and suffered severe pain as a result. While in the community, he was prescribed Tramadol for his pain. On reception at the prison, this prescription was changed by the prison doctor to dihydrocodeine (DHC) 'for the convenience of prison management' because DHC 'could be administered to prisoners more freely than could Tramadol' (Crerar 2012a, para. 23). Following insistence from Richard to restart the Tramadol, he was once again prescribed Tramadol, four days after it had been cancelled. However, Richard was not given Tramadol in the evenings because of staffing shortages.

In messages for his family, Richard expressed that he was feeling significant pain, which while under control in the community, was exacerbated by the changes to his medication made by a prison doctor and the failure to administer his evening Tramadol. Coroner Crerar (2012a, para. 68) considers his level of pain to be a 'stressor' that caused him to take his life. Regardless, the Inspector Longmuir finds that Richard 'received a level of medical care and treatment which was at least equal to that which would have been received had he been in the 
community' (Longmuir quoted in Crerar 2012a, para. 41). Coroner Crerar explicitly rejects this, finding that Richard received 'suboptimal care' (2012a, para. 75).

In a striking comment, Coroner Crerar effectively admits that healthcare in prisons is inherently insufficient. Security was part of the reason that Richard's Tramadol prescription was initially cancelled. Medications like Tramadol could not be self-administered in prison, because of the fear that it would be traded. Coroner Crerar thus notes that "most people in the community self-administer prescribed medication but, in a prison environment, a number of medications have a value (a trading value) so it is not practicable for Corrections to leave medication with prisoners to self-administer' (2012a, para. 43). Because prisoners are not able to self-administer some medication, which medical officers admit affects the medications they prescribe, their standard of care is inherently inferior to the standard in the community. Therefore, 'the ability of Corrections and its management to provide such services is compromised by security constraints' (Crerar 2012a, para. 75).

Other cases reveal that the primacy of security over care causes many other restrictions to adequate healthcare. James Kahu died from heart failure while at Whanganui Prison. Two years prior to his death, he presented at medical complaining of a pounding heart. He was scheduled to see a heart specialist shortly thereafter. However, because James was transferred to another prison prior to the appointment, he was unable to attend it. James was not informed as to the time and date of the appointment. As Coroner na Nagara notes, 'an important point of distinction between prisoners and those in the general population is that while the general public are communicated with directly about appointments in the public health system, this does not appear to be the case for prisoners' (2008, para. 55). 
The former Regional Health Services Manager at Whanganui Prison, Barbara Corner, 'advised that prisoners are not advised in advance of any appointment that they have outside the prison "for obvious reasons. We don't want them knowing that they're going out on this specific date"' (Corner quoted in na Nagara 2008, para. 56, emphasis added). The obviousness here betrays the underlying philosophy of healthcare provision in prisons. 'Services are provided in an environment dominated by a focus on security' (National Health Committee $2010,10)$. It is a taken-for-granted necessity that the security of the prison, and the population that prisons are supposedly protecting, takes precedence over the well-being of imprisoned people. In this way, their vulnerability is exploited, as they are put in a position of heightened precarity, for the reason of protecting those worthy of protection.

\section{Distribution of precariousness}

Because of our fundamental exposure to a world of others and our dependence on that world to sustain us, human life is inherently precarious, at risk of destruction. What matters for the purposes of sociology and politics is not this generalised condition of precariousness but how that precariousness is distributed (Butler 2006b, 2010, 2015a). Precarity, in Butler's terms, is slightly different from precariousness. Precarity is the effect of the heightened precariousness of certain bodies, the condition in which certain bodies 'become differentially exposed to injury, violence, and death' (Butler 2010, 25).

Prisoners, by virtue of inhabiting an abject zone, are placed in situations of heightened precarity. As demonstrated in relation to healthcare, this distribution of heightened precarity 
to prisoners is, in part, justified by the need to maintain 'security'. The primacy of security is presupposed in many of the coroners' responses to what would otherwise be recognised as dehumanising and unacceptable treatment.

Walter Napier's ${ }^{46}$ case (Scott 2013) exemplifies this. Walter was remanded at Hawke's Bay Regional Prison (HBRP) prior to his death from natural causes. During his period on remand, he was confined in a 'round room', a type of room within the At-Risk Unit 'designed to provide a segregated environment for the management of violent or very disorientated prisoners. Round rooms usually contain little, except a mattress and bedpan' (Wakem and McGee 2012, 99).

Coroner Scott comments that Walter's 'mental health condition deteriorated significantly while on remand in prison' (2013, para. 3). Three days prior to his death, he was diagnosed as being in a catatonic psychological state. As a result, a prison psychiatrist decided that Walter needed to be transferred to a psychiatric hospital in Porirua. Before travelling to Porirua, Walter was not thoroughly examined as to his physical health and fitness to travel by the prison doctor, even though he was not eating and was drinking little-to-no water. He was not examined because he was deemed to pose a security threat to the doctor.

The day before his transfer to Porirua, HBRP staff decided to transport Walter in a secure prison van. This option was chosen instead of an air ambulance, road ambulance, or a car. A

\footnotetext{
${ }^{46}$ I have used the name 'Walter Napier' as a placeholder in this case. Walter's real name was barred from publication under $\S 74$ of the Coroners Act 2006.
} 
Corrections doctor deemed that all modes of transportation other than a secure prison van posed 'security and safety concerns' (Scott 2013, para. 12). In the prison van, Walter was 'placed in a small individual cell sitting upright on a padded seat. Foam padding was placed on either side of him to stop him from falling from the seat and a helmet was placed on his head. There was no seatbelt' (Scott 2013, para. 13). Although Coroner Scott comments that this 'was a demeaning way to transport a highly vulnerable inmate', he also finds that 'this form of transport was adequate' (2013, para. 14). The implication of this statement is that it is adequate to treat prisoners in this demeaning way.

While in the van cell, Walter's condition could not be easily ascertained and was checked only every half hour. At approximately 9:40 on the day Walter died, a Corrections officer in the van noticed that Walter was slumped on the front of the cell. As the officer was concerned about Walter, the van detoured to Manawatu Prison to check on him 'in a secure environment' (Scott 2013, para. 20). When the van arrived at Manawatu, the nurse travelling in the van merely tapped on the window of his cell to get a response, without conducting a thorough check-up. At Manawatu Prison, the prison officers in the van stopped to use the bathroom and to have coffee, while Walter was left in his van cell.

After the van left Manawatu, it stopped again at a petrol station in Levin. At this point, the nurse went to the back of the van again to tap on the window and assess Walter's responsiveness. When the nurse did this, Walter did not respond, so the van was further diverted to the Levin police station where his cell could be opened 'securely'. When his cell was opened, it was clear that Walter was dead. He died of heart failure. 
Coroner Scott comments that the coffee break at Manawatu Prison was 'unacceptable and demeaning' (2013, para. 24). He is also highly critical that Walter did not undergo a medical assessment by a doctor prior to his travel, given he was unwell at the time. He finds that Walter should have been transported in an ambulance or an ambulance patient transfer vehicle, so that he could be closely monitored throughout the journey. Had this occurred, Walter 'may have survivied [sic]' (Scott 2013, para. 45). Reading Coroner Scott's comments together, he finds it was adequate that Walter was transported in a prison van, even though it was demeaning and another transportation method may have saved his life. This suggests that it is adequate that Walter was demeaned and that his life was lost, as a result.

The normative regime that interpellated Walter as an abject being readied him for demeaning treatment. The priority of security over Walter's life and dignity means he was exposed to heightened precarity, failing to provide conditions to sustain his life. When this treatment was inflicted upon his body, the state was able to accept this treatment as adequate, as it was inflicted on an abject body and for the security of those bodies worth protecting.

Similarly, Jai Davis' case starkly demonstrates the disposability of those bodies that threaten the security of the prison. When I received the 113 coroners' findings from the Coronial Office, the file I had for Jai Davis was three pages long, containing only the Certificate of Findings. From the Certificate, it was clear that there was a longer finding that was not attached. Upon request, the Coronial Office then gave me the full finding, which was the longest and most 
comprehensive finding I received, at 106 pages. The mean number of pages for the findings overall is 10.76 .

Jai Davis died from an overdose of diazepam and dihydrocodeine while a prisoner at Otago Corrections Facility (OCF). Coroner Crerar stresses that Jai was regularly engaged in criminalised activities, noting that 'showing the criminal and traffic history of Jai Davis, records 56 convictions between 30 May 1997 and 24 November 2010 for offences including drink-driving, driving whilst disqualified, procuring drugs for supply, other crimes of dishonesty and violence' (2015, para. 29). Prior to Jai's last time in prison, he received a call from a prisoner at OCF, with whom he used coded language to describe his intention to smuggle cannabis, diazepam, and dihydrocodeine into the prison in his rectum.

As calls from prisoner payphones are recorded and monitored by Corrections staff, OCF officials became aware of Jai's plan. On February 10, 2011, Jai handed himself in at the Dunedin Police Station and was transferred to OCF the next day, following a court appearance. OCF officials notified the police that Jai was likely concealing drugs, so the police detained him in a cell without running water and did not allow him to associate with other prisoners. When Jai arrived at OCF, he was immediately taken to the ARU and placed in a round room. Coroner Crerar notes that the round room was used because it was not possible for 'the occupants of such cells to dispose of any items which had been concealed on or in themselves without these becoming immediately identifiable' (2015, para. 19). In other words, the purpose of placing Jai in the round room was to catch him out attempting to smuggle drugs into the prison. Jai was detained in the ARU under section 58(1)(a) Corrections Act 2004, for 'the good order and security of the prison'. 
Jai experienced extremely dehumanising conditions while he was in the round room. It appears that Jai was confined for twenty-four hours a day, as according to a Corrections Officer, 'when prisoners were in the dry/cell [sic] round room at ARU, they would normally be denied yard time' (Crerar 2015, para. 226). This is in breach of the United Nations Standard Minimum Rules for the Treatment of Prisoners (2015), to which New Zealand is a signatory, which mandates that prisoners must have at least one hour of open air daily. ${ }^{47}$ It was, however, only following cross-examination from the family's counsel that Inspector Morrison admitted 'OCF may have denied Jai Davis some of his legitimate entitlements for the period he was in the ARU' (Crerar 2015, para. 300).

Coroner Crerar also notes multiple times that, on February 13, Nurse Horne gave instructions to Corrections officers that Jai be 'woken every hour for a verbal response' (2015, para. 246), which could amount to sleep deprivation if carried out for an extended period. ${ }^{48}$ No further reasoning behind the decision to rouse Jai hourly was given other than that Nurse Horne 'believed for the good care and safety he was to be roused overnight every hour just to make sure he was wakeable' (Horne quoted in Crerar 2015, para. 185). Coroner Crerar, however, comments that, according to Corrections management, any prisoner who needs to be woken every hour for observation should be transferred to a hospital.

\footnotetext{
47 The United Nations 'Standard Minimum Rules for the Treatment of Prisoners', Rule 23.

48 The Corrections officer on duty on the night of Jai's death did not follow the instructions to rouse Jai hourly. The coroner is extremely critical of this, believing that the failure to regularly check on Jai contributed to his death.
} 
As there was no toilet in his cell, Jai was required to defecate in a cardboard potty. The Chief Ombudsman, Chief Custodial Officer, multiple Corrections officers, and a nurse all gave evidence criticising the use of the potty to varying degrees. However, the only reasons given in the finding for why this was inappropriate are concerning. Nurse Horne gave evidence that she was 'surprised' to see Jai was given a potty because she 'understood the protocol was for a prisoner wishing to have a bowel motion to be escorted from the dry cell to the adjacent toilet and that a prisoner was required to have his hands visible at all times' (Crerar 2015, para. 183). A Corrections Officer gave evidence that the potty was 'not ideal' because 'this would give the opportunity for objects excreted to be re-inserted' (2015, para. 272). In other words, the failure in using this cardboard potty was that another humiliating method of obtaining concealed objects in which Jai would have been watched defecating was not used. The dehumanising practice of requiring a person to defecate in a cardboard potty was insufficiently dehumanising for a person being held in a round room. The dehumanising practice was not criticised by the officials or the coroner, as it was a normalised component of at-risk population management.

During his confinement, Jai was asked regularly if he was concealing drugs in his rectum by both Corrections officers and nurses. It was clear to Jai that OCF staff knew of his plot to smuggle drugs, so he started 'consuming the drugs in order to destroy or conceal the evidence' (Crerar 2015, para. 45). On the evening of February 11, Jai's cell was searched and a zip-lock bag was found which contained the remnants of cannabis.

Jai was on regular medical observation from nurses. Nurses noted that he was very drowsy in the lead up to his death. Nurse Scoon admitted to the coroner that the zip-lock bag meant she 
'focused on cannabis ingestion as being the cause of the drowsiness she observed' (Crerar 2015, para. 153). It is clear, however, that Jai received poor medical care prior to his death. Two days prior to his death, a Corrections officer observed that Jai 'was grey-coloured and was scratching badly. His arms were really red. His eyes were sunken and he had the cold sweats' (Crerar 2015, para. 75). However, at no point was a doctor called to examine Jai. Further, when nurses examined Jai, he was not given the privacy to speak freely and frankly to them without the oversight of Corrections officers. The nurses' 'consultations must have been disadvantaged by the inability of a nurse to gain direct access to Jai' (Crerar 2015, para. 191).

The coroner finds that nursing staff were not told by OCF management that Jai was thought to be concealing diazepam and dihydrocodeine, as well as cannabis. Coroner Crerar comments that the "nurses assumed, and could have been entitled to assume, that the symptoms they were observing or were told of were symptoms of the consumption of cannabis. I agree that the omission, by Corrections Intelligence and Corrections Management, to brief the Health Centre Manager and its nurses to the fullest appropriate extent on the facts of the admission of Jai Davis to ARU, was the major failing' (2015, para. 204).

Chief Custodial Officer Beales gave evidence that the 'planning and decision-making for $\mathrm{Mr}$ Davis was focused on security. Mr Davis' health and wellbeing was considered in the context of managing the security risk of contraband drugs getting into OCF' (Crerar 2015, para. 334). Coroner Crerar critically comments that 'Corrections Management were so focused on the apprehension of Jai Davis that there was a general failure by Corrections Management to consider other relevant implications - particularly the safety and health of Jai Davis, during 
his admission' (2015, para. 88). In other words, part of the reason Jai was treated in this manner was because OCF officials were primarily concerned with the security of the prison and obtaining the contraband Jai was concealing. For Coroner Crerar, with 'the knowledge then available to Corrections management, Jai Davis ought to have been admitted direct to hospital and not to OCF' (2015, para. 356). Jai died from an overdose of diazepam and dihydrocodeine, which he consumed to destroy the evidence of his smuggling plot.

While the coroner does partially blame OCF management, and one Corrections officer in particular, he finds 'Jai Davis, himself, is however the person most responsible for the circumstances which led to his death' (Crerar 2015, para. 48). Coroner Crerar's reasoning is that had Jai not attempted to smuggle the drugs into prison in the first place, he would not have died. Left entirely unchallenged in the finding, however, is the criminalisation of cannabis and restriction of access to painkillers in prison. Had there not been a prison environment in which access to these drugs was restricted, there may not have been a black market for the drugs, and there may not have been the impetus on Jai to smuggle the drugs.

Further, from the evidence, it appears that at no point was Jai given the opportunity to hand over the drugs without consequences, as a compromise for his health and safety. OCF officials presented Jai with a highly limited set of decisions. By placing him in the round room, his ability to safely dispose of the drugs without punishment was prevented. He was effectively not given any option other than to consume the drugs to destroy the evidence or hand them over and face the consequences. Given Jai's options, if OCF officials had not placed Jai in a round room, he may not have died. 


\section{Necessary death of the prisoner}

The case of Nicholas Ward Harris contains possibly the most concerning display of a coroner acquiescing to Corrections' position. Although it is not the conclusion Coroner Ryan makes, commentators such as Roger Brooking argue that 'Nicholas Harris was killed by prison officers' at Waikeria Prison on January 9, 2011 (2012, n.p.).

Nicholas was remanded at Waikeria on January 7, 2011, two days prior to his death. From the beginning and throughout the findings, Coroner Ryan (2012b) describes Nicholas's behaviour while on remand as 'abusive' (paras. 9, 52, 72), 'aggressive' (paras. 9, 10, 10, 21, 28, 34, 52, 72, 74), 'threatening' (paras. 13, 26, 52, 72, 74), or acting 'violently' (paras. 16, 31, 41, 42, 53). Nicholas was originally placed in the ARU and then transferred later the same day to the remand unit of the prison. He was then transferred to the separates, or punishment, unit on January 8 , following an incident in the remand unit.

According to evidence from Corrections officers, on the morning of February 9, Nicholas told officers he would hang himself and placed a noose around his neck. By the time more officers arrived, Nicholas had taken off the noose and was 'walking around his cell' (Ryan 2012b, para. 15). Approximately half an hour later, Nicholas sat down in front of the door to his cell and an officer reportedly deemed that he was attempting to hang himself. As a result, five or six officers rushed into his cell and immediately attempted to restrain Nicholas, face down on the ground. At all times, there were at least 6 officers restraining him, with additional officers replacing the initial restrainers as they became exhausted. 'All of the officers who gave 
evidence were consistent that Mr Harris was struggling violently during this five minute period' (Ryan 2012b, para. 42). After five minutes, Nicholas stopped 'struggling'. As a result, officers stopped restraining Nicolas, at which point he was unresponsive, being declared dead shortly thereafter.

One of the key issues at the inquest was the use of restraint on Nicholas. Corrections' 'National Coordinator for Control and Restraint and Advanced Control and Restraint', Wayne Le Haavre, gave evidence that there is a 'risk of a asphyxiation when a prisoner is being restrained, particularly while lying face down' (Ryan 2012b, para. 47). Le Haavre 'states categorically that, in his opinion, Mr Harris was not held face down any longer than was necessary for the officers to gain control. Mr Le Haavre gave his opinion that the control and restraint exercise carried out on Mr Harris was in accordance with the training and guidelines for such procedures' (Ryan 2012b, para. 47). A Corrections officer also gave evidence that he 'may have' applied body weight to Nicholas' back 'as the struggle grew progressively more serious' (Ryan 2012b, para. 49). While Coroner Ryan considers that the use of body weight 'contributed' to Nicholas' death, he nonetheless finds that the use of body weight was 'reasonable and even necessary' (2012b, para. 64).

Coroner Ryan ultimately determines 'from the evidence before me that this death occurred during a justifiable and necessary restraint of an aggressive, threatening and struggling prisoner, and that the restraint was carried out in accordance with the guidelines covering restraint procedures' (2012b, para. 74). These statements have some chilling implications. First, the coroner accepts Le Haavre's evidence that the restraint followed guidelines. This means that Corrections and the coroner accept that the application of Corrections policy can 
cause the death of a prisoner, without that policy being questioned. Second, the coroner describes the method of restraint as justifiable, reasonable and necessary. As the restraint is what led to Nicholas' death, the coroner effectively finds that Nicholas' death was justifiable, reasonable and necessary.

However, Coroner Ryan appears to apportion much of the blame on the victim. 'What was abnormal about this case is that Mr Harris resisted as the officers tried to restrain him' (2012b, para. 44 , emphasis added). For the coroner, the abnormality of this case is not the death of a prisoner but that person's 'resistance' as six guards restrained him face down on the ground. This leads him to the conclusion that the 'cause of death was asphyxia of an undetermined cause, initiated either by self-strangulation or a pre-existing medical condition, but in combination with restraint, with an underlying condition of morbid obesity with secondary dilated cardiomyopathy' (Ryan 2012b, para. 79).

Nicholas' family did not accept this account of his death.

The family are of the view that Mr Harris was not resisting the officers when they entered the cell and attempted to restrain him. In their opinion, Mr Harris was fighting for his life - not against the officers, but because he suddenly found himself struggling to breathe. (Ryan 2012b, para. 53)

The coroner rejects this submission, reasoning that 'If Mr Harris had suddenly found himself struggling to breathe to the point where he collapsed on the floor, in my view it is more likely 
that he would indicate his distress to any person near him rather than struggle violently, which would consume more oxygen' (Ryan 2012b, para. 53).

Coroner Ryan also accepts that the evidence provided by the Officers could be 'self-serving' (2012b, para. 61). However, he had 'no reason to doubt their integrity' (para. 61), even though he was eager to doubt Nicholas'. What this case, therefore, represents is a coroner's decision to accept the state's account of how it killed a person in its care. Coroner Evans consequently does not believe that any recommendations are necessary to prevent another reasonable, justifiable and necessary death.

This case exposes multiple conflicts, as well as whose interests the coroners serve. Where there is conflicting evidence between Corrections and the family, the coroner prefers Corrections' evidence. The conflict between the right to life and the supremacy of security facilitated Nicholas' death. The material practices that led to Nicholas' death, the sanctioned policy of restraint, are a part of the routine practices of imprisonment that validate prisoner's dehumanisation. Where the maintenance of the security of the prison is paramount, bodies that are not quite human get exposed to heightened insecurity. Where those bodies pose too much of a risk, the bodies are justifiably placed in social conditions, consisting of material practices that undermine their liveability. In such conditions, the death of the prisoner is reasonable, if not necessary. 


\section{Grieving the Death of the Prisoner}

Norms determining whether a life will be grievable are enacted on the body prior to its death. For Butler, whether a life will be grievable is determined by whether there is a presupposition that 'this will be a life that will have been lived' $(2010,15)$. In other words, for a life to be grievable, it must be treated in a way that demonstrates it is a life worthy of living, while alive. Lives that are unworthy of life are those that are not quite human, which come under constant threat from practices of dehumanisation that reproduce the worthlessness of the life. 'An ungrievable life is one that cannot be mourned because it has never lived, that is, it has never counted as a life at all' (Butler 2010, 38). For a life to count as a life, the social conditions in which it is embedded must support that life. Where those social conditions are failing, where the body is placed in highly precarious zones of abjection and dehumanisation, that life will not count as a life. Already ready for death, the loss of such a life is ungrievable.

The practices inflicted on the bodies of the people who have died in prison demonstrates a fundamental lack of support for the lives of those who died. The wider normative setting casts these bodies into prisons for being found to have, or alleged to have, breached normative standards of behaviour. When these bodies find themselves in prison, they are interpellated as bodies worthy of dehumanisation. Their ill-treatment is necessitated through the supremacy of the ideology of security. As an already-vulnerable population, the dependency on their captors to create conditions to support their lives heightens their vulnerability. As bodies worthy of being cast out, their fundamental precariousness prepares them to be placed in heightened precarity, often lacking conditions that sustain life. The bodies of the deceased matter, in the sense that they are physically made up of matter that can be supported or 
destroyed. However, the bodies simultaneously do not matter, as they are bodies that are cast out from normative regimes and are not countable as bodies that matter.

'Ungrievable lives are those that cannot be lost, and cannot be destroyed, because they already inhabit a lost and destroyed zone' (Butler 2010, xix). For the life of the inhabitants of this abject zone, their destruction 'might even seem like a kind of redundancy, or a way of simply ratifying a prior truth' (Butler 2010, xix). The death of the prisoner, often premature, preventable and in dehumanising conditions, merely affirms a 'truth' - the 'truth' that prisoners are worthy of dehumanisation.

In such a way, prisoners occupy a zombie-space of being living-undead. Their lives cannot be lost, because they are not materially supported as lives to be lost. Razack argues that both in and out of prison, 'Aboriginal people are often considered to be beyond help. They are, in this sense, already dead' $(2011,1)$. Razack thus echoes Butler's sentiment that, in a normative regime that requires the abjection of some bodies as its founding repudiation, the loss of those bodies is a loss of what could not be lost. It is the death of what was already dead.

Of course, the prison does not exist in isolation. The prison exists in a settler-colonial capitalist context that requires, as its founding repudiation, the destruction of tikanga and Māori ways of life, as well as the alienation of Māori from the land and the creation of a proletarian class. Material practices enacting the normative standards of settler-colonial capitalism create an underclass of people who are disproportionately Māori. Living in abject zones that exceed the prison, members of this underclass' lives are already exposed to heightened precarity and are, 
in this way, already ungrievable. Thus, the ungrievability of the prisoner is a part of a wider normative regime that denies conditions of worthy life to an underclass.

Of course, there are people who will grieve the loss of their friends and loved-ones in prison. This is demonstrated by countless families and friends who refuse to accept the way a prisoner was treated in the lead up to their death, or the way they were portrayed by state officials. For Butler, this grief takes 'place within the shadow-life of the public, occasionally breaking out and contesting those schemes by which they are devalued by asserting their collective value' (2015a, 197). This grief enacts the contradiction between the normative regime that denied the liveability of the life that died and an alternative logic which stresses that this was a life worthy of protection and sustenance.

In some of the findings, the prisoners see themselves as ungrievable or unworthy of life. A prisoner who took his own life wrote on the walls of his cell: 'three whom love me shouldn't ... if it makes you happy ... why are you so sad ... one less bad in the world' (McDowell 2009, para. 17, ellipses original). The prisoner here accepts that he is a 'bad', someone who does not deserve life. He believes he is undeserving of love and that those who love him should not be saddened by his death. At the same time, he recognises that those who love him will be sad, that they will have to grieve his death. He, however, rejects the need for that sadness because his life was a bad one, unworthy of grief. 


\section{Compassion}

Within this normative context that denies the grievability of prisoners, the coroners nonetheless demonstrate the state's attempt to grapple with the death. Some of the findings attempt to establish the compassion that was provided to the deceased in their dying days. Of the people who died of natural causes, a substantial number were ill for a long time prior to their deaths and were expected to die in prison. However, only in a minority of those cases was compassionate release mentioned. Compassionate release, as relevant here, occurs when a person is released from prison early because they are 'seriously ill and unlikely to recover', according to s 41(1)(b) of the Parole Act 2002. In a response to my Official Information Act request, Corrections states that between July 1, 2007 and June 30, 2016, there were a total of 32 people released on compassionate grounds, an average of 3.56 per year (Leota 2017b). ${ }^{49}$

Where compassionate release is mentioned in coroners' findings, it tends to demonstrate a lack of compassion showed to the deceased. Phat Vongphakdy was diagnosed with terminal liver cancer approximately two months prior to his death at Auckland Prison in 2008. Coroner Greig repeats Inspector Reese's finding that an 'application for compassionate release in accordance with the Parole Act 2002 section 41(b) was initially considered by prison management, but not progressed because of lack of understanding regarding roles and responsibilities' on Corrections' behalf (Greig 2010, para. 21). This lack of understanding meant that Phat was housed in a room in the Auckland Prison Health Centre, where he received pain relief that was not suitable for someone with a terminal illness and that 'was not given regularly' (Greig 2010, para. 18). In other words, Phat was quite possibly in

\footnotetext{
49 This compares to a total of 87 people who died of natural causes in the same period, an average of 9.67 per year, many of whom suffered from long-term terminal illnesses in the lead up to their deaths (Kelly 2017a).
} 
considerable pain when he died because of his imprisonment and the conditions of care in prison. Coroner Greig, however, agreed with the Inspector's finding that Phat received 'compassionate care ' (Greig 2010, para. 25).

In the case of David White, compassionate release was considered but an application was not made because David did not have anyone outside prison to support his application (na Nagara 2011a). David was increasingly ill in the months leading up to his death and appeared before the Parole Board multiple times before his death. The Board declined his applications, considering David a re-offending risk. Other than a two-year respite, David had been in prison continuously since 1987, which speaks to the Parole Board's opinion of the 'correctional' nature of prisons if a person is still a reoffending risk after 31 years in prison.

The case of Donald Liddington is notable for the fact that Coroner Scott (2016a) does not mention compassionate release throughout the findings. For nearly three years prior to his death in 2015, Donald was held in the High Dependency Unit at Rimutaka Prison. ${ }^{50}$ At that time, his 'death was expected. It was a matter of when, not if' (Scott 2016a, para. 5). Coroner Scott, nonetheless comments, that a 'society is often judged according to how it reacts to and treats its most vulnerable members and at the time of his death Donald was certainly one of these people. I am pleased to record that so far as I can determine he was well cared for and treated during his last days with kindness and compassion' (2016a, para. 12). Although Coroner Scott may believe that it is compassionate to imprison a dying person, the failure to

\footnotetext{
${ }^{50}$ The High Dependency Unit at Rimutaka Prison is used 'to house prisoners with health issues that make it difficult for them to function independently, but who are not eligible for release' (Department of Corrections 2016c, 8).
} 
consider whether Donald could be released to die in the community demonstrates a contradictory lack of compassion.

\section{The families}

The families of the deceased are, in many cases, the human faces to which coroners are required to express their impossible grief. Coroners, in their findings often say something to the effect of 'I extend my sincere condolences to Mr Kahu's family on their loss' (na Nagara 2008, para. 82). Coroners extend condolences in $60.19 \%(n=65)$ of cases overall, $60.61 \%(n$ $=40)$ of natural deaths, and $60 \%(n=24)$ of unnatural deaths.

However, these condolences, although not always expressed, obscure the conflicting interests and narratives of the families and the state. Families often reject the official account of the deceased's death. As noted above, in the case of Nicholas Ward Harris, who died while being restrained by Corrections officers, Coroner Ryan comments that although the evidence from the Corrections officers involved may be 'self-serving', he has 'no reason to doubt their integrity' (2012b, para. 61). The family in this case strongly dispute the coroner's account of Nicholas' death. ${ }^{51}$ In the findings, Coroner Ryan notes multiple factual disputes the family had with Corrections' evidence, but prefers Corrections' evidence in all instances. It was also reported in the Waikato Times, a daily regional paper, that Nicholas' brother-in-law interrupted evidence provided by Detective Sergeant Ross Patterson. Waikato Times quotes

\footnotetext{
${ }^{51}$ The family established a public Facebook page in honour of Nicholas here: ('In Honour of Nicholas Ward Harris' 2017)
} 
Nicholas' brother-in-law as saying: 'The first call we got was that he committed suicide. You're f...... murderers, that's what you are' (Kidd 2012, n.p., expletive deleted in original).

Similarly, the extension of condolences contradicts the vilification of the deceased in many of the cases. When a coroner's finding interpellates a deceased as an 'offender' or a bad person, the subject being interpellated, the deceased, exceeds the coroner's interpellation. Interpellation is a continuous process of being addressed that is open to misaddress and refusal. 'Interpellation is an address that regularly misses its mark' (Butler 1997a, 33). In this way, the families of the deceased may contest the disreputable figure of the deceased constructed at an inquest. Thus, the vilification of the deceased can be a point of conflict between the state and the family's account of the deceased. In a case analysed by Scraton and Chadwick, the reputation constructed by officials was rejected by the families of the deceased, with one family member saying about the depiction of their loved-one that 'that was someone they created for their own purposes... they slandered good people. It was a travesty' (quoted in Scraton and Chadwick 1986, 103, ellipsis original). ${ }^{52}$

The conflict between the interests of the families and the state is demonstrated through differences in mean word count of the coroners' findings, depending on several factors.

\footnotetext{
52 As I have not conducted interviews for this thesis, I do not have any similar statements from families in the cases I have. Although families clearly contest evidence presented at the inquests, it is unclear from the findings whether that contestation extends to the vilification of the deceased.
} 
Table 15: Mean word count of coroners' findings into deaths in prison

\begin{tabular}{|l|l|l|}
\hline Category & Mean & Count \\
\hline All & 3684.65 & 107 \\
\hline Natural & 1727.87 & 66 \\
\hline Unnatural & 6962.28 & 40 \\
\hline Self-inflicted & 6089.81 & 37 \\
\hline Men's Prison & 3518.17 & 102 \\
\hline Women's Prison & 7081.00 & 5 \\
\hline Section 74 case & Censored & 1 \\
\hline
\end{tabular}

As seen in Table 15, the mean number of words of all findings was 3684.65 . The mean for natural deaths is approximately half that (1727.87), and nearly double for unnatural (6962.28) and self-inflicted (6089.81) deaths. Findings into deaths in women's prisons (7081) have a mean word length more than twice the size of men's prisons (3518.17), despite $80 \%$ of cases into deaths in women's prisons being natural deaths.

I further collated information on whether a family counsel or a representative of the Howard League for Penal Reform was mentioned. A family lawyer was mentioned in $12.04 \%$ of cases $(n=13)$, a Howard League representative in $10.19 \%$ of cases $(n=11)$, and both in $5.56 \%$ of cases $(n=6)$. It is important to note, however, that a family lawyer or League representative may have been present at an inquest but not mentioned by the coroner. Further, the Howard League only had representatives in cases of unnatural death, which may also inflate its mean word count.

As seen in Table 16, the mean word count is approximately 4 times higher than the overall mean (3684.65) when either a family lawyer (10626.92) or Howard League representative (11736.27) is mentioned. Where both a family lawyer and a Howard League representative 
are mentioned, the mean word count is 15691.33 , which is 4.26 times larger than the overall mean (3684.65), and 6.31 times larger than cases where neither is mentioned (2484.91).

Table 16: Mean word counts for findings based on family counsel and Howard League mentions

\begin{tabular}{|l|l|l|}
\hline Category & Mean & Count \\
\hline Family Lawyer & 10626.92 & 13 \\
\hline Howard League & 11736.27 & 11 \\
\hline No Family & 2724.56 & 94 \\
\hline No Howard & 2762.07 & 96 \\
\hline No family or Howard & 2484.91 & 101 \\
\hline Family and Howard & 15691.33 & 6 \\
\hline Section 74 case & Censored & 1 \\
\hline
\end{tabular}

Although it is not possible to definitively determine the effect of family lawyers and Howard League representatives on the contents of findings, it seems, from this data, that coroners are at least required to note a wider range of circumstances, and reflect this in the word length, where there is some kind of representation. Where families of the deceased do not have representation, the findings are shorter and Corrections' evidence may remain unquestioned. This betrays the ideological purposes of the coroners' findings. It seems that, unless they are pushed to consider a greater range of evidence, coroners are content with shorter findings, largely based on Corrections' evidence.

In $12.96 \%$ of cases $(n=14)$, the coroner mentions the fact that the family disputes some part of the Corrections' evidence. In $100 \%$ of cases where that dispute is noted $(n=14)$, the coroner prefers the evidence of Corrections over the family. In saying that, there may be other instances where there has been a disagreement between Corrections and the family, and where the coroner has not noted it in the findings, regardless of whose evidence they preferred. What this says, nonetheless, is that although the inquests and inquiries are sites of conflict between the state and the families, the Coroners Court, as an arm of the state, invariably prefers its own 
evidence. While the families may be able to force the coroner to consider more circumstances of the death, the coroner is, in cases of custodial death, ultimately the way that the state attempts to justify the death of a person in its care.

\section{On policy and practice}

Given the broader dehumanising conditions that prisoners experience in New Zealand prisons, it is telling that coroners are largely concerned with small-scale policy failures in the lead up to the death. These small-scale failures often include the length of time it took to open the deceased's cell, the presence of hanging points, and cell location checks. As a counsel to the Department of Corrections states in a case of self-inflicted death, 'Every one of these incidents is carefully examined and where appropriate, changes are made to our policies, practices and procedures to reduce the potential risk of future incidents' (Corrections' counsel quoted in Devonport 2015a, para. 53). This kind of reform is the only thinkable response from Corrections, where the prison itself increases the suicidality (National Health Committee 2010; Shalev 2017) and norms of dehumanisation are inherent to the prison.

One day prior to her death from natural causes at Auckland Regional Women's Corrections Facility (ARWCF), Anna Kingi asked a nurse if she could see a doctor (Greig 2012a). The nurse made an appointment for her the next day, which was subsequently cancelled because of understaffing. At around 9:30pm on the evening of her death, Anna raised her cell alarm to indicate that she was experiencing distress. This alarm was an intercom system, to which Master Control took four minutes to respond. This four-minute delay occurred because the 
Corrections officer in Anna's unit did not bother to forward the cell alarm calls to Master Control when she was not in the unit office.

When the Corrections officer at Master Control answered the cell intercom, she asked 'what's your emergency' twice, and did not get a response from Anna (Greig 2012a, para. 62). As a result, the Corrections officer cancelled the cell alarm. This was in breach of policy because Anna was required to be checked following the activation of her alarm. At 10:55pm that evening, another Corrections officer, who was conducting a routine cell check, found Anna on the floor of her cell, unresponsive. It then took thirteen minutes for Anna's cell to be unlocked as the only key to the cell was held on the far side of the prison grounds. By that time, Anna had died.

Coroner Greig (2012a) is highly critical of several small-scale policy failures at ARWCF. Coroner Greig criticises the fact that more regular cell location checks were not conducted and that the officer in Anna's unit manipulated monitoring systems to make it appear that she conducted more cell checks than she had. She further criticises the officer at Master Control's decision to cancel the cell alarm, commenting that 'it is difficult to understand why Ms Fononga felt that it was acceptable to take no action when Ms Kingi did not respond to her two specific queries as to what her emergency was' (Greig 2012a, para. 62). Coroner Greig is 'critical that the arrangements are such at ARWCF that it required thirteen minutes to get Ms Kingi's cell unlocked' and that 'prison management has considered such a response time "to be the way it is"' (2012a, para. 73). 
Ultimately, the coroner concludes that Anna 'was let down by the environment at ARWCF on the night of her death. There were poor prison systems as well as individual staff who were found wanting on the night' (Greig 2012a, para. 88). Of the cases I have, Anna's case is the only case where a coroner is willing to explicitly label the environmental conditions of imprisonment as a circumstance of the death. However, the environmental issues that Coroner Greig highlights, including the time taken to unlock the cell, were either necessary for security reasons or normative practice which presupposed the inhumanity of prisoners. The environmental issues are also attributed to specific policy failures and failures of individual staff members, rather than the normative structure of imprisonment. Even in this rare case where the coroner explicitly attempts to understand the environmental circumstances in which the prisoner died, the coroner's failure to grapple with that death as a structural issue of imprisonment means that she could not fully account for the death.

A policy failure that is often noted by coroners in findings of self-inflicted death is the presence of hanging points within cells. In Glenn Mills' case, Coroner Greig says 'I have become aware during the course of this inquiry that there were a total of fourteen suicide deaths at MEMP from 1 October 1996 to 1 October 2011 (excluding the death of Mr Mills). Of these, ten of the deaths occurred in circumstances where prisoners utilised the bars inside the cell window as the hanging point' (2012b, para. 48). Similarly, Coroner Devonport (2012a) comments that one type of hanging point was used in multiple self-inflicted deaths at Christchurch Men's prison.

Corrections consistently responds to coroners' concerns about hanging points with comments such as, 'All "ligature points" in mainstream cells (including Directed Segregation Cells, but 
excluding cells in the At Risk Unit) cannot be removed without creating a sterile and inhumane living environment for prisoners' (Devonport 2015a, para. 53). Almost this exact phrase is presented in several cases as the opinion of the coroner, rather than a quotation from Corrections (Devonport 2010a; Greig 2012b; Scott 2012c). Another phrase which usually accompanies the impossibility of removing all hanging points is that 'the Department of Corrections has adopted the approach that robust upfront assessment and then having good strategies for managing people while they are deemed at risk is better than just reducing hanging points in prisoner cells' (Greig 2012b, para. 52).

Coroner Scott's comments on this topic highlight some important underlying assumptions in these phrases. For Coroner Scott, 'Obviously total "risk-proofing" is impossible and/or it would make an inmate's life intolerable. In fact, it might even increase the likelihood of suicides amongst low-risk inmates in that it would make the low/medium-risk cell environment so uncomfortable and un-user friendly as to cause depression' (2012a, para. 21). However, 'risk-proofed' cells, which would, according to the coroners, be inhumane and possibly increase the suicidality of prisoners, exist in New Zealand prisons. They are in the At-Risk Units. What this line of reasoning from the coroners suggests is that where suicide deaths can be attributable to the policy failures, the rectification of those failures necessarily requires the further dehumanisation and possible exacerbation of suicidality of at-risk prisoners.

In those instances where the coroner does not merely accept that Corrections will do better, they make recommendations. Under the Coroners Act 2006 section 57A(2), recommendations 'may be made only for the purpose of reducing the chances of further deaths occurring in 
circumstances similar to those in which the death occurred'. The coroners make recommendations in only $23.15 \%$ of the cases $\mathrm{I}$ have $(\mathrm{n}=25)$. The coroners make recommendations in $40.57 \%$ of cases of self-inflicted death $(n=15)$ and $13.64 \%$ of natural deaths $(n=9)$. Where the coroner makes a recommendation, the mean number of recommendations is 2.68 .

Coroners' recommendations fail to grapple with custodial deaths. In not a single instance in the cases I have did a coroner recommend anything other than a small-scale policy reform. Remarkably, in the death of Jai Davis, who died from a drug overdose while being housed in extreme isolation, Coroner Crerar (2015) makes two recommendations: that Corrections replicate the Police's policy on dealing with people suspected of internally concealing drugs, and the Police consider making a new email address for intelligence-gathering purposes. Neither of these recommendations address the dehumanising practices in ARUs or the supremacy of security over care in New Zealand prisons.

In other cases, recommended reforms include eliminating hanging points (McDowell 2009; Devonport 2010b; Scott 2012c; Devonport 2015a), increasing the regularity of cell-checks (Crerar 2011; Ryan 2012a; McElrea 2012), having additional at-risk screening (McDowell 2014), changes to at-risk screening mechanisms (McElrea 2012; Scott 2012c; Evans 2013), improving times for opening a cell in response to a crisis (Devonport 2011; Greig 2012a; Evans 2013), and improving responses to cell alarms (Greig 2012a). The banality and bureaucratic repetitiveness of these recommendations reflects the banality and repetitiveness of the deaths. 'It assumes that people who choke on their own vomit, hang themselves in a distressed state or die unattended in a police cell are not controversial so long as they are 
checked every half-hour' (Scraton and Chadwick 1986, 101). For Razack, the worthlessness of Indigenous lives is

papered over in inquests and inquiries with recommendations proposing that state actors develop greater cultural sensitivity, remember to check cameras in police stations and hanging points in cells, create protocols for dealing with alcoholics, and learn to take better care of Indigenous prisoners in hospitals and jail cells. Oftrepeated, the recommendations indirectly confirm that settler society finds it difficult to provide the barest minimum of care and respect to a population it over-polices and incarcerates at rates that are among the highest in the Western world (Razack 2015, 194)

Similarly, the often-repeated recommendations in these cases work to reproduce the inevitability of these deaths in prison by failing to see past banal bureaucratic problems in individual cases.

However, the cases where coroners do not make recommendations suggest an even greater resignation to the inevitability of preventable custodial deaths. In $59.46 \%$ of self-inflicted deaths $(\mathrm{n}=22)$ and $75.93 \%$ of all cases $(\mathrm{n}=82)$, coroners do not make any recommendations. The failure to make a recommendation suggests that the coroner is unconvinced any changes could be made to prevent similar deaths. The lack of recommendations is particularly noticeable in the death of Nicholas Harris, who died while being restrained by Corrections officers. As noted, the coroner, in agreement with Corrections officials, finds that Nicholas' death followed what was a reasonable, justifiable and necessary use of restraint. Coroner Ryan states that he is 'confident that, if there are any other learnings to be gleaned by the Department 
of Corrections from this very unfortunate death, then that department will take cognizance of those learnings and will consider whether such systems or procedures can be improved' (2012b, para. 83).

This confidence in Corrections' ability to prevent custodial deaths is shared across the findings, both implicitly and explicitly. This confidence, as well as recommendations that repeat smallscale policy changes as the solution to these deaths, demonstrates that the state is not willing to recognise that the conditions of imprisonment are not life-affirming. In making recommendations that merely tinker around the core issues of dehumanisation, or by failing to make recommendations at all, coroners accept the normality of custodial deaths, as a byproduct of incarceration.

\section{Discourses of individualism}

Almost all the language around the circumstances of self-inflicted deaths refers to the deceased's 'choice' or 'decision' to take their lives. Commenting broadly, Coroner Devonport says that because 'suicide is a choice, no one, including family, Corrections Staff, or clinicians, could exert full control over [the deceased]'s choice to live or die' (2015b, para. 34, emphasis added). In other words, coroners often assume an individual stands behind the decision to take one's own life in prison.

The presupposition of individualism is accompanied by an implicit rejection of structural factors as causes of custodial death. In the case of Tony Worrell, environmental factors were explicitly excluded from consideration. In that case, Peter Williams QC, on behalf of the 
Howard League submitted that appalling environmental conditions were a major contributor to Tony's death. 'As examples of the "appalling” circumstances of Mr Worrell's incarceration Mr Williams referred to Mr Worrell having his meal in his cell next to a toilet three times a day, a lack of encouragement to become involved in matters that would have taken his mind off his problems, and his obvious loneliness with a paucity of visitors' (McDowell 2014, para. 106). Coroner McDowell, however, concludes in a mocking tone that 'there is no evidence of an "appalling" prison environment which specifically contributed to his death' (2014, para. 107). This statement is exemplary of the fact that the coroners' focus is largely limited to individual events in the lead up to the death.

It is in this context of 'individual' problems that the vilification of 'individual' prisoners is an essential part of the state's account for the death. The state ultimately uses the abjection of the prisoner to justify their death. Scraton and Chadwick argue that the officials often employ the vilified reputation of the deceased, as a 'negative reputation is established and developed which suggests that they - the people who have died - are the problem. It is as if their actions have contributed to their deaths' $(1986,101)$. In other words, it is the deceased, a bad or broken person, rather than the state, who is ultimately responsible for their death.

It is notable that coroners outline the offending of the deceased in $81.08 \%$ of self-inflicted deaths compared to $51.52 \%$ of natural deaths. Recalling that the detailing of a deceased's history of offending interpellates the deceased as a bad person worthy of imprisonment, the disproportionate vilification of the deceased in self-inflicted cases demonstrates the coroners' use of the vilification to implicitly justify the preventable death. Instead of holding the state to account for the conditions contributing to or inducing suicidality, the construction of the 
deceased as a bad person makes their death justifiable. It is, in these cases, the death of someone who was worthy of death.

Coroner Crerar (2015) adopts this narrative in Jai Davis' case. Jai was held in dehumanising conditions in the lead up to his death. The coroner finds that he died of an overdose from drugs he was concealing in his rectum. He was provided poor medical care and it appears that he was unable to hand over the drugs without repercussions. As a result, Jai started consuming the drugs to avoid further punishment and died from doing so. Although the coroner is critical of Corrections officials' actions, he also details Jai's criminal history and his alleged drugdealing. Jai was a 'criminal' and, as such, 'the person most responsible for the circumstances which led to his death' (Crerar 2015, para. 48).

Further, the coronial categorisation of 'self-inflicted' deaths reproduces individualising notions that the death was an individual's choice or the result of a defect with them as an individual. Scraton and Moore argue there is often an assumption from state officials dealing with incarcerated people with suicidal ideation that 'suicide is driven by an individual's pathological condition; a force so powerful that it defies prevention' $(2005,95)$. It is assumed that these people are broken or uncontrollable and, because of their individual frailty, their death is inevitable.

The language of 'self-inflicted' death itself, which is the only way the Coroners Act 2006 allows me to speak about many of these deaths, reinforces the idea that the death was 'an unfortunate but inevitable consequence of individual pathology' (Scraton 2016, 6). These 
individualising discourses presuppose a liberal ontology of an atomistic individual who acts independently within their social conditions. The bodily ontology constructed throughout this thesis, alongside Butler, notes the inherent sociality of the body. The body is always produced and sustained by social conditions that exceed it. The body can never be reduced to a discrete individual, as it is constituted by and dependent on language, norms, and material lifesustaining conditions. As such, a 'self-inflicted' death is an impossibility. The death, while produced by the body that died, occurs in social conditions that enabled the death. Thus, despite the effort to reduce 'self-inflicted' deaths to individual pathologies, such a reduction denies the sociality of the death.

As with all texts, there are multiple contradictory discourses in the coroners' findings. Although the coroners presuppose an atomistic individual who is, in the final instance, responsible for their own death, the narrative that individuals cause their own death breaks down in many of the findings.

While focussing on the thoughts or feelings of individuals in their lead up to their self-inflicted death, the discussion of these thoughts and feelings exposes the sociality of their position. Coroner Scott outlines how Donald Gisborne made 'his final decision' (2012b, para. 32) to end his own life. This 'decision' was, however, 'influenced' by 'Firstly, his failure to come to terms with his offending; Secondly, the lack of any outside prison support; Thirdly, that it was his first term of imprisonment; Fourthly, his age and his prospects of a release from prison within his lifetime were against him' (2012b, para. 32). In other words, in pointing to the individuality of the 'decision' to take his own life, Coroner Scott notes the sociality of that 
'decision'. Donald was not making it alone but along with social conditions that made his life unbearable to live.

In other cases, there is evidence such as a letter that the deceased wrote explaining their feelings at the time they died. Most of these instances are either censored by sections 71 or 74 of the Coroners Act. In a case that is not censored, Coroner Greig paraphrases a letter saying that 'after six months in custody he could bear it no more and would rather be dead' $(2012 \mathrm{~b}$, para. 41). In other instances, it appears that the deceased felt an overwhelming sense of shame and disappointment from their loved-ones for ending up in prison.

The fact of being sent to prison was overwhelming for some of the deceased. A person who died one day after being remanded in custody told a police officer prior to being remanded what he thought about the prospect of returning to prison. He told the officer 'he is sick of upsetting everybody around him and has nothing to live for. He states that if he gets locked up or if his girlfriend leaves him he will kill himself' (Devonport 2010b, para. 8). Another person died apparently believing that his actions that led him to prison were unforgivable. He 'did not accept that he could be forgiven by the victim's family', experiencing 'compounded feelings of hopelessness' (Bird quoted in na Nagara 2011c, para. 43). In this way, the deceased's relationship to the institution of the prison and its social meaning, as well as the social impact of the deceased's behaviour, expose the sociality of how they were feeling.

Other people clearly feared for their safety while in prison. Bradley Twidle, who took his own life in Christchurch Men's Prison, was held in the same prison as two men who had been 
convicted of sexually assaulting him. Bradley read out a victim impact statement in Court about the men approximately a month prior to his death. Although prison management separated Bradley from these men, evidence suggests that the men were nonetheless able to communicate with him, with one allegedly threatening him that 'you'll get what's coming to you' (Devonport 2015a, para. 23).

In the case of Richard Barriball, Coroner Crerar states that Richard, whose arm was broken shortly before his imprisonment, 'suffered from an underlying fear that he would be the victim of a prison assault, his fear being exacerbated by the fact that his injury meant that he could not appropriately defend himself' (2012a, 67). The then- Acting Assistant Regional Manager Jack Harrison dismissed this fear as delusional. Manager Harrison reasoned that Otago Corrections Facility (OCF) was safe and that Richard was not at risk of assault 'because he was in a remand facility' (Crerar 2012a, para. 46). 'Manager Harrison stated that, in his opinion, the concerns about his personal safety expressed by Richard Barriball were more perceived than real. In the more than eight years since Richard Barriball was last in prison, Corrections have created an environment "where everyone feels safe", (Crerar 2012a, para. 47).

Although Manager Harrison may have believed this, evidence from the Office of the Ombudsman suggests this is a highly inaccurate assessment. In its 2016 report into OCF, the Ombudsman finds that $32 \%$ of survey respondents stated they had been assaulted while at OCF, $45 \%$ had felt unsafe at OCF, and 7\% claimed they had been sexually assaulted in prison (Boshier 2016c). Other reports suggest that people on remand are the most likely to experience 
violence (Boshier 2016a, 2017b). Of course, this heightened fear and experience of violence is a result of social conditions that expose the body to greater violence.

Coroners also note that the prospect of a long sentence of imprisonment may also have weighed on the minds of the deceased. Coroner Scott comments, 'I can of course state the obvious, that a prison is unlikely to be a particularly happy place for someone in [the deceased's $]^{53}$ situation who was facing a long sentence. That is why he may have chosen to end his life' (2012a, para. 18). Implicit in this assumption is that a prison sentence, let alone a long sentence, is unbearable, with even the prospect of it being life-destroying.

However, coroners often attempt to reinforce the individual circumstances of the death, almost always finding self-inflicted deaths to be the fault of the deceased. In Zachariah Tangohau's case, Coroner Devonport criticises the deceased for not alerting Corrections to his feelings. 'Mr Tangohau did not seek assistance, despite the fact that written notes he made which were located after his death indicated that he was troubled and had been so troubled for a period of possibly four months' (Devonport 2012a, para. 36). For the coroner, if Zachariah had only done what the coroner deemed to be reasonable, he would be alive.

Reading across the findings, the individualising discourse that the coroners adopt is a part of the state's attempt to deny its responsibility for the death of a person in its custody. This discourse, however, necessarily breaks down, exposing the sociality of the bodies that take their own lives. In this way, the coroners' attempts to deny the responsibility of the state in

53 The name of this person was censored under $\S 74$ of the Coroners Act 2006. 
preventable custodial deaths fail, as their findings simultaneously expose the conditions in which the death occurred. These conditions, produced by the state, make the death of the prisoner a collective death, as well as the responsibility of the state.

\section{Purpose of coroners' inquests and inquiries}

In many cases, the coroner simply accepts that the death was unpredictable and nothing could have been done to stop it. For example, Coroner na Nagara states that Taffy Hotene 'gave no indication to other prisoners or prison staff of what he intended to do. Accordingly, I do not consider it could have been anticipated, and I do not consider that there was anything anyone could have done to prevent it' (2011c, para. 74). Implicit in these findings is that Taffy's individual suicidal ideation, and his failure to disclose it, effectively recuses the state of any responsibility for his death.

Similarly, in Zachariah Tangohau's death, Coroner Devonport comments that if 'Corrections staff do not observe changes in a prisoner's behaviour that would warrant a risk assessment review, or if a prisoner does not seek assistance, there remains the possibility that prisoners (such as occurred with Mr Tangohau who was troubled but did not display or disclose his issues) will slip through the gaps' (2012a, para. 115). In that statement, Coroner Devonport effectively argues that self-inflicted deaths in prisons can only be prevented by staff intervention and placing people with immediate suicidal ideation in ARUs. Finally, although the coroner finds that Kurt Graham's death was self-inflicted, Coroner Crerar nonetheless accepts that 'Everything that should have been done was done' (2011, para. 42). 
These kinds of statements indicate coroners' acceptance of the inevitability of self-inflicted deaths in prisons. Coroners Greig and McDowell use an identical phrase in two cases of prison suicide, that 'Obviously, the risk of suicide in prison can never be completely eliminated' (McDowell 2009, para. 39; Greig 2012b, para. 54, emphasis added). Similarly, Coroner McElrea comments that it 'is accepted that no system that allows prisoners a degree of normality in their living conditions will eliminate all self-inflicted deaths in custody' (2012, para. 75, emphasis added). The obviousness of the inevitability of suicide in prisons is thus accepted as a natural part of imprisonment.

Coroner Devonport also states that people 'in prison are known to be at a higher risk of suicide and self harm than the general population, and suicide is a common cause of death in prison' (2012a, para. 111), while Coroner Shortland quotes Prison Director Sherlock stating 'All prisoners by virtue of being in prison pose an increased risk of self-harming behaviour' (Sherlock quoted in Shortland 2016, para. 48). Coroners, however, fail to breakdown these assumptions, while the contradiction between the emphasis on individual agency and the prison being an environment of heightened rates self-harm is never resolved.

Accompanying the assumption that prisons are sites of increased risk of suicide, coroners often express their confidence that the problem of custodial death will be addressed. In David Crosland's case, Coroner Scott notes 'What went wrong and what should have been done are obvious and I am confident that Police and corrections [sic] will do their very best to see that there is no repetition in future. That is all that can be expected' (2016b, para. 34, emphasis added). This sentiment is shared by Coroner Ryan, who comments that 'I have confidence that 
the Department is sufficiently concerned to take whatever action is appropriate to reduce the number of suicides in prisons' (2012a, para. 30, emphasis added).

This confidence that everything will be done by Corrections to reduce future self-inflicted deaths also contradicts the assumption that prison suicides are inevitable and occur at a higher rate than in the community. However, for many coroners, the very purpose of coronial inquests into deaths in prisons is about confidence. Coroner Shortland comments that 'Any death in prison is one too many, which always casts suspicions and doubts on the system and individuals who work within it' (Shortland 2013, para. 101). While outlining the purpose of their inquests into deaths in prison, Coroners Greig (2012b, para. 90), McDowell (2009, para. 43), and Evans (2015, para. 55) ${ }^{54}$ state emphatically that it 'is important that the public should have confidence in the New Zealand prison system'. In other words, self-inflicted deaths in prison are inevitable and yet undermine confidence in the prison system. The purpose of coroners' inquests is thus to reaffirm confidence in the prison system by identifying small policy failures, where, if they are even present, should be avoided in the future. The Coroners Court, as an ideological state apparatus, is thus a tool for the maintenance of the prison system and confidence in it.

Given this purpose, and the wider conditions of imprisonment, the coroners effectively foreclose the possibility of the state grieving the death of the prisoner. At a normative level, the prisoner's life is ungrievable. It is ungrievable because it is normatively expelled from the meaning of human. The vilification of prisoners generally, and the deceased specifically,

\footnotetext{
${ }^{54}$ Evans' phrase is slightly different, referring to New Zealand's 'public prisons' system. This small difference in wording from Coroner Evans may be an expression of the coroner's personal opposition to private prisons.
} 
signals their construction as beings that are ready for maltreatment and death. The practices of dehumanisation in prisons validate their vilification and abjection, reproducing their inhumanity. Their vulnerability exposes them to heightened precariousness, being dependent on the institutions that dehumanise them for their own sustenance. In this way, prior to their death, prisoners inhabit a zone of abjection, where their bodies are constructed through the practices of imprisonment as bodies unworthy of support and not quite a life. Because these lives are not fully recognisable as lives, the loss of them is ungrievable according to the normative standards that deny their lives.

In this sense, although I can count the number of people who have died in prison, their ethnicity, gender, age, and prisoner type, I cannot make the lives of these people count. Within a normative framework that denies prisoners the social conditions of a life worthy of living, their death cannot count. Their lives are ungrievable.

The state itself is a fractured, contradictory, and incomplete subject that must come to terms with the loss of a person in its custody. While it attempts to mourn the loss of the prisoner, it cannot truly do so if it accepts the inevitability of preventable custodial death and the dehumanising social conditions of imprisonment. For Butler, 'one mourns when one accepts the fact that the loss one undergoes will be one that changes you, changes you possibly forever, and that mourning has to do with agreeing to undergo a transformation the full result of which you cannot know in advance' $(2004,18)$. The state and its prison system, however, remain constant in the face of the loss of a prisoner. 
When faced with the loss of a prisoner, the state is in a state of denial. The coroners' findings represent the state's refusal to fully accept the loss of the prisoner. Through the vilification of the deceased, the state demonstrates that the loss of the deceased was no loss at all and that their death is attributable to their failures as a person. By fixating on small-scale policy issues, the state fails to recognise how everyday practices of dehumanisation are inherent to imprisonment. The failure to address these dehumanising norms renders the state incapable of understanding the death of those subject to these norms.

Further, where coroners make recommendations in the hope of reducing future deaths, these recommendations deal only with the small-scale failures and not the broader structures of imprisonment. The individualising discourses that the coroners adopt, although often breaking down, remain an attempt by the state to apportion blame away from the institution and onto the failures or decisions of an individual. Finally, the state's acceptance that preventable deaths in prisons, particularly suicide deaths, are inevitable represents its unwillingness to see the prisoner's life as one worth preserving. It reaffirms the state's commitment to continue practices of dehumanisation that prepare the prisoner for death.

These trends within the coroners' reports are part of the state's broader inability to accept the loss of the prisoner and its role in creating the conditions for the loss. The loss of this abject being cannot be fully mourned by the state, as by accepting the inevitability of such losses, it refuses to be transformed by them. In that sense, to truly mourn the death of the prisoner, a material transformation in the social conditions that facilitate carceral death is required. In the conclusion of this thesis, I argue that to truly accept the death of the prisoner, the category of the prisoner must itself be abolished. 


\section{Conclusion}

Joan Baez's (1972) song 'Prison Trilogy (Billy Rose)' expresses a way in which to mourn the loss of the prisoner. Beginning with Billy Rose, she writes about how he was 'severely reprimanded' for fighting a prison officer for some milk. Billy then took his life in the early hours of the morning, in 'the blackest cell on "A" Block'. Luna, a Mexican immigrant who was separated from his wife and baby and thrown in jail, 'eased the pain inside him / With a needle in his arm / But the dope just crucified him / And he died to no one's great alarm.' Finally, she describes old Kilowatt being released from prison after 35 years. However, 'it seems a state retainer / Claims another 10 years of your life.' The effect of his long-term imprisonment means he is effectively condemned to social death - 'They might as well just have laid / That old man down'.

Baez does not demonstrate the possibility of mourning the prisoner by simply describing the biological or social death arising from their imprisonment. At first, Baez urges the listener to 'Come and lay, help us lay / Young Billy down', focusing on the individual instance of the prison death, rightfully grieving the loss of that person and laying them to rest. However, following the loss of Luna and Kilowatt, Baez's anger at the structural circumstances of the biological and social death leads to her attempt to grieve the loss of the prisoner by preventing the loss of another. After urging us to help lay Luna down, she declares 'And we'll raze, raze the prisons / To the ground'. It is in this necessary shift in focus from the single instance of death to the social conditions that enable it that Baez demonstrates how we can truly mourn the death of the prisoner: the abolition of prisons. 
Taking Coroner Scott's (2012c) assumption that prisons must necessarily dehumanise the prisoner to keep the public safe, as well as the assertion of the inevitability of self-inflicted deaths in prisons, there is a contradictory acceptance within the arm of the state tasked with minimising preventable deaths that those deaths, and the dehumanising circumstances in which they arise, cannot be eliminated. Consequently, coroners make recommendations that tinker around the edges of prison practices, sometimes even exacerbating dehumanising conditions. However, they can never recommend what is needed to prevent preventable prison death: the end of imprisonment.

This is despite damning evidence that demonstrates the inability of prisons to achieve their intended purpose of correcting harmful behaviour (P. Smith, Goggin, and Gendreau 2002; Rethinking Crime and Punishment 2015). People leave prisons more damaged and more likely to hurt others on their release (National Health Committee 2010). As McIntosh argues, 'incarceration is a collective experience. Prisoners come from families, they will return to families, and their imprisonment has a marked impact on their families' $(2012,440)$. The families and communities from which prisoners come experience the economic and social strains of having whānau in prison, sometimes having long-lasting effects (Gordon and MacGibbon 2011; Mlinac 2016).

As Reiman (2004) contends, the prisons' failure to reduce harm and 'correct' behaviour is a successful failure. The ultimate purpose of imprisonment is, in fact, achieved by imprisoning poor and indigenous people. This both ensures the undermining of indigenous and proletarian capacity for organising a transformation of settler-colonial capitalism, as well as the ideological 
reproduction of the necessity of the ruling class' hegemony, as expressed through the state and its 'protection' of the public.

This is, of course, a structural process that does not necessarily require the specific and intentional adoption by ruling class actors of carceral policies for the purposes of undermining proletarian and indigenous struggles. 'The unplanned and unintended overall result is a system that not only fails to really reduce crime but does so in a way that serves the interests of the rich and powerful' (Reiman 2004, 6). In the same way, the inability of the state to mourn the death of the prisoner is not the result of any coroners' malicious intent. Coroners often struggle to make sense of, and are at pains to express sympathies, to the families of those who die in prisons. What matters, however, are the structures of imprisonment that exceed any individual coroners' findings.

These structures of imprisonment, which expose prisoners to heightened vulnerability, dehumanisation and maltreatment, also make inevitable otherwise preventable deaths. And yet, the prison is so entrenched in the normative framework of settler-colonial capitalism that the possibility of truly addressing prison death is unthinkable. Reiterating Davis' contention that the "prison is considered so "natural" that it is extremely hard to imagine life without it" (2003, 10), the abolition of prisons is an impossibility in a normative regime that depends on the prison for its own reproduction.

Despite its normative impossibility, the abolition of prisons is also necessary in order to mourn the death of the prisoner. To take on the loss of the prisoner, to be transformed by it, and to 
prevent its reoccurrence, the conditions that lay the groundwork for the loss must be addressed. If the social conditions of imprisonment are inherently dehumanising and preventable deaths are inevitable, then the problem that must be addressed is the prison itself. As long as the prison remains, it will be a factory of misery and death. To mourn the death of the prisoner, we must undo the structures that kill them. We must abolish the prison.

However, prison abolition is not enough. The prison emerges in a setting of settler-colonial capitalism in which norms distribute heightened vulnerability and precarity to bodies both within and outside the prison. This means the problems I raise in this thesis represent just some of the dehumanising and exploitative treatment of people in this social system. For this reason, the abolition of prisons does not merely entail the absence of imprisonment. It requires a 'constellation of alternative strategies and institutions' (Davis 2003, 107). These alternatives involve the creation of social conditions of support that do not drive people toward harmful behaviour, as well as a mode of production that does not necessitate the exploitation of the many by the few.

The death of the prisoner is so intrinsic to this social system of simultaneous abundance, obscene wealth, immiseration, and dispossession that the death cannot be mourned within a system that necessitates it. The prison itself is so necessary to the capitalist mode of production that it cannot be abolished without a movement beyond settler-colonial capitalism. In this sense, we cannot mourn the death of the prisoner as long as we produce social conditions that enable it. However, these social conditions will only exist as long as we continue to reproduce them. If we choose to, we can, in time, mourn the death of the prisoner. 


\section{Appendix 1: List of Coroners' Findings}

\section{Excluded cases:}

Crerar, Coroner David. 2015. 'Findings in the Matter of Boyd Edward Cuttance.' CSU-2012DUN-000139. Dunedin: Coroner's Court.

Matenga, Coroner Gordon. 2012. 'Findings in the Matter of Jason Clint Martin Palmer.' CSU-2010-AUK-000619. Hamilton: Coroner's Court

- 2015. 'Findings in the Matter of Paul Philip Wilson.' CSU-2011-WGN-000189. Hamilton: Coroner's Court.

Ryan, Coroner JP. 2014. 'Findings in the Matter of Michael George Worth.' CSU-2013ROT-000218. Hamilton: Coroner's Court.

Smith, Coroner Ian. 2013. 'Findings in the Matter of Richard Paul Wos.' CSU-2010-WGN000496. Wellington: Coroner's Court.

\section{Natural cause of death:}

Bain, Coroner Wallace. 2010. 'Findings in the Matter of Lance Michael Porteous.' CSU2009-ROT-000355. Rotorua: Coroner's Court.

- 2012. 'Findings in the Matter of James Ara Kataina.' CSU-2011-ROT-000329. Rotorua: Coroner's Court.

- 2014. 'Findings in the Matter of David John Elliot.' CSU-2013-HAM-000014. Rotorua: Coroner's Court.

- 2014. 'Findings in the Matter of Paraire Pouterata.' CSU-2013-ROT-000166. Rotorua: Coroner's Court.

Crerar, Coroner David. 2012. 'Findings in the Matter of Michael Lyndsay Grant.' CSU-2011DUN-000173. Dunedin: Coroner's Court.

- 2012. 'Findings in the Matter of Allan James Cowley.' CSU-2011-DUN-000252. Dunedin: Coroner's Court.

- 2012. 'Findings in the Matter of Michael Joseph Anthony Carroll.' CSU-2012-DUN000033. Dunedin: Coroner's Court.

Devonport, Coroner Christopher. 2011. 'Findings in the Matter of Albert John Watson.' CSU-2011-CCH-000675. Hastings: Coroner's Court.

- 2015. 'Findings in the Matter of Robert Paul Cook.' CSU-2014-CCH-000243. Hastings: Coroner's Court.

Evans, Coroner Garry. 2011. 'Findings in the Matter of Albena Atanasova Zareva.' CSU2010-WGN-000158. Wellington: Coroner's Court.

- 2012. 'Findings in the Matter of Rodney Rata Kauhau.' CSU-2011-WGN-000385. Wellington: Coroner's Court.

- 2015. 'Findings in the Matter of Rex Charles Anson.' CSU-2014-WGN-000362. Wellington: Coroner's Court.

Greig, Coroner Katharine. 2010. 'Findings in the Matter of Phat Vongphakdy.' CSU-2008AUK-001757. Auckland: Coroner's Court. . 2011. 'Findings in the Matter of Ikitala Tulisi'. CSU-2009-AUK-000966. Auckland: Coroner's Court. 
. 2012. 'Findings in the Matter of Anna Selina Kingi.' CSU-2008-AUK-001671.

Auckland: Coroner's Court.

. 2011. 'Findings in the Matter of Riki John Pairama.' CSU-2009-AUK-001451.

Auckland: Coroner's Court.

. 2014. 'Findings in the Matter of Helen Lillian Climo.' CSU-2014-AUK-000075.

Auckland: Coroner's Court.

Herdson, Coroner Sarn. 2015. 'Findings in the Matter of David Konia'. CSU-2015-PNO000020. Coroner's Court.

- 2015. 'Findings in the Matter of Thomas Clyde Parrish.' CSU-2015-WHG-000095. Auckland: Coroner's Court.

Jamieson, Coroner Murray. 2009. 'Findings in the Matter of Gaileen Margaret Codlin.' CSU2008-AUK-000126. Auckland: Coroner's Court.

- 2010. 'Findings in the Matter of Colin Milson Gough.' CSU-2009-AUK-001129. Auckland: Coroner's Court.

- 2011. 'Findings in the Matter of Duncan Conrad Murray Frost.' CSU-2010-AUK000884. Auckland: Coroner's Court.

Johnson, Coroner Sue. 2008. 'Findings in the Matter of Adrian Harding Olson.' CSU-2009$\mathrm{CCH}-000153$. Christchurch: Coroner's Court.

- 2008. 'Findings in the Matter of Stephen Murray Calcinai.' CSU-2008-CCH000064. Christchurch: Coroner's Court.

- 2015. 'Findings in the Matter of Kevin Arthur Thompson.' CSU-2012-CCH-00947. Christchurch: Coroner's Court.

Matenga, Coroner Gordon. 2009. 'Findings in the Matter of Charlie Henry Ruwhiu.' CSU2009-HAM-000280. Hamilton: Coroner's Court.

- 2009. 'Findings in the Matter of Raymond Charles Pearson.' CSU-2009-HAM000301. Hamilton: Coroner's Court.

- 2009. 'Findings in the Matter of Dion Graham Rawiri.' CSU-2009-HAM-000388. Hamilton: Coroner's Court.

. 2009. 'Findings in the Matter of Dennis Hines.' CSU-2009-HAM-000493. Hamilton: Coroner's Court.

. 2012. 'Findings in the Matter of Arthur Waretini.' CSU-2012-HAM-000094.

Hamilton: Coroner's Court.

- 2012. 'Findings in the Matter of Arthur Penaia Teo.' CSU-2012-HAM-000135.

Hamilton: Coroner's Court.

- 2015. 'Findings in the Matter of James Henare Heta.' CSU-2013-ROT-000376. Hamilton: Coroner's Court.

- 2015. 'Findings in the Matter of Adrian Vincent Martin.' CSU-2015-HAM-000173. Hamilton: Coroner's Court.

McDowell, Coroner Morag. 2010. 'Findings in the Matter of Liufono Vilikeka.' CSU-2009AUK-001433. Auckland: Coroner's Court. . 2014. 'Findings in the Matter of Finao Joe Ah Chong.' CSU-2012-WHG-000261. Auckland: Coroner's Court. . 2014. 'Findings in the Matter of Brian Wilfred Fox.' CSU-2014-AUK-001109. Auckland: Coroner's Court.

McElrea, Coroner Richard. 2009. 'Findings in the Matter of Christopher Francis Pinker.' CSU-2009-CCH-000876. Christchurch: Coroner's Court.

_. 2011. 'Findings in the Matter of Wayne John Panapa.' CSU-2010-CCH-000589. Christchurch: Coroner's Court.

- 2011. 'Findings in the Matter of Kevin Moana Jarden.' CSU-2010-CCH-000789. Christchurch: Coroner's Court. 
2013. 'Findings in the Matter of Stephen Edward Wells.' CSU-2012-CCH-000546. Christchurch: Coroner's Court.

2014. 'Findings in the Matter of Charles Alfred Martin Cunningham.' CSU-2013CCH-000589. Christchurch: Coroner's Court.

. 2014. 'Findings in the Matter of Louis Ariki Te Moananui.' CSU-2013-CCH-

000603. Christchurch: Coroner's Court.

Nagara, Coroner Carla na. 2008. 'Findings in the Matter of James Koteraki Kahu.' CSU2009-PNO-000175. Palmerston North: Coroner's Court.

. 2011. 'Findings in the Matter of Rufus Marsh.' CSU-2010-PNO-000006. Palmerston North: Coroner's Court.

. 2011. 'Findings in the Matter of David Francis White.' CSU-2010-PNO-000491.

Palmerston North: Coroner's Court.

_ 2016. 'Findings in the Matter of Saomalie George Toailoa.' CSU-2014-WGN000044. Palmerston North: Coroner's Court.

Ryan, Coroner JP. 2013. 'Findings in the Matter of Maxwell John Heslehurst.' CSU-2012-

HAM-000395. Hamilton: Coroner's Court.

. 2013. 'Findings in the Matter of Alan John Jamieson.' CSU-2012-HAM-000576.

Hamilton: Coroner's Court.

Scott, Coroner Tim. 2008. 'Findings in the Matter of John David Fleming.' CSU-2008-PNO000422. Palmerston North: Coroner's Court.

. 2008. 'Findings in the Matter of Alan John Luce.' CSU-2008-PNO-000069.

Palmerston North: Coroner's Court.

. 2012. 'Findings in the Matter of Miller Glenn Joseph Haapu.' CSU-2012-PNO000067. Palmerston North: Coroner's Court.

. 2013. 'Findings in the Matter of [Name Redacted].' CSU-2011-PNO-000311.

Palmerston North: Coroner's Court.

- 2016. 'Findings in the Matter of Donald Bryan Liddington.' CSU-2015-WGN000444. Palmerston North: Coroner's Court.

. 2016. 'Findings in the Matter of William James Bayne.' CSU-2016-WGN-000176.

Palmerston North: Coroner's Court.

Shortland, Coroner Brandt. 2011. 'Findings in the Matter of Philip Nelson.' CSU-2008WHG-000326. Whangarei: Coroner's Court.

2011. 'Findings in the Matter of George Herbert.' CSU-2009-WHG-000061.

Whangarei: Coroner's Court.

2011. 'Findings in the Matter of Colin Richard Warren.' CSU-2010-WHG-000166. Whangarei: Coroner's Court.

Smith, Coroner Ian. 2009. 'Findings in the Matter of Genesis Phillip Smith.' CSU-2008WGN-000739. Wellington: Coroner's Court . 2010. 'Findings in the Matter of Lawrence Neville Turner.' CSU-2009-WGN000090. Wellington: Coroner's Court.

. 2011. 'Findings in the Matter of Jeffrey Joseph Driver.' CSU-2010-WGN-000483.

Wellington: Coroner's Court.

. 2012. 'Findings in the Matter of John Alexander Taylor.' CSU-2011-WGN-000091.

Wellington: Coroner's Court.

. 2014. 'Findings in the Matter of Aaron James McDowell.' CSU-2011-WGN-

000167. Wellington: Coroner's Court.

. 2014. 'Findings in the Matter of Joseph Wayne John Craig Berry.' CSU-2013-PNO000379. Wellington: Coroner's Court.

. 2014. 'Findings in the Matter of Brian Frederick Scott.' CSU-2013-WGN-000413.

Wellington: Coroner's Court. 
. 2014. 'Findings in the Matter of Sio Kalolo.' CSU-2013-PNO-000602. Wellington: Coroner's Court.

Windley, Coroner Brigitte. 2016. 'Findings in the Matter of Warwick Bruce Couchman.' CSU-2016-CCH-000231. Dunedin: Coroner’s Court.

\section{Ambiguous cause of death:}

Matenga, Coroner Gordon. 2011. 'Findings in the Matter of Clifton Robert Reilly.' CSU2009-HAM-000654. Hamilton: Coroner's Court.

\section{Section 74 case:}

Scott, Coroner Tim. 2013. 'Findings in the Matter of [Name Redacted].' CSU-2012-PNO000280. Palmerston North: Coroner's Court.

\section{Unnatural cause of death - non-self-inflicted:}

Crerar, Coroner David. 2015. 'Findings in the Matter of Jai Gordon Davis.' CSU-2011-DUN000065. Dunedin: Coroner's Court.

McDowell, Coroner Morag. 2015. 'Findings in the Matter of Tue Fa'avae.' CSU-2009-AUK000356. Auckland: Coroner's Court.

Ryan, Coroner JP. 2012. 'Findings in the Matter of Nicholas Ward Harris.' CSU-2011-HAM000020. Hamilton: Coroner's Court.

Unnatural cause of death - self-inflicted - non- $§ 71$ cases

Crerar, Coroner David. 2012. 'Findings in the Matter of Richard John Barriball.' CSU-2010DUN-000364. Dunedin: Coroner's Court.

Devonport, Coroner Christopher. 2010. 'Findings in the Matter of Dallas James Pettigrew.' CSU-2009-CCH-001024. Hastings: Coroner's Court.

- 2010. 'Findings in the Matter of Daniel Joshua Kipling Barry.' CSU-2008-CCH000962. Hastings: Coroner's Court.

- 2012. 'Findings in the Matter of Zachariah Beaudine Tangohau.' CSU-2010-CCH000548. Hastings: Coroner's Court.

- 2015. 'Findings in the Matter of Bradley Steven Twidle.' CSU-2013-CCH-000690. Hastings: Coroner's Court.

Evans, Coroner Garry. 2013. 'Findings in the Matter of Antoine Roni Dixon.' CSU-2009AUK-000201. Wellington: Coroner's Court. . 2015. 'Findings in the Matter of Tipene Dawson Pomare (Aka Dawson Te Huna).' CSU-2014-WGN-000293. Wellington: Coroner's Court. 
Greig, Coroner Katharine. 2012. 'Findings in the Matter of Glenn Richard Albert Mills.' CSU-2009-AUK-001614. Auckland: Coroner's Court.

McDowell, Coroner Morag. 2009. 'Findings in the Matter of Casey David Stephen Voges.' CSU-2008-AUK-000047. Auckland: Coroner's Court.

- 2014. 'Findings in the Matter of Tony Allan Worrell.' CSU-2011-AUK-000330. Auckland: Coroner's Court.

McElrea, Coroner Richard. 2012. 'Findings in the Matter of Hurikino Dennis Luke.' CSU2011-CCH-000030. Christchurch: Coroner's Court.

Nagara, Coroner Carla na. 2011. 'Findings in the Matter of Taffy Herbert Hotene.' CSU2009-PNO-000594. Palmerston North: Coroner's Court.

Scott, Coroner Tim. 2012. 'Findings in the Matter of [Name Redacted].' CSU-2010-PNO000157. Palmerston North: Coroner's Court.

_. 2012. 'Findings in the Matter of Donald Gisborne.' CSU-2011-PNO-00001 3. Palmerston North: Coroner's Court. . 2012. 'Findings in the Matter of [Name Redacted].' CSU-2011-PNO-000228. Palmerston North: Coroner's Court. . 2016. 'Findings in the Matter of David Mark Crosland.' CSU-2014-HAM-000540. Palmerston North: Coroner's Court.

\section{Unnatural cause of death - self-inflicted -71 cases:}

Bell, Coroner Debra. 2016. 'Findings in the Matter of Morgan Wayne Knight.' CSU-2015AUK-000051. Auckland: Coroner's Court.

Crerar, Coroner David. 2011. 'Findings in the Matter of Kurt Christopher Peter Graham.' CSU-2010-DUN-000220. Dunedin: Coroner's Court.

Devonport, Coroner Christopher. 2011. 'Findings in the Matter of Michael Graham Maxwell.' CSU-2009-CCH-000987. Hastings: Coroner's Court. . 2012. 'Findings in the Matter of Barry Alan Ryder.' CSU-2012-HAS-000017. Hastings: Coroner's Court. . 2015. 'Findings in the Matter of Daniel Rangihaea Skipper.' CSU-2014-WGN000253. Hastings: Coroner's Court.

Jamieson, Coroner Murray. 2008. 'Findings in the Matter of Mark Te'o.' CSU-2008-AUK000510. Auckland: Coroner's Court.

- 2009. 'Findings in the Matter of Alec Imtiaz Ali.' CSU-2008-AUK-000106. Auckland: Coroner's Court.

- 2010. 'Findings in the Matter of Derrol Wayne Primrose.' CSU-2008-AUK-000702. Auckland: Coroner's Court.

Matenga, Coroner Gordon. 2008. 'Findings in the Matter of Andrew Douglas Mokofisi.' CSU-2008-HAM-000171. Hamilton: Coroner's Court.

- 2012. 'Findings in the Matter of Michael John Thompson.' CSU-2010-HAM000585. Hamilton: Coroner's Court.

Nagara, Coroner Carla na. 2010. 'Findings in the Matter of Murray George Hepi.' CSU-2009PNO-000292. Palmerston North: Coroner's Court.

- 2013. 'Findings in the Matter of William John Lawrence.' CSU-2011-PNO-000515. Palmerston North: Coroner's Court.

Ryan, Coroner JP. 2012. 'Findings in the Matter of Garrett Te Ao Marama Rawiri.' CSU2011-HAM-000172. Hamilton: Coroner's Court. 
- 2013. 'Findings in the Matter of Rajwinder Singh.' CSU-2013-HAM-000047. Hamilton: Coroner's Court.

. 2016. 'Findings in the Matter of Rowan Joseph Smart Edwards.' CSU-2014-DUN000252. Wellington: Coroner's Court.

Shortland, Coroner Brandt. 2011. 'Findings in the Matter of Toby Lea Shelton Also Known as Gregory Karl Reed.' CSU-2010-WHG-000186. Whangarei: Coroner's Court.

—. 2013. 'Findings in the Matter of George Little.' CSU-2012-WHG-000045. Whangarei: Coroner's Court.

- 2014. 'Findings in the Matter of Eruera Henare Murray.' CSU-2011-WHG-000125. Whangarei: Coroner's Court.

. 2016. 'Findings in the Matter of Joshua Mark William Tryselaar.' CSU-2014-AUK000626. Whangarei: Coroner's Court.

Smith, Coroner Ian. 2012. 'Findings in the Matter of Kerry Norman Joll.' CSU-2011-WGN000238. Wellington: Coroner's Court.

Tutton, Coroner Anna. 2016. 'Findings in the Matter of Adeline Kate Rogers.' CSU-2013CCH-000209. Christchurch: Coroner's Court. 


\section{Reference List}

Ainsworth, Susan, and Cynthia Hardy. 2004. 'Critical Discourse Analysis and Identity: Why Bother?' Critical Discourse Studies 1 (2): 225-59.

Althusser, Louis. 2001. Lenin and Philosophy and Other Essays. Translated by Ben Brewster. New York: Monthly Review Press.

Anasseril, E. Daniel, and Jennifer Fleming. 2006. 'Suicides in a State Correctional System, 1992-2002: A Review'. Journal of Correctional Health Care 12 (1): 24-35.

Andrews, Jackie. 2017. 'RE: Letter to the Chief Coroner Pertaining to S 71A Exemption', March 23. Email to Ti Lamusse.

Arbuckle, Vincent. 2017a. 'Prison Inspector's Report into Death of Nicholas Ward Harris (Official Information Act Request)', May 3. Letter to Ti Lamusse.

. 2017b. 'Reducing Reoffending Through Employment -- Presentation by Elizabeth Manchee (Official Information Act Response to Ti Lamusse)'. Fyi.org.nz. August 11. https://fyi.org.nz/request/6290/response/21095/attach/9/Correspondence\%20from\%20 Corrections\%20C87697.pdf.

Baez, Joan. 1972. 'Prison Trilogy (Billy Rose)'. In Come from the Shadows. Nashville: A\&M. Bakker, Leon, Stephen Hudson, David Wales, and David Riley. 2000. 'And There Was Light ... Evaluating the Kia Marama Treatment Programme for New Zealand Sex Offenders Against Children'. Wellington: Department of Corrections.

Beckett, Clare. 1999. 'Deaths in Custody and the Inquest System'. Critical Social Policy 19 (2): 271-280.

Belich, James. 2015. The New Zealand Wars and the Victorian Interpretation of Racial Conflict. Auckland: Auckland University Press.

Biddle, Donna-Lee. 2016. 'Cash Injection to Save Prisoners' Lives'. Stuff. November 2. http://www.stuff.co.nz/national/health/85920162/cash-injection-to-save-prisonerslives.

Boshier, Peter. 2016a. 'COTA Report: Report on an Unannounced Inspection of Corrections Service Invercargill Prison Under the Crimes of Torture Act 1989'. Wellington: Office of the Ombudsman.

- 2016b. 'COTA Report: Report on an Unannounced Inspection of Corrections Service Manawatu Prison Under the Crimes of Torture Act 1989'. Wellington: Office of the Ombudsman.

- 2016c. 'COTA Report: Report on an Unannounced Inspection of Corrections Service Otago Corrections Facility Under the Crimes of Torture Act 1989'. Wellington: Office of the Ombudsman.

—. 2017a. 'OPCAT Findings Report: A Question of Restraint'. Wellington: Office of the Ombudsman.

—. 2017b. 'OPCAT Report: Report on an Unannounced Inspection of Hawke's Bay Regional Prison Under the Crimes of Torture Act 1989'. Wellington: Office of the Ombudsman.

- 2017c. 'OPCAT Report: Report on an Unannounced Inspection of Spring Hill Corrections Facility Under the Crimes of Torture Act 1989'. Wellington: Office of the Ombudsman.

Brooking, Roger. 2012. 'Officers "justified" in Suffocating Suicidal Prisoner to Death - the Case of Nicholas Harris'. Brookingblog. December 19. https://brookingblog.com/2012/12/19/officers-justified-in-suffocating-suicidalprisoner-to-death-the-case-of-nicholas-harris/.

Butler, Judith. 1997a. Excitable Speech: A Politics of the Performative. New York: Routledge. 
1997b. The Psychic Life of Power: Theories in Subjection. Stanford: Stanford University Press.

2000. Antigone's Claim: Kinship between Life and Death. New York: Columbia University Press.

- 2004. Undoing Gender. New York: Routledge.

- 2005. Giving an Account of Oneself. New York: Fordham University Press.

- 2006a. Gender Trouble: Feminism and the Subversion of Identity. New York: Routledge.

- 2006b. Precarious Life: The Powers of Mourning and Violence. New York: Verso.

- 2010. Frames of War: When Is Life Grievable? New York: Verso.

- 2011. Bodies That Matter: On the Discursive Limits of 'Sex'. New York: Routledge.

- 2012a. Parting Ways: Jewishness and the Critique of Zionism. New York: Columbia University Press.

—. 2012b. Subjects of Desire: Hegelian Reflections in Twentieth-Century France. New York: Columbia University Press.

- 2015a. Notes toward a Performative Theory of Assembly. Cambridge, MA: Harvard University Press.

- 2015b. Senses of the Subject. New York: Fordham University Press.

Butler, Judith, and Athena Athanasiou. 2013. Dispossession: The Performative in the Political. Malden, MA: Polity.

Butler, Judith, and Gayatri Chakravorty Spivak. 2007. Who Sings the Nation-State? Language, Politics, Belonging. London: Seagull.

Chiapello, Eve, and Norman Fairclough. 2010. 'Understanding the New Management Ideology. A Transdisciplinary Contribution from Critical Discourse Analysis and the New Sociology of Capitalism'. In Critical Discourse Analysis: The Critical Study of Language, 2nd ed., 255-80. Harlow: Pearson.

Coroners Act. 2006.

Coronial Services. 2016a. 'Natural \& Unnatural Deaths'. Coronial Services of New Zealand. June 22. https://coronialservices.justice.govt.nz/what-to-expect-during-aninquiry/natural-and-unnatural-deaths/.

- 2016b. 'Hearings \& Inquests'. Coronial Services of New Zealand. October 26. https://coronialservices.justice.govt.nz/what-to-expect-during-an-inquiry/get-helpafter-someone-dies/.

Corrections Act. 2004.

Cox, Brian, and Keren Skegg. 1993a. 'Contagious Suicide in Prisons and Police Cells.' Journal of Epidemiology and Community Health 47 (1): 69-72.

—. 1993b. 'Suicide in Custody: Occurrence in Māori and Non-Māori New Zealanders'. NZ Medical Journal, no. 106: 1-4.

Crerar, Coroner David. 2011. 'Findings in the Matter of Kurt Christopher Peter Graham'. CSU2010-DUN-000220. Dunedin: Coroner's Court.

_. 2012a. 'Findings in the Matter of Richard John Barriball'. CSU-2010-DUN-000364. Dunedin: Coroner's Court.

—. 2012b. 'Findings in the Matter of Michael Lyndsay Grant'. CSU-2011-DUN-000173. Dunedin: Coroner's Court.

- 2015. 'Findings in the Matter of Jai Gordon Davis'. CSU-2011-DUN-000065. Dunedin: Coroner's Court.

Davis, Angela. 2003. Are Prisons Obsolete? New York: Seven Stories.

Department of Corrections. 2001. 'Inmate Employment Policy'. Wellington: Department of Corrections. 
—. 2008. 'Annual Report: 1 July 2007 - 30 June 2008'. Wellington: Department of Corrections.

2009. 'Annual Report: 1 July 2008 - 30 June 2009'. Wellington: Department of Corrections.

. 2010. 'Annual Report: 1 July 2009 - 30 June 2010'. Wellington: Department of Corrections.

—. 2011. 'Annual Report: 1 July 2010 - 30 June 2011'. Wellington: Department of Corrections.

—. 2012. 'Annual Report: 1 July 2011 - 30 June 2012'. Wellington: Department of Corrections.

—. 2013. 'Annual Report: 1 July 2012 - 30 June 2013'. Wellington: Department of Corrections.

—. 2014. 'Annual Report: 1 July 2013 - 30 June 2014'. Wellington: Department of Corrections.

—. 2015. 'Annual Report: 1 July 2014 - 30 June 2015'. Wellington: Department of Corrections.

. 2016a. 'Annual Report: 1 July 2015 - 30 June 2016'. Wellington: Department of Corrections.

- 2016b. 'Briefing to the Incoming Minister December 2016'. Wellington: Department of Corrections.

—. 2016c. 'Corrections Works March 2016'. Wellington: Department of Corrections.

. 2016d. 'Health Care'. Department of Corrections. December 4. http://www.corrections.govt.nz/working_with_offenders/prison_sentences/being_in_p rison/health_care.html.

—. 2017a. 'Prison Facts and Statistics - December 2016'. Department of Corrections. January

http://www.corrections.govt.nz/resources/research_and_statistics/quarterly_prison_sta tistics/prison_stats_december_2016.html.

- 2017b. 'Prison Statistics'. Department of Corrections. July 18. http://www.corrections.govt.nz/resources/research_and_statistics/quarterly_prison_sta tistics.html.

Department of Corrections, and Ministry of Health. 2008. 'Memorandum of Understanding on the Management of Prisoners Requiring Secondary Mental Health Services and Hospital Level Care'. Wellington.

Derrida, Jacques. 1988. 'Signature Event Context'. In Limited Inc, translated by Samuel Weber and Jeffrey Mehlman, 1-24. Evanston, IL: Northwestern University Press.

Devonport, Coroner Christopher. 2010a. 'Findings in the Matter of Dallas James Pettigrew'. CSU-2009-CCH-001024. Hastings: Coroner's Court.

—. 2010b. 'Findings in the Matter of Daniel Joshua Kipling Barry'. CSU-2008-CCH000962. Hastings: Coroner's Court.

- 2011. 'Findings in the Matter of Michael Graham Maxwell'. CSU-2009-CCH-000987. Hastings: Coroner's Court.

- 2012a. 'Findings in the Matter of Zachariah Beaudine Tangohau'. CSU-2010-CCH000548. Hastings: Coroner's Court.

- 2012b. 'Findings in the Matter of Barry Alan Ryder'. CSU-2012-HAS-000017. Hastings: Coroner's Court.

—. 2015a. 'Findings in the Matter of Bradley Steven Twidle'. CSU-2013-CCH-000690. Hastings: Coroner's Court.

2015b. 'Findings in the Matter of Daniel Rangihaea Skipper'. CSU-2014-WGN000253. Hastings: Coroner's Court. 
Dewing, Suraya Francése. 2013. 'Women Among Men: Human Rights Jurisprudence and PreOperative Male-to-Female Transgender Imprisonment'. Master of Arts Thesis, Auckland: University of Auckland.

Erueti, Andrew. 2004. 'Maori Customary Law and Land Tenure: An Analysis'. In Maori Land Law, edited by Richard Boast, Andrew Erueti, Doug McPhail, and Norman Smith, 2nded., 41-63. Wellington: Butterworths.

Evans, Coroner Garry. 2012. 'Findings in the Matter of Rodney Rata Kauhau'. CSU-2011WGN-000385. Wellington: Coroner's Court.

2013. 'Findings in the Matter of Antoine Roni Dixon'. CSU-2009-AUK-000201. Wellington: Coroner's Court.

- 2015. 'Findings in the Matter of Tipene Dawson Pomare (Aka Dawson Te Huna)'. CSU-2014-WGN-000293. Wellington: Coroner's Court.

Fairclough, Norman. 2010. Critical Discourse Analysis: The Critical Study of Language. 2nd ed. Harlow: Pearson.

- 2012. 'Critical Discourse Analysis'. International Advances in Engineering and Technology 7: 452-87.

Fairclough, Norman, and Phil Graham. 2010. 'Marx as a Critical Discourse Analyst: The Genesis of a Critical Method and Its Relevance to the Critique of Global Capital'. In Critical Discourse Analysis: The Critical Study of Language, 2nd ed., 301-46. Harlow: Pearson.

Fatos, Kaba, Andrea Lewis, Sarah Glowa-Kollisch, James Hadler, David Lee, Howard Alper, Daniel Selling, et al. 2014. 'Solitary Confinement and Risk of Self-Harm Among Jail Inmates'. American Journal of Public Health 104 (3): 442-47.

Fazel, Seena, Martin Grann, Boo Kling, and Keith Hawton. 2011. 'Prison Suicide in 12 Countries: An Ecological Study of 861 Suicides during 2003-2007'. Social Psychiatry and Psychiatric Epidemiology 46 (3): 191-95.

Field, Jo. 2017. 'Memorandum of Understanding between the Department and Ministry of Health Relating to the Management of Prisoners Requiring Secondary Mental Health Services and Hospital Level Care (Official Information Act Response to Ti Lamusse)'. Fyi.org.nz. May

11. https://fyi.org.nz/request/5701/response/19353/attach/9/Response\%20C84970.pdf.

Franks, Stephen. 2011. 'More Deaths in Prison Please'. StephenFranks.co.nz. July 4. http://www.stephenfranks.co.nz/more-deaths-in-prison-please/.

Gardiner, Wira, Wharekaihua Coates, David Chaplow, Ann Motutere, Brendan Moynihan, Des Ripi, Beverley Braybrook, Karl Le Quesne, and Nancy Tozer. 1996. 'Report of the Māori Suicide Review Group: Reducing Suicide by Māori Prison Inmates’. Wellington: Department of Corrections and Te Puni Kōkiri.

Gordon, Liz, and Lesley MacGibbon. 2011. 'A Study of the Children of Prisoners: Findings from Māori Data June 2011'. Wellington: Te Puni Kōkiri.

Graham, Phil, and Allan Luke. 2011. 'Critical Discourse Analysis and Political Economy of Communication: Understanding the New Corporate Order'. Cultural Politics: An International Journal 7 (1): 103-32.

Greig, Coroner Katharine. 2010. 'Findings in the Matter of Phat Vongphakdy'. CSU-2008AUK-001757. Auckland: Coroner's Court.

2012a. 'Findings in the Matter of Anna Selina Kingi'. CSU-2008-AUK-001671. Auckland: Coroner's Court.

. 2012b. 'Findings in the Matter of Glenn Richard Albert Mills'. CSU-2009-AUK001614. Auckland: Coroner's Court. 
Harris, Alexis. 2015. 'Care-Oriented Practice in At-Risk Units: Risks, Realities and Therole of Multi-Disciplinary Teams'. Master of Arts Thesis, Wellington: Victoria University of Wellington.

Hayes, Lindsay. 1995. 'Prison Suicide: An Overview and Guide to Prevention'. Mansfield, MA: National Center on Institutions and Alternatives.

'In Honour of Nicholas Ward Harris'. 2017. Facebook. Accessed July 22. https://www.facebook.com/In-honour-of-nicholas-ward-harris-200431313316885/.

Jamieson, Coroner Murray. 2008. 'Findings in the Matter of Mark Te'o'. CSU-2008-AUK000510. Auckland: Coroner's Court.

—. 2009a. 'Findings in the Matter of Alec Imtiaz Ali'. CSU-2008-AUK-000106. Auckland: Coroner's Court.

- 2009b. 'Findings in the Matter of Gaileen Margaret Codlin'. CSU-2008-AUK-000126. Auckland: Coroner's Court.

- 2011. 'Findings in the Matter of Duncan Conrad Murray Frost'. CSU-2010-AUK000884. Auckland: Coroner's Court.

Johnston, Annaliese. 2016. 'Beyond the Prison Gate: Reoffending and Reintegration in Aotearoa New Zealand'. Auckland: The Salvation Army.

Jones, Campbell. Forthcoming. The Work of Others.

Kawharu, Merata. 2005. 'Mana and the Crown: A Marae at Orakei'. In Waitangi Revisited, edited by Michael Belgrave, Merata Kawharu, and David Williams, 2nded., 211-33. Auckland: Oxford University Press.

Kelly, Shannon. 2017a. 'Natural and Unnatural Deaths in Prison since 2007 (Official Information Act Request)', July 11. Letter to Ti Lamusse.

—. 2017b. 'All Suicides by Sex and Ethnicity since July 2007 (Official Information Act Request)', July 25. Letter to Ti Lamusse.

Kidd, Rob. 2012. 'Shouts of "Murderers" at Inquest of Jailed Gang Member'. Waikato Times, June 12. http://www.stuff.co.nz/waikato-times/news/7085151/Shouts-of-murderers-atinquest-of-jailed-gang-member.

Kopeke-Te Aho, Huriana, Sophie Morgan, Dani Pickering, Emilie Rākete, and Aaliyah Zionov. 2017. 'Prison Abolition Is a Māori Issue: The Whakapapa of Prisons in Aotearoa'. Mana Magazine, no. 135(June): 30-31.

Kress, Gunther. 1996. 'Representational Resources and the Production of Subjectivity: Questions for the Theoretical Development of Critical Discourse Analysis in a Multicultural Society'. In Texts and Practices: Readings in Critical Discourse Analysis, edited by Carmen Rosa Caldas-Coulthard and Malcolm Coulthard, 15-31. London: Routledge.

Lamusse, Ti, ed. 2017a. 'Torture in New Zealand Prisons: A Briefing'. Auckland: No Pride in Prisons Press.

— 2017b. 'One Easy Way to Reduce the Prison Population'. No Pride In Prisons. February 8. http://noprideinprisons.org.nz/post/156955285040/one-easy-way-toreduce-the-prison-population.

Lamusse, Ti, Sophie Morgan, and Emilie Rākete, eds. 2016. Abolitionist Demands: Toward the End of Prisons in Aotearoa. Auckland: No Pride in Prisons Press.

Le Quesne, Karl. 1995. 'Report of the Suicide Prevention Review Group: Review of Suicide Prevention in Prisons 1995'. Wellington: Department of Justice.

Leota, Rachel. 2017a. 'Number of People in Separates Cells (Official Information Act Response to Ti Lamusse)'. Fyi.org.nz. July 14. https://fyi.org.nz/request/5904/response/20574/attach/9/Correspondence\%20from\%20 Corrections\%20C85898.pdf. 
- 2017b. 'Compassionate Release, Broken down by Financial Year (Official Information Act Response to $\mathrm{Ti}$ Lamusse)'. Fyi.org.nz. August 16. https://fyi.org.nz/request/6289/response/21189/attach/9/Correspondence $\% 20$ from $\% 20$ corrections\%20C87694.pdf.

Lightfoot, Jeremy. 2016a. 'Number and Ethnicity of Transgender Prisoners (Official Information Act Response to Ti Lamusse)'. Fyi.org.nz. September 30. https://fyi.org.nz/request/4557/response/15066/attach/3/Ti\%20Lamusse\%20C80089\% 2093\%20C80115\%206\%20C80119\%20121\%20Response.pdf.

. 2016b. 'Deaths in Custody in New Zealand Prisons (Official Information Act Response)', October 27. Letter to Donna-Lee Biddle.

—. 2016c. 'Paremoremo (Official Information Act Response to Emmy Rākete)'. Fyi.org.nz. November 24. https://fyi.org.nz/request/4753/response/15966/attach/3/C80902\%20Response.pdf.

_ 2016d. 'Prisoners Refurbishing State Houses (Official Information Act Response to Ti Lamusse)'. Fyi.org.nz. https://fyi.org.nz/request/4752/response/16213/attach/9/Response\%20C81002.pdf. . 2017. 'Review of Directed Segregation (Official Information Act Response to Ti Lamusse)'. $\quad$ Fyi.org.nz. May 23. https://fyi.org.nz/request/5599/response/19607/attach/9/Correspondence\%20from\%20 Corrections\%20C85224.PDF.pdf.

Luke, Allan. 1995. 'Text and Discourse in Education: An Introduction to Critical Discourse Analysis'. Review of Research in Education 21: 3-48.

MacPherson, Liz. 2016. 'Births and Deaths: Year Ended December 2015'. Wellington: Statistics New Zealand.

—. 2017. 'Māori Population Estimates: Mean Year Ended 31 December 2016 - Tables'. Wellington: Statistics New Zealand.

Marx, Karl. 1963. The Eighteenth Brumaire of Louis Bonaparte. Translated by International Publishers. 2nded. New York: International Publishers.

- 1976a. Capital: A Critique of the Political Economy, Volume 1. Translated by Ben Fowkes. London: Penguin Classics.

- 1976b. 'Theses on Feuerbach'. In Karl Marx, Frederick Engels: Collected Works 1845-1847, Volume 5, edited by Lev Churbanov, translated by W. Lough, 3-5. New York: International Publishers.

Marx, Karl, and Friedrich Engels. 1976. 'The German Ideology'. In Karl Marx, Frederick Engels: Collected Works 1845-1847, Volume 5, edited by Lev Churbanov, translated by Clemens Dutt, W. Lough, and C. P. Magill, 19-539. New York: International Publishers.

Matenga, Coroner Gordon. 2015. 'Findings in the Matter of Paul Philip Wilson'. CSU-2011WGN-000189. Hamilton: Coroner's Court.

McDowell, Coroner Morag. 2009. 'Findings in the Matter of Casey David Stephen Voges'. CSU-2008-AUK-000047. Auckland: Coroner's Court.

- 2014. 'Findings in the Matter of Tony Allan Worrell'. CSU-2011-AUK-000330. Auckland: Coroner's Court.

McElrea, Coroner Richard. 2011. 'Findings in the Matter of Kevin Moana Jarden'. CSU-2010CCH-000789. Christchurch: Coroner's Court.

- 2012. 'Findings in the Matter of Hurikino Dennis Luke'. CSU-2011-CCH-000030. Christchurch: Coroner's Court. . 2013. 'Findings in the Matter of Stephen Edward Wells'. CSU-2012-CCH-000546. Christchurch: Coroner's Court. 
McIntosh, Tracey. 2012. 'Marginalisation: A Case Study: Confinement'. In Maori and Social Issues, edited by Tracey McIntosh and Malcolm Mulholland, eBook edition, 425-57. Auckland: Huia.

McIntosh, Tracey, and Stan Coster. 2017. 'Indigenous Insider Knowledge and Prison Identity'. Counterfutures: Left Thought and Practice Aotearoa, no. 3: 69-100.

McKenna, Bernard. 2004. 'Critical Discourse Studies: Where to from Here?' Critical Discourse Studies 1 (1): 9-39.

Mikaere, Ani. 2005. 'The Treaty of Waitangi and Recognition of Tikanga Maori'. In Waitangi Revisited, edited by Michael Belgrave, Merata Kawharu, and David Williams, 2nded., 330-47. Auckland: Oxford University Press.

- 2011. Colonising Myths - Māori Realities: He Rukuruku Whakaaro. Wellington: Huia. Mills, C. Wright. 2000. The Sociological Imagination. New York: Oxford University Press.

Ministry of Health. 2011. 'Reporting Suicide: A Resource for the Media'. Wellington: Ministry of Health.

- 2016. 'Suicide Facts: Deaths and Intentional Self-Harm Hospitalisations: 2013'. Wellington: Ministry of Health.

Mlinac, Ivana. 2016. 'Exclusion, over-Regulation and Complexities: The Effects of Parental Incarceration on Prisoners' Children and Their Families'. Masters of Arts Thesis, Auckland: University of Auckland.

Murtola, Anna-Maria. 2016. 'Consumer, Entrepreneur, Investor? Contesting Commodification and Challenging Capitalist Subjectification'. Presented at the Social Movements, Resistance and Social Change III, Victoria University of Wellington, September 2.

Nagara, Coroner Carla na. 2008. 'Findings in the Matter of James Koteraki Kahu'. CSU-2009PNO-000175. Palmerston North: Coroner's Court.

- 2011a. 'Findings in the Matter of David Francis White'. CSU-2010-PNO-000491. Palmerston North: Coroner's Court.

- 2011b. 'Findings in the Matter of Rufus Marsh'. CSU-2010-PNO-000006. Palmerston North: Coroner's Court.

- 2011c. 'Findings in the Matter of Taffy Herbert Hotene'. CSU-2009-PNO-000594. Palmerston North: Coroner's Court.

- 2016. 'Findings in the Matter of Saomalie George Toailoa'. CSU-2014-WGN-000044. Palmerston North: Coroner's Court.

National Health Committee. 2010. 'Health in Justice: Kia Piki Te Ora, Kia Tika! - Improving the Health of Prisoners and Their Families and Whānau: He Whakapiki I Te Ora O Ngā Mauhere Me Ō Rātou Whānau'. Wellington: Ministry of Health.

New Zealand Law Commission. 2014. 'Suicide Reporting'. Wellington: New Zealand Law Commission.

Office of the Ombudsman. 2014. 'Monitoring Places of Detention: Annual Report of Activities under the Optional Protocol to the Convention against Torture (OPCAT) 1 July 2013 to 30 June 2014'. Auckland: Human Rights Commission.

Official Information Act. 1982.

Ong, Su-Wuen, and Ella Lynch. 2016. 'An Exploratory Analysis into the Mortality of Offenders'. Practice: The New Zealand Corrections Journal 4 (2): 53-60.

Parenti, Christian. 2002. 'The "New" Criminal Justice System: State Repression from 1968 to 2001'. In States of Confinement: Policing, Detention, and Prisons, edited by Joy James, 303-11. New York: Palgrave.

Parole Act. 2002.

Pennington, Phil. 2016. 'Thousands of Strip Searches Unearth Few Finds'. Radio New Zealand. June 21. http://www.radionz.co.nz/news/national/306873/thousands-of-strip-searchesunearth-few-finds. 
Poata-Smith, Evan Te Ahu. 1997. 'The Political Economy of Inequality between Maori and Pakeha'. In The Political Economy of New Zealand, edited by Chris Rudd and Brian Roper. Auckland: Oxford University Press.

. 2001. 'The Political Economy of Māori Protest Politics 1968-1995: A Marxist Analysis of the Roots of Māori Oppression and the Politics of Resistance'. Doctor of Philosophy Thesis, Dunedin: University of Otago.

. 2008. 'Closing the Gaps?' In New Zealand, New Welfare, edited by Neil Hunt, Mike O'Brien, and Robert Stephens. North Shore: Cengage Learning Australia.

- 2013. 'Inequality and Māori'. In Inequality: A New Zealand Crisis, edited by Rashbrooke, Max, 148-58. Wellington: Bridget Williams Books.

Pratt, John. 2007. Penal Populism. New York: Routledge.

Rākete, Emilie, Ti Lamusse, Sophie Morgan, and Warwick Tie. 2017. 'No Pride in Prisons on Abolitionist Politics: Warwick Tie Interviews Emilie Rākete, Ti Lamusse and Sophie Morgan'. Counterfutures: Left Thought and Practice Aotearoa, no. 3: 129-48.

Razack, Sherene. 2011. 'Timely Deaths: Medicalizing the Deaths of Aboriginal People in Police Custody'. Law, Culture and the Humanities 15 (1): 1-23.

- 2015. Dying from Improvement: Inquests and Inquiries into Indigenous Deaths in Custody. Toronto: University of Toronto Press.

Reiman, Jeffrey. 2004. The Rich Get Richer and the Poor Get Prison. Boston: Pearson.

Rethinking Crime and Punishment. 2015. 'If Prisons Are a Cause of Crime, Why Not Reduce Numbers? Changing Public Attitudes to Crime and Punishment'. Smart on Crime Series Issue 3. Wellington: Robson Hanan Trust.

Ryan, Coroner JP. 2012a. 'Findings in the Matter of Garrett Te Ao Marama Rawiri'. CSU2011-HAM-000172. Hamilton: Coroner's Court.

- 2012b. 'Findings in the Matter of Nicholas Ward Harris'. CSU-2011-HAM-000020. Hamilton: Coroner's Court.

Scott, Coroner Tim. 2012a. 'Findings in the Matter of [Name Redacted]'. CSU-2010-PNO000157. Palmerston North: Coroner's Court.

. 2012b. 'Findings in the Matter of Donald Gisborne'. CSU-2011-PNO-00001 3.

Palmerston North: Coroner's Court.

. 2012c. 'Findings in the Matter of [Name Redacted]'. CSU-2011-PNO-000228.

Palmerston North: Coroner's Court.

— 2012d. 'Findings in the Matter of Miller Glenn Joseph Haapu'. CSU-2012-PNO000067. Palmerston North: Coroner's Court.

- 2013. 'Findings in the Matter of [Name Redacted]'. CSU-2011-PNO-000311. Palmerston North: Coroner's Court.

—. 2016a. 'Findings in the Matter of Donald Bryan Liddington'. CSU-2015-WGN000444. Palmerston North: Coroner's Court.

- 2016b. 'Findings in the Matter of David Mark Crosland'. CSU-2014-HAM-000540. Palmerston North: Coroner's Court.

—. 2016c. 'Findings in the Matter of William James Bayne'. CSU-2016-WGN-000176. Palmerston North: Coroner's Court.

Scraton, Phil. 2016. 'Bearing Witness to the "Pain of Others": Researching Power, Violence and Resistance in a Women's Prison'. International Journal for Crime, Justice and Social Democracy 5 (1): 5-20.

Scraton, Phil, and Kathryn Chadwick. 1986. 'Speaking Ill of the Dead: Institutionalised Responses to Deaths in Custody'. Journal of Law and Society 13 (1): 93-115.

Scraton, Phil, and Linda Moore. 2005. The Hurt inside: The Imprisonment of Women and Girls in Northern Ireland. 2nd ed. Belfast: Northern Ireland Human Rights Commission. 
Shalev, Sharon. 2017. 'Thinking Outside the Box? A Review of Seclusion and Restraint Practices in New Zealand'. Auckland: Human Rights Commission.

Shortland, Coroner Brandt. 2011. 'Findings in the Matter of Philip Nelson'. CSU-2008-WHG000326. Whangarei: Coroner's Court.

—. 2013. 'Findings in the Matter of George Little'. CSU-2012-WHG-000045. Whangarei: Coroner's Court.

- 2016. 'Findings in the Matter of Joshua Mark William Tryselaar'. CSU-2014-AUK000626. Whangarei: Coroner's Court.

Simpson, J, M Duncanson, G Oben, A Wicken, and S Gallagher. 2016. 'Child Poverty Monitor Technical Report 2016'. Dunedin: New Zealand Child and Youth Epidemiology Service, University of Otago.

Skachill, Dean. 2017. 'Prisoner Suicides since 1995 (Official Information Act Request)', June 21. Letter to Ti Lamusse.

Slater, Cameron. 2016. 'Prison Population Is at a Record High, Judith Collins Explains Why'. Whale Oil Beef Hooked. March 21. https://www.whaleoil.co.nz/2016/03/prisonpopulation-is-at-a-record-high-judith-collins-explains-why/.

Smith, Coroner Ian. 2014. 'Findings in the Matter of Brian Frederick Scott'. CSU-2013-WGN000413. Wellington: Coroner's Court.

Smith, Paula, Claire Goggin, and Paul Gendreau. 2002. 'The Effects of Prison Sentences and Intermediate Sanctions on Recidivism: General Effects and Individual Differences'. Ottawa: Public Works and Government Services Canada.

Stanley, Elizabeth. 2011. 'Human Rights and Prisons: A Review to the Human Rights Commission'. Auckland: Human Rights Commission.

- 2017. "Risk Prevention" Just Won't Wash. Torture in Prisons Is Torture, and We Need to Act Now'. The Spinoff. March 6. https://thespinoff.co.nz/society/06-032017/risk-prevention-just-wont-wash-torture-in-prisons-is-torture-and-we-need-toact-now/.

Steven, Rob. 1989. 'Culture and Identity in New Zealand: The Case of Aotearoa'. In Culture and Identity in New Zealand, edited by David Novitz and William Willmott, 21-34. Wellington: GP Books.

United Nations General Assembly, Resolution 70/175. 2015. 'The United Nations Standard Minimum Rules for the Treatment of Prisoners'. https://www.unodc.org/documents/justice-and-prison-reform/GA-

RESOLUTION/E_ebook.pdf.

Vaccarino, Franco, Niki Murray, Margie Comrie, John Franklin, and Frank Sligo. 2009. ‘A Case Study Exploring the Interconnections between Literacy, Employment and the Library in Wanganui Prison's Self-Care Units'. Palmerston North: Massey University.

Wakem, Beverley, and David McGee. 2012. 'Investigation of the Department of Corrections in Relation to the Provision, Access and Availability of Prisoner Health Services'. Wellington: Office of the Ombudsman.

Walker, Ranginui. 2004. Ka Whawhai Tonu Matou - Struggle without End. Revised Edition. North Shore: Penguin.

Weber, Adriana. 2017. "Very Extreme" Prisoner Restrained to Save Life - Corrections'. Radio New Zealand. March 2. http://www.radionz.co.nz/news/national/325663/'veryextreme'-prisoner-restrained-to-save-life-corrections.

White, Di. 2016. 'Corrections and Clarifications - Unpicking Judith Collins' Prison Number Explanations'. The Spinoff. April 4. https://thespinoff.co.nz/society/04-042016/corrections-and-clarifications-unpicking-judith-collins-prison-numberexplanations/. 
Wodak, Ruth. 2011. 'Critical Discourse Analysis'. In Continuum Companion to Discourse Analysis, edited by Ken Hyland and Brian Paltridge, 38-53. London: Continuum.

Workman, Kim, and Tracey McIntosh. 2013. 'Crime, Imprisonment and Poverty'. In Inequality: A New Zealand Crisis, edited by Rashbrooke, Max, 120-33. Wellington: Bridget Williams Books. 